108 LCAT遭伝子G30S変異の細胞発現と地域における遭伝子 類度に関する検討

金沢大学第二内科, 社会保険勝山病院*

楊 小平, 稲津明広, 小泉順二, 梶波康二, 野原淳, 堀田孝裕, 藤堂康宏, 川尻剛照, 小泉一郎*, 馬㴊 宏

【阔 我々は, 新しいミスセンス変異Gly30SerによるLCAT欠損症 一家系を報告した，G30S変異の細胞発現実験および低HDL血症例 での変異スクリーニングを行う． H PCR-overlap法にて G30S変異型 LCAT cDNAを作成し, 発現ベクターpSG5にクローニ ングした. Lipofection法にて, COS7細胞に一過性発現をさせた. 発現48h 後の培養液中のLCAT蛋白量, 活性および発現細胞内の mRNAの定量を行った. LCAT活性は高感度proteoliposome法, LCAT蛋白量はAlbers法で行った，G30S変異のスクリーニングを PvuIIによるPCR-RFLP法にて, 発端者の出身地周辺の低HDL血症 (HDL-C 35mg/dl以下) 30例で検討した. 回㥜正常型および変異型 LCAT cDNAの発現にて, Northern法で同量のmRNAが認められた が, LCAT活性は正常型 $5.3 \mathrm{nmol} / \mathrm{ml} / \mathrm{hr}$ に対して, 変異型では測定感 度以下であった。この結果はホモ接合体例の血清の不活化LCAT 蛋白の存在と一致した．G30S変異へテロ接合体は軽度の低HDL血 症を呈するが, 同地域に㧍ける他の低HDL血症30例にはG30S変異 を認めなかった。竞羁ミスセンス変異 G30Sは不活化蛋白の産生 をきたす本家系の個人的変異である.

109 コレステロール7 $\alpha$ 水酸化醉素ノックアウトマウス $\left(\right.$ Cyp $\left.7^{\prime-}\right)$ における新生児死亡

東京大学第三内科、テキサス大学サウスウェスタン 石橋 俊、Margrit Schwarz, David Russell, 山田信博、矢崎䉝雄

[目的]コレステロール7 $\alpha$ 水酸化醅( Cyp7)は胆汁酸生合成 系の律速酫素であり、胆汁酸生成のみならず肝細胞内コレス テロール代賠の要ともなる重要な䁣素であるが、これまでに、 その変異による醉素異常症は報告されていない。そこで、本 酔素のin vivoにおける意赛を知るためにノックアウトマウス を作製した。[方法]エクソン 2-4 をネオマイシン耐性通伝 子とポリAで置換するタイプのターゲティングベクターを作 製し、ES細胞にトランスフェクトして相同的組換え体を得た。 この変晎ES細胞を肧盤胚にマイクロインジェクトしてキメラ を得、更に、へテロ $\left(C y p 7^{+/}\right)$、null型の木モ接合体 $\left(C y p 7^{\prime \prime}\right)$ を得た。[結果]Cyp $7^{+/}$の表現形は正常であった。Cyp $7^{\prime \prime}$ は 出生直後は正常であるか、生後18日以内にほとんどが死亡し た。生後1日から4日の間に40\%が死亡し、生後11日から18 日の間に $45 \%$ が死亡する 2 相性の死亡曲線を示した。第 1 相 の死亡は好娠母にビタミン補給することにより抑制され、第 2 相の死亡はコール酸補充によって抑制された。これら補充 療法を施行しなかったマウスの体重增加は不良であり、体毛 の翼常、角留墙成、視力障害などが琶められた。しかし、こ れらの異常は生後3 週以内に消失し、以後順調に発充した。 [結論]コレステロール $7 \alpha$ 水酸化醉秦は新生児期の成長に不可

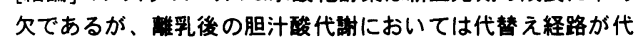
暴しうると考えられた。

\section{0 脂肪肝易発動物スンクスにおける}

肝内Microsomal Triglyceride Transfer Protein (MTP)活性について 帝京大学第一内科梁一強，金子和子，鸠津伸子，武藤朝美、 藤田美峰子、木下誠, 山中正己, 寺本民生 大阪大学第二内科 石神真人、山下静也

【目的】スンクスでは24時間の絶食後脂肪肝が誘発され、再提食に より速やかに回復する。その原因として本動物において肝内Acyl-Co A Chol esterol Acyl transferase活性が著明に低いことより、VLDLのア センブリー過程の障嗐が考えられた。一方、最近VLDLのアセンブリー における肝内Microsomal Triglyceride Transfer Protein (MTP)の役割が注 目されているそこで本研究ではスンクスの肝内MTP活性について検 討し、食事の修飾による変動についても検討を加えたので報告する。

【方法】雄性スンクスと雄性Wistar系ラットを用いて、対照群は自由 摄食、絶食群は24時間絶食後、再摄食群は24時間絶食後24時間再摄 食の条件下で飼養した。動物は麻醉下で放血屠殺し、直ちに肝蘎を 採取した。従来の方法で肝臟よりMicrosomal 分画を分離した。MTP 活性はWetterauらの方法にてliposome間の ${ }^{14} \mathrm{C}-\mathrm{TG} と^{3} \mathrm{H}-\mathrm{PC} の$ 転送率に およほすす microsomal分画の添加量から計算した。

【成績】ラットでは添加microsome蛋白を25、50、75ugとするとMTP 活性は直線的に上昇したが、スンクスでは75ugまでは転送活性が観 察されず、100ug、200ugで直線的な転送活性を示した。ラットの75 ugとスンクスの200ugがほぼ等価であったことよりスンクスではラッ 卜の約 $1 / 3$ の活性しかないことが判明した。次に、食事状態による影 響を観察したところ、ラットでは全くMTP活性に差か認められなかっ たが、スンクスでは再掑食により有意にMTP活性の上昇を見た。

【結論】スンクスではラットに比較すると肝内MTP活性が低かった。 スンクスにおいて絶食時に見られる脂肪肝はMTPの活性低下による ものではないと考えられたが、再掑食による速やかな脂肪肝の改善 にはMTP活性の上昇が関与している可能性が考えられた。

111

リポ蛋白リパーゼ(LPL)がchylomicronのCHO細胞 への結合能に及はす影響とそのメカニスムについて

千葉大学医学部第二内科

小林淳二、田代淳、村野俊一、武城英明、森崎信尋、斎藤康

目的：LPLは血中のchylomicronやVLDL中の中性脂肪を加水分解す る酵素であるが近年本酵素がリポ蛋白の細胞への結合や取り込み に関与することが示されている。今回 LDLレセプターの欠損した CHO細胞 (Idl-A7)を用いてchylomicronの結合能に及はすすLLの影響 とそのメカニズムを明らかにする。

方法 : chylomicronは健常者に $40 \mathrm{~g}$ のバターを負荷 2 時間後に採取 した血清より調整した。LPLはウシミルクより heparin-Sepharoseを 用いて精製した。125IのchylomicronへのラベリングはIC 法を用い た。125I-chylomicronのldl-A7 細胞への結合能はLPDS 含有HAM培地 にて300-500 ng/mlのLPL添加後 $4^{\circ}$ C、2 時間の結合量とした。 結果：1) LPLは125I-chylomicronのCHOへの結合能を著明に促進させ た。この促進効果はLPL醭素蛋白のC 末端を認識するモノクローナ ル抗体である5D2を添加することにより完全に抑制された。2) IdlA7細胞をあらかじめheparinaseで $37^{\circ} \mathrm{C} 1$ 時間処理すると125Ichylomicronの結合能に及ほすLPLの增強効果がheparinaseの濃度依

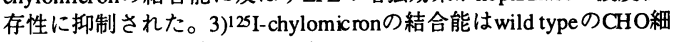
胞とldl-A7 細胞で差がなかった。

結論：以上からLPLはchylomicronのCHO細胞への結合能を著明に 促進し、これはLDLレセプターを介さず、細胞表面のヘバラン硫 酸を介したものであること、さらにこの機能にLPLのC 末端が重要 であることが示唆された。 
112 CETP欠損症における paraoxonase活性 高知医科大学第二内科 有井 薰, 末廣 正, 中内 優, 山本道也, 伊藤裕之, 池田幸雄, 森田達仁, 橋本浩三

【目的】 HDL 粒子上に apoAI と共に存在する paraoxonase (PON)は酸化LDLの生成を抑制し, HDL の動脈硬化進展阻止に重要な役割を果たしている可能 性がある.PON活性は本遺伝子多型(Gln192Arg)にも 関連している. 一方, CETP欠損症のHDLは機能的に 変化していると考えられ，今回，本欠損症における PON遺伝子多型と活性を測定した.

【方法】対象はCETP遺伝子exon15またはintron14の 異常者8例と正常CETPの健常者19例である. PON遺 伀子多型はPCR-RFLP法で同定した。PON活性は paraoxonを基質とし，测定した.

【結果】CETP 欠損症のPON遺伝子多型は全例 Gln/Argへテロ接合体であり, 以下, 対照者のへテロ 13例と比較した. CETP欠損症と対照のHDL-Cはそれ ぞれ64 (6), 59 (5) mg/dl [mean (SD)]であり有意差は なかった．PON活性はそれぞれ124（22）, 140 (15) IU/Lと差がなく，PON活性/HDL-Cもそれぞれ 2.1 (0.4), $2.4(0.3)$ と差がなかった.しかし，PON活性/ 血墏apoAIは0.62 (0.10), $0.95(0.08)$ と有意にCETP欠 損症で低下していた.

【結論】CETP欠損症のPON活性は正常者と差はなかつ た.しかし, PON活性/apoAIが低下していることから， 個々のHDL粒子のPONの作用は低下している可能性が ある. 現在, 症例を增やし検討中である.

\section{3 プラバスタチン投与による血清CETP低下作用}

金沢大学第二内科, 中外製薬診断薬事業部*

稲津明広, 小泉順二, 暒波康二, 野原淳, 堀田孝裕, 藤堂康宏, 川尻剛照，楊 小平，清原 剛*，秩父賢司*，馬渕 宏 1in プラバスタチンとプロプコール投与による血清CETP值への 影響を検討する。愿発性高コレステロール血症23例に

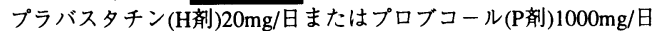
を24力月間(M)投与し, 投与前後の早朝空腹時採血にて血清脂質 を測定した。血清CETP值は，TP2mAbとrCETPに対するポリクロ ーナル抗体を用いたELISAサンドイッチ法にて測定した

盟H剂投与 11 例(M6F5, $55 \pm 2[\mathrm{SE}]$ 歳)では，CHOL前 $264 \pm 15 \mathrm{mg} / \mathrm{dl}$ に対し て $6 \mathrm{M} 224 \pm 15 \mathrm{mg} / \mathrm{dl}$ ( NS ), $24 \mathrm{M} 229 \pm 13 \mathrm{mg} / \mathrm{d}(\mathrm{p}=0.05$ ) と低 下した. HDL-C前 $49 \pm 3 \mathrm{mg} / \mathrm{dll}$ に対して $6 \mathrm{M} 51 \pm 4 \mathrm{mg} / \mathrm{dl}$ ( NS ), $24 \mathrm{M}$ $42 \pm 2 \mathrm{mg} / \mathrm{dl}(\mathrm{p}=0.06)$ と低下傾向を示した. nonHDL-C前 $215 \pm 15$ $\mathrm{mg} / \mathrm{dll}$ 対して6M $173 \pm 14 \mathrm{mg} / \mathrm{dl}(\mathrm{NS}), 24 \mathrm{M} 188 \pm 14 \mathrm{mg} / \mathrm{dl}(\mathrm{p}=0.10)$ と低下傾向を示した。血清CETP值は，前 $2.5 \pm 0.2 \mathrm{ug} / \mathrm{ml}$ に対して $6 \mathrm{M} 2.3 \pm 0.2 \mathrm{ug} / \mathrm{ml}(\mathrm{p}=0.04), 24 \mathrm{M} 2.0 \pm 0.2 \mathrm{ug} / \mathrm{ml}(\mathrm{p}=0.002)$ と著明に 低下した，P郕投与12例( M4F8, $57 \pm 4$ 歳)ではCHOL前 $236 \pm 12 \mathrm{mg} / \mathrm{dl}$ に对して6M $200 \pm 13 \mathrm{mg} / \mathrm{dl}(\mathrm{p}=0.04), 24 \mathrm{M} 210 \pm 15 \mathrm{mg} / \mathrm{dl}(\mathrm{NS})$ と低 下した. HDL-C前 $47 \pm 2 \mathrm{mg} / \mathrm{dll}$ に对し て6M 36 $\pm 2 \mathrm{mg} / \mathrm{dl}(\mathrm{p}=0.008$ ), $24 \mathrm{M} 33 \pm 2 \mathrm{mg} / \mathrm{dl}(\mathrm{p}=0.04)$ と著明に低下した。 nonHDL-C前 $189 \pm 12$ $\mathrm{mg} / \mathrm{dll}$ に対し $76 \mathrm{M} 164 \pm 12 \mathrm{mg} / \mathrm{dl}(\mathrm{p}=0.08), 24 \mathrm{M} 180 \pm 18 \mathrm{mg} / \mathrm{dl}$ ( NS ) と低下傾向を示した．血清CETP值は，前 $2.3 \pm 0.1 \mathrm{ug} / \mathrm{ml}$ に对して $6 \mathrm{M} 2.6 \pm 0.2 \mathrm{ug} / \mathrm{ml}(\mathrm{p}=0.08), 24 \mathrm{M} 2.8 \pm 0.2 \mathrm{ug} / \mathrm{ml}(\mathrm{p}=0.02)$ と增加し た. 离网プロブコールは血清CETP值を增加させるのに対して, プラバスタチンは血清CETP値を低下させる.
114

In vivo tissue selectivity of ACAT inhibitors: comparison of GF1-54 and CI-976 in mice.

Laboratoires FOURNIER: S. Perrey, T. Laugel, C. Guffroy GRELAN Pharmaceutical: H. Kasai, C. Yokomizo, A Matsuura

Acyl-CoA:cholesterol acyltransferase (ACAT), an intracellular enzyme catalyzing the esterification of cholesterol, is implicated in several aspects of lipoprotein metabolism and in atherosclerosis. Inhibition of macrophage ACAT activity is thought to have potential therapeutic application in the treatment of atherosclerosis and a number of studies have tried to show in vivo direct inhibition of macrophage ACAT. In this report, documented by in vitro selective-potency evidence, by ex vivo bioavailability and by a 4-day assay of in vivo selectivity, we demonstrate that GF1-54 exhibits higher macrophage selective ACAT inhibition than CI-976 in mice.

Each inhibitor was administered per os at $100 \mathrm{mg} / \mathrm{kg}$ for 4 days in chow-fed mice, the second day intraperitoneal macrophages were elicited by aggregated LDL and on day 4 radiolabeled cholesterol was injected in the peritoneal cavity 4 hours prior to sacrifice. In these conditions, no hypocholesterolemic effect was detectable and esterification in peritoneal macrophages was inhibited by $72.3 \% \pm 6.7$ and by $41.3 \% \pm 11.1$, respectively, by GF1-54 and CI-976. In high cholesterol diet-fed mice, while GF1-54 effected neither intestinal cholesterol absorption or liver ACAT activity, CI-976 decreased hepatic esterification of radiolabeled cholesterol by $51.5 \% \pm 17.8$ and intestinal cholesterol absorption by $51.8 \% \pm 4.5$. Even if the measurement in the liver is influenced by the chylomicron cholesterol level, we can conclude that GF1-54, compared to CI-976, is potentially a better agent for the selective targeting of macrophage ACAT inhibition rather than liver or intestinal ACAT inhibition.

\section{LDL酸化による血管平滑筋細胞のアポトーシス誘造 ープロプコール服用によるその抑制一}

東邦大学佐倉病院内科、“同臨床検査医学

戸塚光哉、宮下 洋、渡邉 仁*、村野武義 ${ }^{*}$ 、堀内美香 ${ }^{*}$

渡辺房子*、橋口正一郎、伊藤嘉晃、冨岡玖夫、白井厚治 ${ }^{*}$

【目的】我々は、コレステロール酸化生成物7-ketocholesterol が血管平滑筋細胞にアポトーシスを誘導することを 見いだし、硬化巣でcholesterol 酸化物が生成されると平 滑筋細胞が減少、内膜菲薄化か進む要因と考えている。今 回、酸化処理 L D L が平滑筋細胞にアポトーシスを誘導す る可能性と、プロブコール内服によりその作用が抑制され る可能性を検討した。

【方法】血管平滑筋細胞はヒト胃動脈からエクスプラント 法で採取、DMEM $10 \%$ 牛胎児血清下で培養し、5-6 代目を用いた。アポトーシスは、細胞剥離率、terminal deoxytransferase-mediated deoxyuridine triphosphate biotin nick end labeling (TUNEL) 法、さらにD N Aラタ ーパターンをagarose 電気泳動により確認した。プロブコ 一ル服用患者は 7 例で、服用 2 力月後採血、LDLは超迋 心法で採取、酸化は銅イオン添加で行った。

【結果】酸化 L D L を培養血管平滑筋細胞に添加すると、 24、48時間後、細胞剥離が促進された。このとき TUNEL 陽性となり、抽出D N A はラダーパターンを認め た。プロプコール服用者からの L D Lを同様に酸化処理し 平滑筋細胞に添加すると細胞剥離率は1/4 に減少、 TUNEL法でも有意の抑制が見られた。

【結論】 L D L 酸化は、血管平滑筋細胞にアポトーシスを 誘導した。プロブコール内服者から得た L D L は、酸化処 理によるアポトーシス誘導作用が抑制された。 


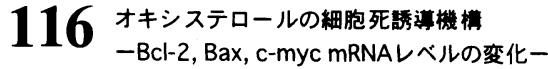

東京大学第三内科、国立小肾病院先天異常研究部

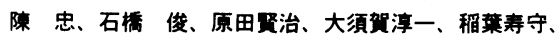

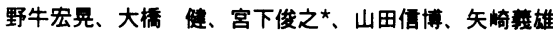

[目的]酸化LDLの成分であるオキシステロールにはアポトー シス誘算作用があり、その㤢報経路にBcl-2やInterleukin-1 $\beta$ converting enzyme (ICE) ファミリーの一員であるCPP32が 関与していることを既に報告した。今回、オキシステロール の細胞死䅎酌機序を更に明かにするためにBcl-2, Bax, c-myc mRNAレベルの变化について模时した。[方法]CMVプロモー ターを用いたヒトBCl-2の発現単位かネオマイシン耐性㯰伝子 のみを組み込んだレトロウイルスにより逶伝子些入したマク

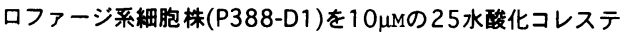
ロール存在下で培䕊し、Bcl-2, Bax, c-myc mRNAレベルの継 時的変化をノーザンブロットにより模封した。[結果]外因性 Bcl-2のmRNAは、24時間後まで增加し以後減少した。Baxの mRNAには、24時間後まで変化が珰められなかった。c-myc の mRNAは 6 時間から24時間後まで增加し以後隇少した。 Bcl-2発現細胞と非発現細胞の間にはBaxおよびc-mycの発現 パターンに差は睤められなかった。[結論]才キシステロール

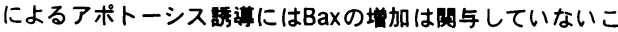
とが明かになった。また、c-myc mRNAの発現がアポトーシ スに先行して敦道され、オキシステロールの細胞墦殖作用を 仲介していると考えられた。また、Bcl-2発現調節には枟写以 後の関与の重要性が示唆された。

\section{7 助腺硬化性疾患におけるラジカル消去機構の解明}

\author{
弘前大学第二内科金瀑武道,長内智宏，鎌田孝篤，藤原直人，佐藤清彦 \\ 奥村 苝

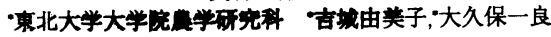

【目的】活性酸素程 $(\mathrm{X})$ とラジカル消去物質として触媒種( $(\mathrm{Y})$,受容 種 $(Z)$ との同時存在下で徽弱発光が発生し,この反応系に $|\mathrm{P}|=\mathrm{K}|\mathrm{X}| \mathrm{Y}|\mathrm{Z}|$ が成立することを吉城・大久保ら(J.Biolumin.Chemilumin.,1996)が明 らかにした。これを利用して動脈硬化性疾患におけるラジカル消去 能を解明し，過酸化低密度リポ蛋白所(POX·LDL)との成係を明らかに する。【方法】対象は心筋梗塞患者 16 例ならびに脑梗塞患者 14 例と健常者21名である。早朝空腹時の血策からリポ蛋白質を超遗 心法により分部した(VLDL: 1.006,LDL:1.007〜 1.063,HDL:1.064 $\sim 1.21$,VHDL:1.22 )。 Hydroxyradical の発生(X)は $2 \% \mathrm{H}_{2} \mathrm{O}_{2}$ と $25 \mathrm{mM}$ $\mathrm{FeCl}_{2}$ とを加えて発生させた。SampleはY系とし,Z系としては， $20 \% \mathrm{CH}_{3} \mathrm{CHO}$ 使用した。微弱発光は渡边らの方法(BBA,1991)に従 い,徽弱発光検出器CLD-110を用い, $350 \sim 160 \mathrm{~nm}$ の波長で測定され る発光の総和を求めて定量した。過酸化脂質はLPOアタミナーKit を使用しまた たydroperoxidized cholesteryl linoleate(HO-CL)は薄層ク ロマトにて定是した。

【結果】 1) 動脈硬化性疾患患者のLDL中のLPO值は健常者に比し て高値であった。HO-CL值も同粎であった。2）VLDLLDLならび にHDL中の発光量は健常者に比して患者で低值であったが、VHDL中 の発光量は両対象間で差はなかった。3) VLDL,LDL,ならびにHDL をY系とすると明らかに発光するが，X系ならびにZ系にするとほと んど発光しなかった。

【結語】リポ蛋白質はラジカル消去能を有し，鋭敏に反応している。 動脈硬化性疾患患者のLDLはより䢔酸化されており,その結果ラジカ 儿消去能は低下している。従って動脈硬化性疾患は易被過酸化の病 態にあると考えられる。
118 血中コレステロール酸化生成物の測定と検討

弘前大学医学部第三内科

村上 宏、玉沢直樹、松井 淳、須田俊宏

[目的］動脈硬化症の原因となる過酸化脂質-酸化りポ 蛋白のマーカーとして血中オキシステロール(以下OXYs) の測定法を確立し、銅イオン酸化血液にて検討した。

[方法］(I)血中OXYsの測定：血獎 2 mlに内部標準とし て5 $\alpha$-cholestan-3 $\beta, 6 \alpha$-diolを加え、Folch法にて脂質抽 出を行った。その後シリカカラムにてコレステロール をクロロフォルムでwash out L、酢酸エチルで遊離 OXYsを分離した。得られたOXYsはTMS誘導体としてガ スマスクロマト(Shimadzu GC/MS-QP5000)で定量分析を 行った。(II)本法を応用して in vitroで血獎にCuイオン を $0,0.5,1.0 \mathrm{mM}$ 加えた酸化血液にて以下の測定を行 った。(1)Cuイオン酸化血槳のOXYsの測定 (2)酸化度の指 標として、リポ蛋白のポリアクリルアミドゲル電気泳動 を行った。[結果] (1)今回のGC/MS法により $7 \alpha-7 \beta$. 7 keto-epoxy',25-hydroxy-27-hydroxy-cholesterol が良好 に分離測定された。(2)酸化血漿においては、ステロイド 環の被酸化OXYsである $7 \alpha \cdot, 7 \beta \cdot, 7$ keto-cholesterolに増加 がみられ、特に7keto-cholesterolは [Cu2+] $0 \mathrm{mM} ゙$ 平 均 $4.6 \mathrm{ng} / \mathrm{ml}, 0.5 \mathrm{mM}$ で $16.0 \mathrm{ng} / \mathrm{ml}, 1.0 \mathrm{mM}$ で 566.3 $\mathrm{ng} / \mathrm{ml}$ と著増した。(3)Cuイオンによる酸化によりLDL分 画は荷電変化による移動とともに、著しい粒子サイズの 不均一化が認められた。［結論］OXYsには細胞、血管 障害作用が報告されており、動脈硬化症の発症および進 展に梁く関わっていると考えられる。血中OXYsの測定 は、リポ蛋白コレステロール酸化度の特異的な指標と成 りうることが示唆された。

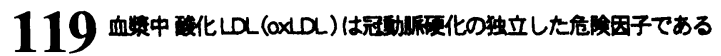

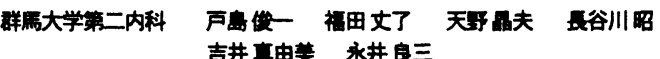

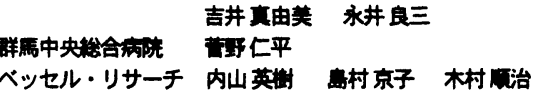

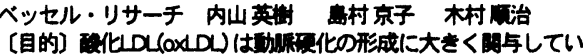
るとされている。近年、化口の棫成分で、その作用の 中心的役制を果たすとされる beo-phosphatiolicholine に対するモ

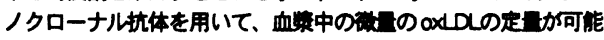

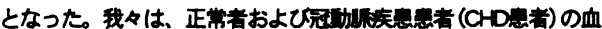

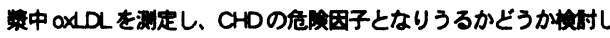

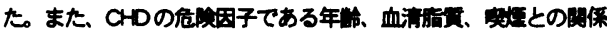
についても榯した。

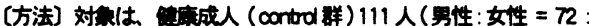

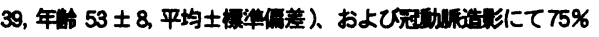

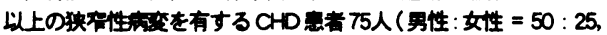

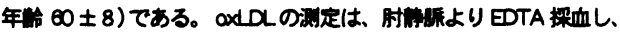

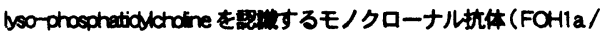

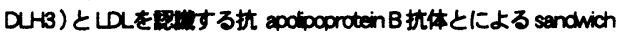
日SA法により行った。

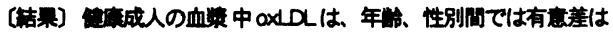

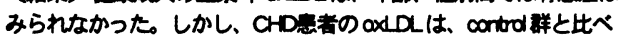

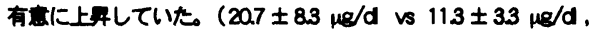

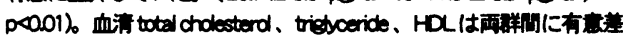

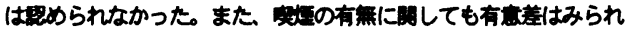
なかった(11.1 $\pm 3.5 \mu \mathrm{g} / \mathrm{d}$ vs $11.3 \pm 32 \mu \mathrm{g} / \mathrm{d}$, NS 2。

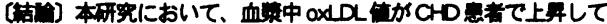

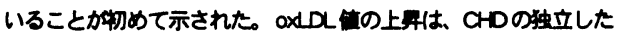
危周因子になりうると教えられる。 
120 若年heavy smoker における血小板凝集六進機序への過酸化 LDLの関与

弘前大学第二内科 金澤武道,長内智宏,今岡泰郎，森 明,木村正雄 奥村 謙

·黎明惻リハピリテーション病院・目時弘文,奥口知行

【目的】梨酒による易血管合併症の機序を解明する。

【方法】対象は24-25藏の男子学生で5年以上、1日30本以上奧㽝 している heavy smoker(HS-M)20名、同年非笑煙男子学生(NS-M) 15 名 ならびに19-20葴の非笑煙女子学生(NS-F)である。血小板凝集能は Bomらの方法に従って測定した。早朝空腹時の血箱よりLDL(1.006 $\sim 1.063 \mathrm{mg} / \mathrm{ml}$ ) 超遠心法により分画した。過酸化LDLは $5 \mu \mathrm{M}$ $\mathrm{CuCl}_{2}$ に24 時間透析して作慗した。LDLの脂質成分はBligh-Dyer法 にて脂質を抽出し、高性能薄層クロマト(HPTLC)にて分析した。 Lipid peroxide(LPO)はアタミナーKitにより測定し、また過酸化LDL は HPTLC上中性脂肪と遊離脂肪酸との中間に染色される過酸化脂 質(Spot X) を指標にして評価した。LDL中のSpot Xに関しては質量 分析計、高速液体クロマトならびに ${ }^{1} \mathrm{H} N \mathrm{NMR}$ 用いて検討した。 【結果】1）ADPならびにepinephrineによる血小板凝集能はHS-M

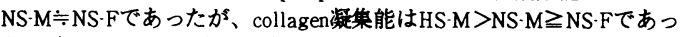
た。2）HS-MのLDLを血小板に加えるといずれの凝集惹起物質に対 しても賣集能を六進させた。3）HS-MのLDLからはSpot Xは明らか に検出されるが、NS-Mからは微量に、NS-Fからはほとんと検出さ れなかった。4）LDL中のLPO值はHS-M >NS-M ミNS-Fであった。 5） Spot Xを機器分析すると hydroperoxidized cholesteryl linoleateとその

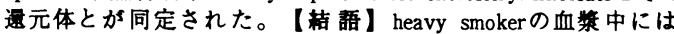
hydroperoxidized cholesteryl linoleateを持ったLDLが多く検出され、 それは血小板准集能を六進させた。従って、heavy smokerの易血管 合併病焦招来の機序に過酸化LDLの関与は大きいと考えられる。

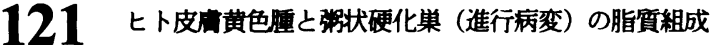

久留米大学第四内科 ${ }^{1}$ 同整形外科 ${ }^{2}$ トロント大学 ${ }^{3}$

上戸 䙾 ${ }^{1}$, 林秀樹 ${ }^{1}$ ，野中共平 ${ }^{1}$ ，小宮節郎 ${ }^{2}$, Arnis Kuksis ${ }^{3}$

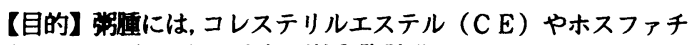
ジルコリン（P C）の多価不飽和脂肪酸がアルデヒドとなったコ アアルデヒドか存在する。今回は, 皮嵪黄色腫を分析した。症例 は, 高脂血症 (Chol378, TG157, HDL-C41ng/d1), 右躇部皮苗黄色腫 (4 x 4cn),アキレス殿黄色腫(右18mn左15m)等を有する 36 歳 男性。皮虎黄色腫はMR I $\left(T_{1}\right) て ゙$, 皮下脂肪に比し明らかな低信

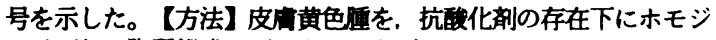
ナイズし，脂實組成はガスクロマトグラフィーで，コアアルデヒ ドは, 液体クロマトグラフィー/マススペクトロメトリーで分析

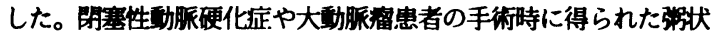
硬化巣を同様に分析した。【結果】黄色腫の脂質組成は、リン脂 兵(PC36 2.08，PC38 2.1\%，SI 1.1x); 遊碓コレステロール(Chol 8. 4X) ; コレステリルエステル (CE43 12.3X, CE45 59.0X. CE47

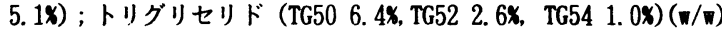
であり,組樴で泡沫細胞の集簇を認めた。㟋腫の脂質組成は， PC36

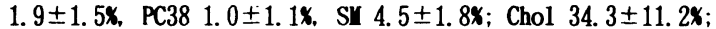

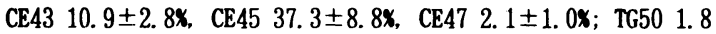
$\pm 0.9 \%, T G 524.8 \pm 2.3 \%, \quad T G 541.4 \pm 1.0 \times(M e a n \pm S D, n=8)$ であり, C Eが主の黄色腫に比し遊離コレステロールが増加し, 組織でも 䎩抱内のみならず, cholesterol cleft を呈する細抱外脂質替皘 を認めた。CEコアアルデヒドは，黄色腫にも同定されたが，犇 重に比し明らかに低値であった（C9CEコアアルデヒド/18:0ALD比

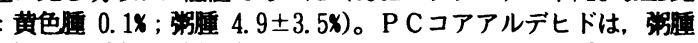
と異なり,今回の黄色腪には同定されなかった。【結論】皮蚰黄 色腫は，蕃箖脂貿の組成と部位が，岈状硬化進行病变と異なる。
122 酸化LDL に対するSuperoxide dismutaseの及ぼす影響について 1)日本大学医学部第二病理学教室、2）東京女子医科大学第一病理 学教室

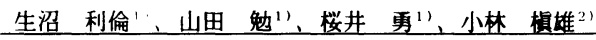

【目的】動脈硬化性病変の形成には、0xyradicals により誘導さ れた酸化LDL の種々の役割が重要とされる。今回、Oxyradicals の消去系醂素であるSuperoxide dismutase(SOD) の酸化LDL に対 する拮抗作用の有無を明らかにするため、血管平滑筋細胞培養系 を用いてSOD の及ぼす影䈏を检討した。【方法】家鬼（日本白色 種）の胸部大動脈を摘出し、単離法にて中膜平滑筋細胞を分離し 10xfetal bovine serum 添加YEY 液内で培養した。 1 ipoprotein(LDL: $\mathrm{Sigma}$ Co. ) 5 ml $\mathrm{CuSO}_{4}$ 存在下で24時間incubate し、酸化LDL を作成した $(0 \mathrm{xLDL})$ 。又、LDLを 4 ○Cで約 3 ヶ月 保存し、minimally oxidized LDL( MoLDL) とした。細胞を24穴の 思11に分け、(1)0xLDL、(2)0xLDL+SOD （ヒト赤血球Cu, Zn-SOD : Sigma Co. , 300IU )、(3)YoLDL、(4)YoLDL+SOD、(5)LDLの各群に 分けて約1-2 日間incubateした。incubation前後の細胞数より、 細胞の增殖能及び酸化LDL のcytotoxityを検討した。一方、脂質 過酸化の指標として、TBARS 法、Conjugated dine(CD) を測定し た。【結果】0xLDL 添加群では細胞数が著减する強い細胞伤害性 を示し、その現象はSOD により抑制されなかった。これに対して YoLDL は細胞を增殖させかつ遊走能を元進し、その反応はSOD に より抑制された。さらに、SOD は酸化LDL 形成を抑制する傾向に あった。SOD は主にYOLDLによってもたらされる平滑筋細胞の增 殖・遊走を抑制することにより、動脈硬化性病変形成の一過程を 制御しうることが示喛された。

123 HPLC 法を用いたWHHL ウサギ血策中の变性リポタンパク の検出

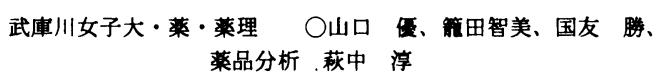

【目的】血中における変性リポタンパクの検出に関する報告は少な

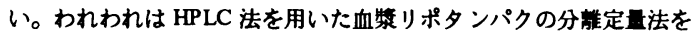
報告してきた。今回は、本法により血墏の磯化変性リポタンパク (Ox-LDL) の分敬法を確立した。それによって、自然発症高脂血症 (WHHL) ウサキののリポタンパクが正常ウサキののれと異なることを 見いだしたのて報告する。【方法】日本白色 (JW) ウサギまたは WHHL ウサギの LDLを超遠心法により分嚾、測定試料とした。昨 年本学会にて報告したアニオン交換 HPLC 法を改変し、 $\mathrm{NaCl} に よ$ ろ段階溶出法または勾配溶出法を用いて LDL と Ox-LDLを分離溶 出した。検出はポストカラム反応でコレステロールを測定すること により行った。【結果】 LDLを $\mathrm{CuCl}_{2}$ と反応させた場合、反応時間 が長くなるにつれて、LDL の変性度の指摽である遇致化脂質值の增 加及び電気泳動移㲜度の增大が梕められた。このような種々㚆性度 の異なる Ox-LDLを HPLC 法を用いて検討したところ、勾眍溶出法 では変性度に応して保持時間が長くなり、段階溶出法においても変 性度の大きいものほと溶出に高浱度の $\mathrm{NaCl}$ を必要とした。この方 法を用いて JW ウサキと WHHL ウサキの LDL の溶出パターンを比 汶したこころ、JW ウサキにに比へWHHL ウサキの LDL は、勾眍溶出 法て保持時間が長く、段陼溶出法で高湿度の $\mathrm{NaCl}$ て溶出される 分画が多くなった。また、WHHL ウサギの LDL において電気泳動

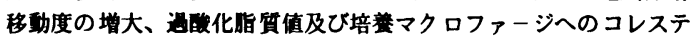

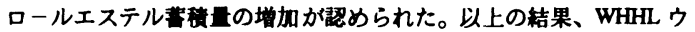
サギの血中 LDL は聎化费性していることが示唆された。 
新渴大学医学部検査診断学 岡田正彦、三井田孝、稀野浩一

【目的】低比重リホ蛋白（LDL）は、酸化によって表面権造の フラグメンテーションを起こす。酸化LDLでマウスを免疫した 際に得られる単クローン抗体とフラグメントとの反応性を調 ベ、LDLの䣬化機序と免疫学的意義について考察する。

【方法】健常者よりEDTA加探血を行ない、超逵心法およびゲ ル港過法にてLDLを精製・採取した。LDL溶液にCuSO4を加えて 䤒化反応を起こさせた。これを抗原として常法に従ってマウ スに免疫し、45種類のクローンを得た。次に、同じ酸化LDLを Superose 6でゲル誼過処理し、280nmで記録・分取を行なった。 その結果、酸化後は本来のLDL (fragment-1)とは別に、20.5〜 21nlに溶出される明瞕なピーク(fragment-2)を認めたのて、、 以下の分析に用いた。

【結果】native LDL、䤒LDL、fragment-1、fragment-2、 VLDL、HDLを用いてスクリーニングを行なった結果、反応を示 すクローン数は、それぞれ19、43、14、0、3、0であった。内、 native LDLとfragment-1に共通なクローンは14であった。

【結諭】抗原決定基は繁数に存在するため得られるクローン も偶然に左右されるが、確率睮的に以下の推諭が可能である。

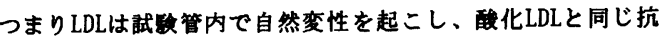
原性を㹲得する。また、酸化によって一部の抗原決定基がは ずれるが、それらはf ragment-2の分画には含まれていない。

125 過酸化条件によるLDL粒子の変形とその意義 弘前大学第二内科、“黎明郷リハビリテーション病院 渡辺 毅、金澤武道、長内智宏、小杉拓生、加藤 武、奥村 謙、 目時弘文*

[目的］ヒト血䈋中の過酸化LDLを中心に種々条件により過酸化 したLDLを比較し、過酸化LDL使用研究の適否について検討した。 [方法] 健常者の血獎LDL（ $\mathrm{n} \cdot \mathrm{LDL}$ )を、 $1 \mu \mathrm{M} \mathrm{Cu}^{2+}$ 水溶液あるいは

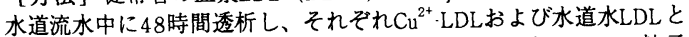
した。動脈硬化性疾患患者の血獎LDLをP.LDLとした。LDLの粒子 サイズ分布は、negative stainによる電子顕微鏡写真からプラニメー ターにて測定した。また、それぞれのLDLをゲルろ過法によっても 検討した。過酸化脂質は、デタミナーLPOキットにより測定し、ア ポタンパク質の変性はSDS.PAGEならびにアガロースゲル電気泳動 により検討した。 [結果] Negative stainkよる電子影微鏡写真に より、LDLの粒子サイズおよび形状を観察すると、n.LDLはすべて 完全な球形で、その断面積は $422.3 \pm 174.5 \mathrm{~nm}^{2}$ であった。P.LDLで は、断面積・形状ともn-LDLとほほ同様であった。一方、 $\mathrm{Cu}^{2+} \cdot \mathrm{LDL}$ では不規則な形状を示し、巨大LDL粒子片ならびに破片状の小LDL 粒子片の混在が影著であった。水道水LDLでは、 $\mathrm{Cu}^{2+} \cdot \mathrm{LDL} に$ 比べて 巨大粒子片化拉よび小粒子片化の度合いは小さかった。SDS-PAGE では、n.LDLおよびP.LDLではアポBのシングルバンドが見られるの に対し、水道水LDL および $\mathrm{Cu}^{2+}$ L LDLではアポBバンドのフラグメン テーション様変化が観察され、特にC ${ }^{2+} \cdot \mathrm{LDL} て ゙$ 著明であった。アガ ロースゲル電気泳動による移動度をみると、n.LDLとP.LDLはほほ 同じであったが、水道水LDLならびに $\mathrm{Cu}^{2+}$-LDLでは移動度は著しく

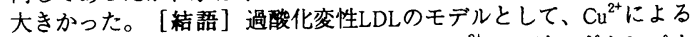

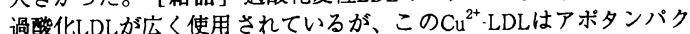
質変性が著しく、分子サイズの不均一化が著明で、生体内に存在す る過酸化LDLとは性状ならびに粒子形態か明かに異なっていた。

\section{6 血清乃ミロイド蛋白A (SAA)とHDLの反度による リ术蛋白站子の新生}

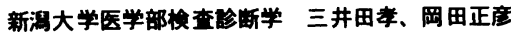
自治医科大学湢床病理学 山田俊幸

【背最】SAAは资症や急性心筋梗害で满加し、HDLに取り込まれ

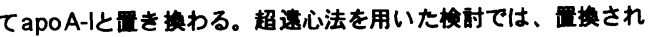
たapoA-川d d>1.210画分に存在するがその形状については不明 であるしかしSAA添加後のHDLはリン周萁かか減少しており、星

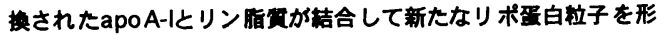
成している可能性がある。【目的】血中でのSAA满加か、新たな リポ蛋白粒子の生成を起こすか否かを明らかにする。【方法】

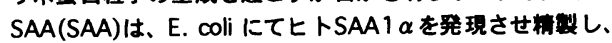
0.1 M Tris (pH 7.4), 0.05\% Tween 20に浴解して用いた。早

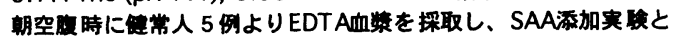
リポ蛋白の嗷に用いた。リポ蛋白はHavelらの方法を用いて分 L. $0.15 \mathrm{M} \mathrm{NaCl}, 10 \mathrm{mM}$ Tris (pH7.4), 1 mMEDTA, $0.01 \%$

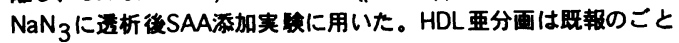
く非变性二次元露気泳勤を用いて分誰し、Western Blottingに て apoA-I, SAAの分布を僄へた。【結果】正常人血繁にSAAを添 加すると、SAAは $\alpha$-HDLと一部LDLに取り込まれ、Pre $\beta$ 1 HDLが6.0 $\rightarrow 13.5 \%$ Alと 125\%增加した $(p<0.05)$ 。超违心で分 讙したHDL 2 とHDL 3 に源加すると、前者ではPre $\beta$ 1-HDLより 柆子サイズの小さいPre $\beta$-HDLか、後者ではPre $\beta$ 1-HDLが出現

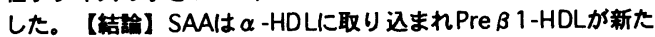
に出現する。SAAによるHDL亜分画の变化か、どのような生理的

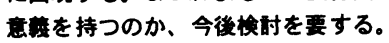

127

コレステロールエステル転換醅素のantisense oligodeoxynucleotide conjugate投与における 血清 $\mathrm{HDL}$ の変化

九州大学生医研気候内科 营野公浩、渡辺美葉、牧野直樹

(目的) コレステロールエステル転換醭素(CETP) は主とし て肝で合成されることより、肝のCETP M R N A 抑制する と、肝および血清のCETPは低下するものと推察される。 今回、我々は、肝特異的レセプターを介して C E T P antisense oligodeoxynucleotide(ODNs) を投与し、肝 のCETP MRNA、血清 CETP活性、血清HDLの変化につい て検討した。(方法) 日本白色家鬼 $(n=24)$ を $0.1 \%$ chol食で約 12 週飼育 $L 、 C E T P a n t i s e n s e$ ODNs (CETPA-ODNs)を耳脆脈より投与した。CETP AODNsはasialoglycoprotein-poly(L)lysine conjugate として投与した。対照としてはCETPsenseODNs(CETP S-ODNs) c onjugateを投与した。CETPODNsを投与後 0 時間、 6 時間、 24 時間、 48 時間、96 時間後に、そ れぞれ 2 羽ずっ家鬼を屠殺し、肝のCETP M R N A d d t blot法にて測定した。また、上記時間に残りすべての家鬼 より、血清CETP活性、血清HDLの変化について测定した。 (結果) C ETPA - ODNs投与後、血清HDLのchol及び\% レステロールエステルは 48 時間で、0 時間及び対照と比 して、有意に上昇した。血清 H DL中のA poA-Iは $24 、 48$ 時間で增加したが、ApoA-Iをもつsmall H DL は 24 時 間で低下していた。肝CETP m R N A 及゙゙血清 C E TP活性は、 $24 、 48$ 時間で、0 時間及び対照と比して、有意に低下 した。対照群では、上記いずれの值とも、どの時間におい ても有意に変化していなかった。（紷括）肝 CETPmRNA は、HDL代謝に重要な役割を持っていることが示唆された。 
128 肥満におけるHDLコレステロール低下とHDL Remodeling

聖マリアン十医科大学 内科学・臨床検査医学教室 $(* 1)$ 、同 難病治療研究センター $(* 2)$ 村上 透 $(* 1 \cdot * 2)$ 、河村英博 $(* 1)$ 、 吉田智彦 $(* 1)$ 、 山崎百合子 $(* 1)$ 、水島 裕 $(* 2)$ 、飯野四郎 $(* 1 \cdot * 2)$

【目的】われわれはこれまで、肥満度増加によりHDLコレステロ 一ル (C) が低下すること、その低下にはコレステリールエステル (CE) 転送の亢進が関与している可能性を報告してきた。今回肥 満患者のHDL remodelingを分析し、その規定因子との関係を検 討した。【方法】未治療肥満患者 $\left(\mathrm{BMI}>26 \mathrm{Kg} / \mathrm{m}^{2}\right) 20$ 例を対象と し、年齢と性をマッチさせた正常体重コントロール $(21<\mathrm{BMI}<$ $\left.23 \mathrm{Kg} / \mathrm{m}^{2}\right) 20$ 例と比較した。リポ蛋白、HDL亜分画および細分画、 Cholesterol Esterification/Transfer Rate (CERおよびCETR) は既報のごとく湘定した。血漿LCATおよびCETP嶩度は抗ペプチ ド抗体を用いた免疫学的方法により測定した。【結果】肥渵患 者ではコントロールに対し、 $\mathrm{HDL}_{2}$-C低下反映によるHDL-C低値と 血漿トリグリセリド (TG)、VLDL-TGの高値を認めた。HDL細分画 では、インキュベーション前の $2 b$ 分画の低值 $(16 \pm 7$ vs $24 \pm 13$ $\%, \mathrm{p}<0.05)$ と $3 \mathrm{c}$ 分画の高値 $(13 \pm 6$ vs $9 \pm 4 \%, \mathrm{p}<0.05)$ を認め た。血墏を $37^{\circ} \mathrm{C}$ で 6 時間インキュベーションした時の変化分 $(\Delta)$ を検討すると、肥満患者では $\Delta 2$ b分画が增加 $(24.9 \pm 12.8 \mathrm{vs}$ $15.1 \pm 8.7 \%, \mathrm{p}<0.02) し \Delta 2$ a分画加低下 $(-5.6 \pm 7.2$ vs $-0.6 \pm$ $4.8 \%, p<0.05)$ した。さらに、HDL particle score $\left(\mathrm{HDL}_{\mathrm{ps}}\right.$ : 値 が大きいほど大粒子HDL増加を意味する)を検討すると、肥満患 者では、 $\triangle \mathrm{HDL}_{\mathrm{ps}}$ が血漿TG $(\mathrm{p}<0.002) 、 \mathrm{VLDL}-\mathrm{TG}(\mathrm{p}<0.002) 、 \mathrm{HDL}_{\mathrm{ps}}$ $(\mathrm{p}<0.05) 、 \operatorname{CER}(\mathrm{p}<0.02) 、 \operatorname{CETR}(\mathrm{p}<0.05)$ とそれぞれ有意な相関 を認めた。一方、血墏CETPおよびLCAT濃度との相関は認められ なかった $(\mathrm{r}=-0.194, \mathrm{r}=-0.137)$ 。【結論】肥満における低HDL-C 血症の成因として、高トリクリリセリド血症とそれによるCERおよ びCETRの方進さらにHDL remodelingが重要であると考えられた。

129 中年男性における性ホルモンと血清HDL-C值の関係につ いて

福岡大学救命救急センター、第二内科・、半田耕一・源宏之・ 拼啓二郎”・武田由紀子”・田中敬一・荒川規矩男・

【目的】テストステロンは血清HDL-C値を低下させるとの報告が ある一方、血中テストステロン渡度とHDL-C值が正の相関を示す ことす知られている。今回我々は血中テストステロン、エスト ラディオールを血清脂質レベルとの関連において検討した。 【対象と方法】313名(50-54踰)の中年男性 (定年前検查)を対象 とした。血清テストステロン、エストラディオール、血清脂質 は醉素法で測定した。肥満度(BMI)、Waist-hip比の測定の他、 喫煙歴、アルコール飲量、physical activityは質問表にて調査 した。

【結果】アルコール飲量、physical activityはtotal及びfree テストステロン值に何ら関係なかったが、血中エストラディオ ールはアルコール常飲者で高值を示した。HDL-C、HDL2-Cはf re eテストステロンと負の相関を示し、エストラディオールと正の 相関を示した(肥満、喫煙、アルコール、physical activityを 補正後)。

【結論】中年男性のテストステロン高值及びエストラディオー ル低值はHDL-C值を低下させ、野脈硬化促進に寄与すると考えら れた。
130 Partial LCAT deficiencyの一家系 大分県立病院第一内科 何松啓志、山口康平 福岡大学第二内科黄 偉、西佳代、松永彰、韓華、 佐々木淳

冠動脈疾患と角膜混濁を伴い、著明な低HDL血症、 partial LCAT deficiencyが認められる一家系を経験した ので報告する。

症例（発端者）：68歳男性 経過：平成7年3月中旬 より胸部圧迫感が出現するようになり3月27日当科入 院。平成7年4月5日冠動脈造影を施行、左冠動脈主幹 部75\%、seg 6-75\%、seg $11-75 \%$ 、seg 4PD-75\%狭窄 を認めた。また両側䅡部に血管雑音を聴取し䅡動脈 造影にて両側䪹動脈および椎骨動脈に狭窄を認めた。 黄色腫や扁桃腫大等は見られないが、両眼の角膜混 濁を認めた。本患者の血清脂質はTC 154mg、HDL-C $2.9 \mathrm{mg} / \mathrm{dl} 、 \mathrm{TG} 198 \mathrm{mg} / \mathrm{dl}$ 、 apo A-I $28 \mathrm{mg} / \mathrm{dl}$ 、Free-chol $65 \mathrm{mg} / \mathrm{dl} 、 \mathrm{CE} 89 \mathrm{mg} / \mathrm{dl} 、$ Free/TC $0.42 、 \mathrm{CE} / \mathrm{TC} 0.58$ であ り、partial LCAT deficiencyと推測された。また患者の 長兄の血清脂質は、TC $140 \mathrm{mg} / \mathrm{dl} 、 \mathrm{HDL}-\mathrm{C} 6.0 \mathrm{mg} / \mathrm{dl}$ 、 Free-chol 48mg/dlであり同一疾患と考えられた。低 HDL血症及びpartial LCAT deficiencyの原因確定のため 現在遺伝子解析を行っている。

Clinical significance of determining urinary mevalonic acid in hyperlipidemia.

Div. of Ather., Metab, and Clin.Nut, Nat Candiovascular Ctr, Res Inst.

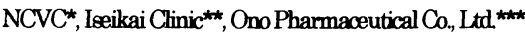
D.Zhao, A.Kanazawa, MSuzuki, KRyomoto, H.Inada*, T.Imai, ** M.Hiramatsu ${ }^{\star \star \star}$, MSugiyama ${ }^{\star \star \star}$ and Y.Harano

(Object) Biochemically, mevalonate(MA) is a key substrate for cholesterol(chol), synthesis Therefore, MA in urine may reflect endogenous chol synthesis.

(Subjects \& Method) Hyperlipidemic subjects including FH, obesity and diabetic subjects were studied for the urinary MA excretion. MA was determined by EIA after purifying urine by using SepPaKPS-1, column . (Results) Inveræe relation was noted between urinary (MA) and æerum T. chol, LDLchol or apoB. While chlofibrate and probucol seemed not to reduce MA, HMGCOA reductaæe inhibitor significantly reduced MA in urine. Noobviouselevation was noted in II a II b and Ihyperlipidemia, nor in diabetes and obesity indicating that degradation rather than synthesis plays a major role in hyperlipidemia. In $5 \mathrm{FH}$ subjects who have been maintained on plasma apheresis, MA increased after apheresis in 4 subjects. In homozygous FH, a relatively higher MA level was noted, suggesting elevation of chol synthesis.

(Conclusion) Negative correlation was noted between serum LDLchol, $\mathrm{apoB}$ and MA exoept homozygous $\mathrm{FH}$, indicating the operation of negative feedback control for chol synthesis. Degradation rather than synthesis plays more important role in hypercholesterolemia. HMGCaA reductase inhibitor significantly lowered MA, indicating suppression of chol synthesis. 

132 LDLレセプター遺伝子異常とコレステロール低下

金沢大学医学部第二内科暒波康二，八木邦公 東方利德, 松下裕之, 藤堂康宏, 川肩㡐照, 野原淳 堀田孝裕, 北谷真子, 稲津明広, 小泉順二, 馬测 宏

[目的] へテロ接合体性家族性高コレステロール血症 (FH)のコレステロール(CHOL)低下療法に対する反応性 とLDLレセブター遗伝子異常との関保の検討 . [方法] FH-Tonami1(Ex.15 del.) 5 例( $(\mathrm{M} / \mathrm{F}=2 / 3$, 平均 54 藏) $2 \mathrm{FH}$ Kanazawa2(P664L) 7 例(M/ $F=2 / 5$, 平均54葴)を対象に, 8週間以上脂質低下剂を休薬した後， pravastatin (P) $20 \mathrm{mg} / \mathrm{D}$ を8週間単独投与。引き続き cholestyramine (C) $12 \mathrm{~g} / \mathrm{D}$ を8週間併用し血清脂質の変化を検討した。[結 果] Tonami1にお引る投与前, P投与時, $\mathrm{P}+\mathrm{C}$ 投与時の TCl $332 \rightarrow 274 \rightarrow 241$ (平均値 $\mathrm{mg} / \mathrm{dl}$ ), LDL-Cは $270 \rightarrow$ $204 \rightarrow 164$, HDL-Cは $38 \rightarrow 44 \rightarrow 50$ とそれそれ有意( $p<$ 0.05)に低下ならびに上㫒した。同様にKanazawa2にお ける平均TCは $354 \rightarrow 269 \rightarrow 207$, LDL-Cは $300 \rightarrow 211 \rightarrow$ 142 , HDL-Cは $33 \rightarrow 40 \rightarrow 45$ とそれぞれ有意 $(p<0.05) に$ 変化した。両群とも TG，Lp(a)に有意な変化はなかった。 Tonami1およびKanazawa2 2におけるLDL-Cの低下量(平均 值 $\mathrm{mg} / \mathrm{dll)}$ は，P投与で66および90(p>0.2), Cの追加投 与で40および69(p<0.01)，P+C併用で 107および159 ( $<<0.01)$ であり, 低下率(\%)の比较においても同様の有 意差を認めた. HDL-Cの変化量, 変化率には有意差を 認めなかった。以上の結果から Kanazawa2はTonami1に くらべCHOL低下㙩法により反応すると考えられた。 [結語］FHにおけるCHOL低下寮法に対する反応性は, LDLレセブター㟟伝子異常によって规定されている．

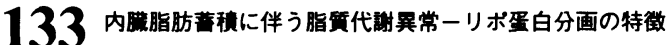
とLDL particle size 大阪大学医学部第二内科 小林一史 山下静也 船㛢微 中村 正 木原進士 石神员人 竹村 芳 松沢佑次 大塚アッセイ研究所 白杵嘖晃 福田陆司

【目的】われわれはこれまで、肥満の有無に関わらず内䑏脂肪蓄 稓を基盤とし multiple risk factorの集筷する病態を内䑏脂肪症 候群として提唱してきた。今回は内䑏脂肪蓄樻による脂筫代的買 常についてリポ蛋白分画およびLDL particle sizeを模討したの で、その特徵について報告する。

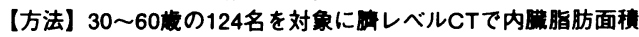

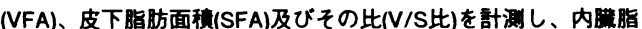
肪型肥渶群(NFO)、皮下脂肪型肥渶群(SFO)、非肥渶内灌脂肪蓄

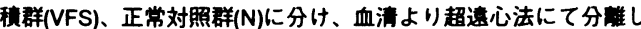
たリポ蛋白分画のコレステロール(Ch)、トリグリセリド(TG)、ア ポBを测定して比較检讨した。また、同時にLipophorシステム用 いてLDL particle sizeを計测し、各因子との関連を睐価した。 【結果】VLDL,IDL,LDL分画ではCh,TGともにVFO,VFS >N, SFOであった。LDL-apoB、LDL-TG/Ch比も同様であり LDL-Ch/LDL-apoB比はSFO,N >VFO,VFSであった。HDL2分 画ではChはSFO,N>VFO,VFSでTGには差を認めなかった。 LDL particle sizeはVFO,VFSにおいて有意に小さく、非肥满者 においてはVFAと、肥渾者においてはV/S比と有意な角の相関を 示した。

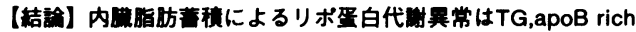
リボ蛋白の滥加と、small dense LDLを特儌とすると考えられ

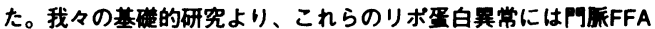
の上年に起因したミクロゾーマルトリグリセリド転送蛋白(MTP) の活性上昇の関与が示业される。
134 コレステロール摄取による血清リポ蛋白亜分画の変化と L D L-レセプター活性

東海大学大磯病院 内科

○本間康彦, 小林俊雄, 小讯秀樹, 山口 浩, 坂根浩弥, 三神美和

【目的】コレステロール (C) 経口負荷時の血清リポ蛋白要分画の 変化と LDL-レセブター活性の関係を検討した。

【方法】30例の対象にC $750 \mathrm{mg} /$ 日、 2 週間摄取させ、前後で血清 リボ蛋白㩊分画一C 值を測定した。血清りポ蛋白は、VLDL, IDL, $\mathrm{LDL}_{1}, \mathrm{LDL}_{2}, \mathrm{HDL}_{2}$, $\mathrm{HDL}_{3}$ K超遠心法により分画した。末梢血りン 八球LDLーレセブター活性をflow cytometryにより測定した。 【結果】C負荷前の血清りポ蛋白重分画-C 值とLDL-レセプター活 性は、LDL $1-C$ 值とのみ有意の相関 (逆相関, $\mathrm{r}=-0.467, \mathrm{p}\langle 0.02$ ) が認められた。C負荷により、血清りポ蛋白要分画一C值は、全 体として有意の変化は認められなかった。LDLーレセブター活性 とコレステロール負荷によるVLDL-C, IDL-C, LDL 1 -C, LDL 2 -C変化 との間には有意の相関は認められなかった。LDLーレセプター活 性と $\mathrm{HDL}_{2}-\mathrm{C}(\mathrm{r}=-0.581, \mathrm{p}<0.001)$, お。ひびHDL3-C $(\mathrm{r}=-0.506$, $\mathrm{p}\langle 0.01)$ との間に有意の逆相関が喼められた。 【結論】LDLーレセブター活性が低い人日ど、コレステロール摄 取でHDL $2-\mathrm{C}, \mathrm{HDL}_{3}-\mathrm{C}$ 值は上昇するか、 $\mathrm{LDL}_{1}-\mathrm{C}, \mathrm{LDL}_{2}-\mathrm{C}$ 值の変化は LDLーレセブター活性とは直接的な関係はないと考えられた。

135 M-CSF及びLDL受容体欠椇マウスにおける贸状助脈硬化 東京大学医学部第三内科

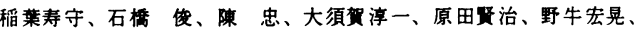
大榙揵、山田信博、矢崎義雄

く目的〉大理石病のモデル動物であるop/opマウスは、M-CSF 速 伝子異常に起因し、単球・マクロファージ系細胞がほとんと存在 しない。このマウスは助脤硬化症進展通程における単球・マクロ ファージの役割を知る上で非营に有用なモデルである。そこで、 M-CSF及U゙LDL受容体欠椇マウス(op/opxLDLR-/-)妾作慗し、高

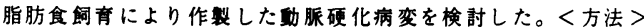
op/+マウスとLDL受容体欠損マウス(LDLR-/) を交配し、 op/opxLDLR-/.を作慗した。コントロールマウスとして同腹の LDLRー/を使用した。血策中リポ蛋白ブロファイルはHPLCを用 いて測定した。血整中脂兵の测定は醇莱法で測定した。高脂肪 食鲇育 10 週後、マウスを屡耓し、摘出した大助脈内峔をSudanIV 染色した。く耛果 > OP/OP*LDLR-/てで、普通食铜育下での空 腹時 $\mathrm{TC}$ は有意に增加していた。これは 分の增加による。さらに、高脂肪食同育 10 週後では空腹時TC 及 びTG值がそれぞれ1.7、1.8倍に增加していた。特に、apoB含有 巨大粒子( $\beta$-VLDL)が顥著に增加していた。また、LDLR-/では

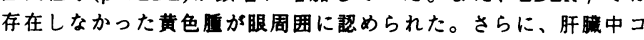
レステロール含貫が約9.4倍であった。しかし、大動脈における 病変面は、OP/OP*LDLR-1-及びLDLR-/ーでれぞれ<5、30\% であった。く結論〉OP/OP*LDLRー/は、LDLR-/にに比して普通 食及び高脂肪食緟育下においてもTCがより高值を示したが、そ れにもかかわらず動脈硬化は㧕制されていた。以上のことから、 助脈硬化症発症には単球ーマクロフォージの関与が非莹に重要て あると考えられた。 


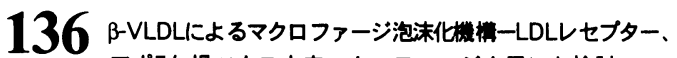
ア枤次提マウス由来マクロファージを用いた模时一 東京大学第三内科

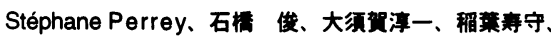

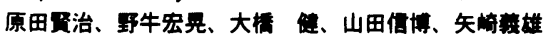

[目的]B-VLDLによるマクロファージの泡沫化には細胞表面

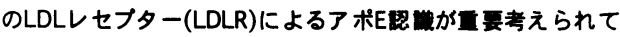
きた。近年、LDLR道伝子ファミリーに属するレセプター蛋白 であるLRPやVLDLRレセブターが相次いで報告され、これら のマクロファージの泡沫化への䦛与が想定されている。そこ

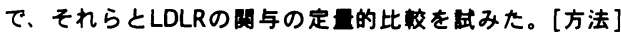

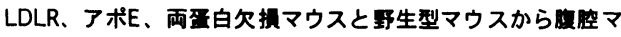
クロファージ(MPM)を眐監した。LDLR欠提マウスおよひアポ E欠損マウスを高コレステロール食で铜育し、刧违心法により $\mathrm{d}<1.006 \mathrm{~g} / \mathrm{ml}$ 分画を国基し、それそれ、アポE(+)ß-VLDL、 アホホE(-)B-VLDLとした。LPDS前処理後のそれそれのMPMと リポタンパクとをインキュベートし、新たに $\left[{ }^{14} \mathrm{C}\right]$ オレイン酸

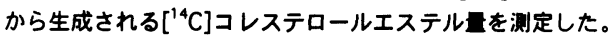

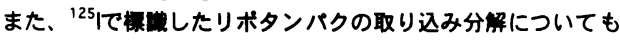

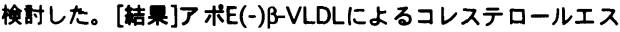

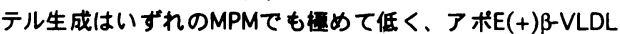
は野生型とア术E欠损マウス由来MPMのコレステロールエス

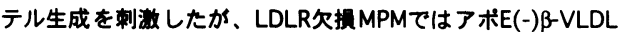

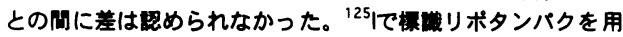

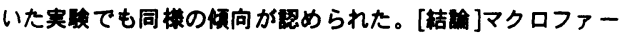

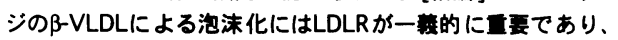
LRPやVLDLRの䦥与は無䄈しうると考えられた。

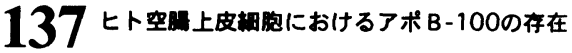

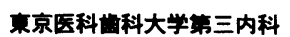

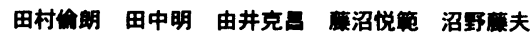

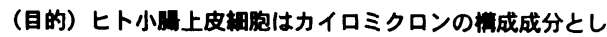
てアポB-48を合成分泌することは如られているか，アポB -100の合成分泌については搉琵されていない，近年我々は アポB-48を现詪しない抗アポB-100マウスモノクローナ

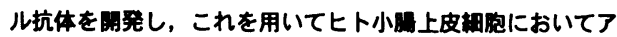
ポB-100が存在しているか否かを畔へた。

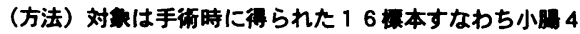

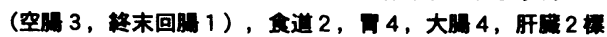
本で, 上㲹抗体を用いStreptavidin-biotin (SAB) 法にて 免落租權染色を施行した.

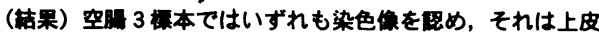

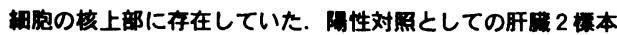

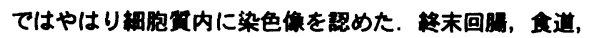

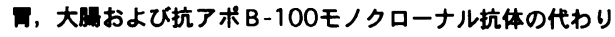

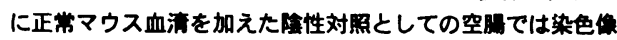
は既められなかった.

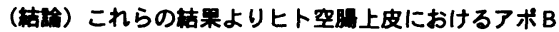

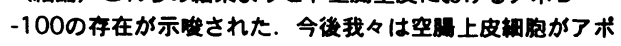
B-100を産生しているか否かを碓琵し，アポB-100の空 閦上皮における役揢を湌时する予定である.
138 TG処理能(K2値)とリポ蛋白リパーゼの対比

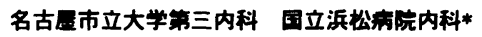

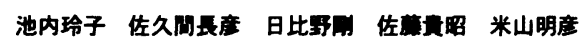

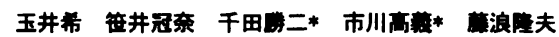

（目的）われわれはTGrichリ木蛋白の異化這度をあらわす指标

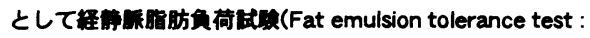
FETT)を行い、 fat emulsionのfractional catabolic rate(K2值)を

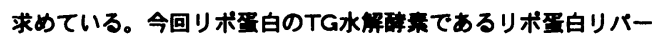

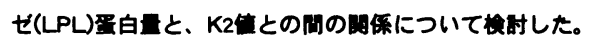

（方法）正留血者ならびに高TG血者17名(男性12名、女性5名、

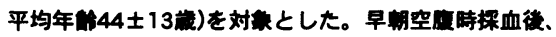
10\%intralipid0.25m1/kg体亘を解注してFETTを行った。FETT

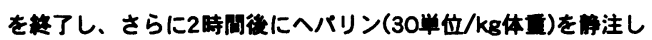

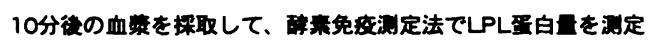
した。

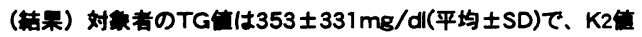

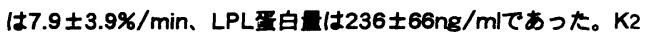

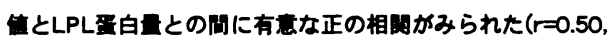
p<0.05)。

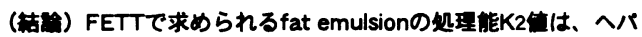

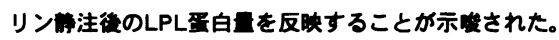
ApoE deficient mouse の生体内コレステロール代謝

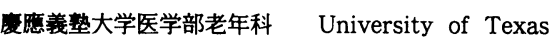
小團 康籍 Laura A. Woollett, John M. Dietschy

目的：ApoEのノックアウトがマウスの生体内コレステロール (CH) 代即にどのように影暗するのかを検討する。

方法 : 生後 3-4 ケ月の ApoE deficient mouse(ApoE- KO) と control(C57BL/6)において in vivo LDL コレステロール(LDL-C) クランプ法でLDLクリアランスを, DPS 法で in vivo $\mathrm{CH}$ 合成量を, 各搭器と生体全体で測定した。CH吸収率は鿓便回収法で測定し

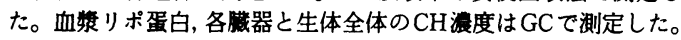
結果 : 肝滕のLDLクリアランスはApoE-KOで $560 \pm 86 \mu 1 / \mathrm{h} /$

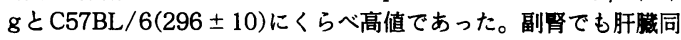
様に著明にクリアランスが六進していた。ApoE-KOでは血嶈 CM /VLDL-C 漼度がC57BL/ 6 の $5 \pm 0 \mathrm{mg} / \mathrm{dl}$ から $325 \pm 38 \mathrm{mg} / \mathrm{dl}$

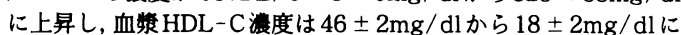
低下していた。肝践のCH合成はApoEのノックアウトによっても C57BL $/ 6$ の $1641 \pm 137 \mathrm{nmol} / \mathrm{h} / \mathrm{g}$ から $1457 \pm 164$ と有意な変 化はなく, 副骨では $750 \pm 114 \mathrm{nmol} / \mathrm{h} / \mathrm{g}$ から $402 \pm 38$ と低下し ていた。また,精巣では $117 \pm 7 \mathrm{nmol} / \mathrm{h} / \mathrm{g}$ から $285 \pm 11$ に合成

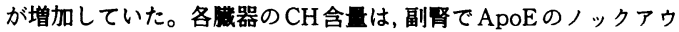
トによって $26 \pm 4 \mathrm{mg} / \mathrm{g}$ から $7 \pm 1 \mathrm{mg} / \mathrm{g}$ まで低下した。 $\mathrm{CH}$ 吸収 率に有意差はなかった。

考察 : マウスの ApoEをノックアウトすると, 血漿 CM/VLDL-C

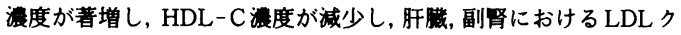
リアランスが増加した。ApoEはCM/VLDL浱度決定に大きく関 与し, LDLリセプターのLDL取り込みに関してApoB と競合してい ることが in vivoでも裏付けられた。また, 副堅, 精巣のコレステ ロール代即にも ApoEが稓極的に関与していることが示唆された。 
140 ア术蛋白E2、E4代静の检时一ヒトアポ蛋白E4/2ヘテロ 接合体でのin vivo 代期実伢からの知見

東京慈恵会医科大学青戸病院内科、 NIH：池䏦克則、多田紀夫、

望月正武、D. J. Rader、H. B. Brewer, Jr.

【目的】アポ蛋白Eには通伝的多䓇性があり、E2,E3,E4の 3 種類 のイソ蛋白が存在する。その中でもE2とE4は、LDL受容体との親和 性、リ术蛋白間分布、LDL-コレステロール (C) 値やLDL受容体活 性への影䈉が大き異なることが知られている。今回我々は、E4/2 ヘテロ接合体患者で、LDL受容体活性が同じ状態でのこれらアポEイ ソ蛋白の代期を検討した。

【対象、方法】 $E 4 / 2$ ヘテ口接合体3名（正脂血症 2 名、柽度高脂血 症1名）に ${ }^{131} \mid$-apoE2、125l-apoE4を同時に䍵注した。全血墏およ び各リポ蛋白を超遠心法にて分画し、それそれの radioactivityを fraction of injected doseとしてプロットした。アポ蛋白の residence time (RT)は、血墏消失曲線をthree-pool modelに当 はめ、SAAM31を使って簐出した。

【結果】ラベルしたアポ蛋白Eは、apoE2が主にHDLに分布したのに 対して、apoE4はVLDLとHDLに均等に分布する傾向が照められた。 apoE2 とapoE4のRTは、それそれ $1.20 \pm 0.18$ daysと0.40 0.01 daysであった。全てのリポ蛋白分画でapoE4はapoE2より速く代期 された。

【結語】apoE4の異化速度はapoE2の3 倍にえ進していた。apoE4の 異化の亢進は、リポ蛋白間の分布の䢖いだけでなく、アポ蛋白Eを有 するそれそれのリボ蛋白での異化の亢進によることが考えられた。 これらの所見から、apoE2とapoE4は同一個体においても独立した 代㽎形式を持つことが示唆された。
141 リポ蛋白リパーゼを過剩発現したアポEノックアウト マウスの血獎りポ蛋白代謝の検討 東京大学医学部第三内科 1 、東京医科歯科大学教養部 ${ }^{2}$ 野牛宏晃 1 、石橋 俊'、嶋田昌子!、岡崎三代 ${ }^{2}$ 、陳 忠! 大須賀

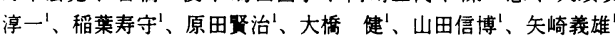

[目的] LPLはレムナントリポ蛋白の産生及び取り込みに重要な 酵素である。最近、我々は、LDL受容体欠損マウスにLPLを過剩 発現させることにより、コレステロールの低下を認めると共に動 脈硬化の進展を抑制できることを報告した。そこで、LPLのコレ ステロール (TC) 低下作用におけるアポEの役割を明らかにする ため、LPLトランスジェニクマウス (LPLTg+/-) とアポEノックア ウトマウス (APOEKO-/-)の交配を行い、その血槳りポ蛋白代謝 について検討した。[方法] 1) chicken $\beta$-actin promotorによって human LPLを過剩発現させた (LPLTg+/-) マウスと (APOEKO-/-) マ ウスの交配により (LPLTg+/-;APOEKO-/) マウスと (APOEKO-/-) マウスを作蹩した。 2 2) 16時間絶食後のplasmaについて、血墏脂 質、リポ蛋白、アポ蛋白の解析を行った。[結果] (LPLTg+/-; APOEKO-/) 群は (APOE-/) 群と比較して、トリグリセライド (TG)の有意な低下を認めた $(25 \pm 9 \mathrm{mg} / \mathrm{dl}, \mathrm{n}=14$ vs. $104 \pm 46$ $\mathrm{mg} / \mathrm{dl}, \mathrm{n}=21 ; \mathrm{p}<0.01)$ 。TCの有意差は認めなかった $(499 \pm 223$ $\mathrm{mg} / \mathrm{dl}$, vs. $656 \pm 248 \mathrm{mg} / \mathrm{dl})$ 。HPLC法によるリポ蛋白分画の解析 では、(APOE-/) 群に比べ (LPLTg+/-;APOEKO-/-) 群において non-HDL分画の粒子サイズの小型化、HDL分画の增加、TG含有 量の低下を示した。SDS-PAGEにおいて、(LPLTg+/-;APOEKO-/-) 群のIDL, LDL分画のアポB48の增加を認めた。[結論] 既に報告 したLPL過剩発現によるLDL受容体欠損マウスの結果と共に考え ると、LPLは、アポEの存在下においてTC低下作用を発揮するも のと推測された。
142 APOBEC-1 ノックアウトマウスの樹立と解析 ーアポB48欠失のリポタンパク代唄への影䨘一 東京大学第三内科

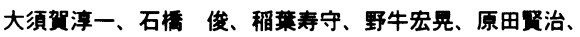
大檑 健、山田偣博、矢崎䣡雄

[目的]アポB48はアポBCDNAの第6666塩基のCをUへ置換する アポBmRNAeditingによって生成される。この醉柤反忘は近年 TengらによりクローニングされたAPOBEC-1とその他の㭪因子 からなるeditosomeにおいて行われる。アポB48の生理的意䣡 を明らかにするために、ES細胞を用いた相同的組換えにより APOBEC-1ノックアウトマウスを作製した。[方法]APOBEC-1の 活性中心と考えられるエクソン6のZn結合領域にネオマイシン 耐性遗伝子とポリAを扱入したベクターをES細胞にトランスフェ クトし、相同的組換え体を得た。変翼ES細胞を胚盤胞にマイク ロインジェクションしキメラを得た。ヘテロ同士の交配により ホモ接合体マウスを得た。APOBEC-1はノーザンブロットとイ ムノブロットを用いて模出し、アポBmRNAediting活性は primer-extension法により测定した。[結果]独立した2系統の子 孫に変暴を伝えるキメラが得られた。ホモ型変翼マウスは APOBEC-1タンパクを完全に欠失したnull型であった。表現形は

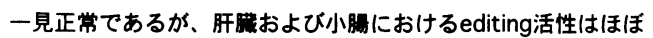
完全に欠失し、血獎中のアポB48も模出されなかった。血墏TC、 HDL-C及びTC位は木モ型変哄と野生型の問で有意差は揌められ なかった。[結諭]APOBEC-1ノックアゥトマウスを樹立した。血

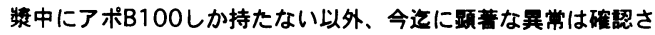

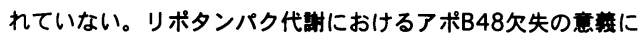
ついての群細は現在模讨中である。

リポ蛋白リパーゼの基質としての chylomicron 粒子異常が 原因と思われた $\mathrm{V}$ 型高脂血症

千葉大学医学部第二内科

正田 稳 小林淳二 武城英明 清宮晃一 森崎信尋 齊藤 康

【目的】下垂体腫塲摘出症例にみられた $\mathrm{V}$ 型高脂血症の成因を明 らかにする。【症例】32才女性。身長 $153 \mathrm{~cm}$, 体重 $49 \mathrm{~kg}$ 。7才時、 下垂体腫夠の摘出術を受けた。5年前より高脂血症を指摘されてい る。入院時血清総コレステロール (TC) $217 \mathrm{mg} / \mathrm{dl}$, 中性脂肪 (TG) 799 mg/dl, HDL-C 24 mg/dl, apo-AI 107, AII 48, B 93, CII 9.4, CII $17.2, \mathrm{E} 15.2 \mathrm{mg} / \mathrm{dl}$ と高中性脂肪血症と低 HDL 血症を認めた。ま た、血清 GH, LH, FSH, cortisol の著明な低下が認められた。 【方法】リポ蛋白リパーゼ ( LPL) 活性はTriton X-100にて釈化し た基質を用いて測定した。LPL 酵素蛋白量は ELISA 法にて测定し た。 chylomicronは健常人にバターを $40 \mathrm{~g}$ 経口負荷し、2時間後に 採血して得られた血清より調整した。健常者と患者 chylomicron への tri[ $\left[1{ }^{14} \mathrm{C}\right]$ oleoyl glycerol によるラベリングは dimethylsulfoxide 法を用いた。脂肪負荷試験は早朝空腹時 $40 \mathrm{~g} / \mathrm{m}^{2}$ の生クリ 一ムと $50000 \mathrm{IU} / \mathrm{m}^{2}$ の vitamin $\mathrm{A}$ を経口投与し、 $0,2,4,6$ 時間後探 血して血清中の retinyl palmitate 洪度を測定した。【結果】へバリ ン $(30 \mathrm{U} / \mathrm{kg})$ 静注 15 分後、血清 TG の低下を認めなかった。このと き血清 LPL 活性、蛋白量と肝性リバーゼ (HL) 活性はいずれも正 常値を示した。in vitroの検討で患者 chylomicron は健常者 chylomicron と比較し LPL による水解が約1/6に低下していた。脂 肪と vitamin A 負荷後の retinyl palmitate 代謝は患者で正脂血者 $(n=5)$ と比較し著しく遅延していた。

【結論】患者の高脂血症の成因として水解反応からみて chylomicron 代謝が障害されていることが判明しその原因として LPL や HL の低下ではなく chylomicron 粒子の異常によるクリアラ ンスの低下の可能性が示唆された。 
144 lipoprotein glomerulopathy小児例における血嶈脂質分析と そのTG-rich リポ蛋白のヒトマクロファージに対するコレス テロールエステル合成能の検討

日鋼記念病院内科*、旭川医科大学第 2 内科炏、東京都国保連福生 病院小坚科*** 斎藤美恵子*、衛藤雅昭**、松山健***

〔目的〕lipoprotein glomerulopathyはまれな疾患で、現在まで小 児例 4 例を含む 20 数例が報告されている。われわれは而型高脂血 症を発症し、 lipoprotein glomerulopathyの病態を呈した 10 才男 児例を経験した。その堅病変と脂質の関連の詳細は不明であるが、 マクロファージの関与も示唆されており、今回、本患者のトリグリ セライド(TG)-rich リ沝白のヒトマクロファージに対するコレス テロールエステル合成能も検討した。[方法]本患児より早朝空腹 時に採血し、超遠心法および電気泳動法よりリポ蛋白分析した。ア ポ $\mathrm{E}$ 表現型は等電点電気泳動法により行った。患児TG-rich リポ蛋 白 $(\mathrm{d}<1.019)$ を培養液中 $100 \mu \mathrm{g} / \mathrm{ml}$ コレステロール濃度に調整し、 ヒ卜単球由来マクロファージとインキュベーションし、マクロファ ージに対する14Cオレイン酸のコレステロールエステルへの取り込 み能を検討した。堅生検し、組織像も検討した。【結果〕患児の血 中総コレステロールおよびTG值はそれぞれ $295,415 \mathrm{mg} / \mathrm{dl}$ 之高值を

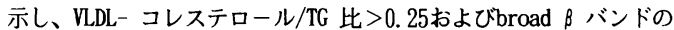
存在により孟型高脂血症と診断された。RLP コレステロールは 39.6 $\mathrm{mg} / \mathrm{dl}$ と高値であった。アポ $\mathrm{E} 3 / 2$ 表見型であった。光影では糸球 体は腫大し、㹡張した毛細管くう内に脂肪染色晹性塞栓样物質の充 満が見られ、電影では嚢状構造物を認め、lipoprotein glomerulopathyの組織像に一致した。患児TG-rich リポ蛋白のヒト単球由来 クロファージに対するコレステロールエステル合成能は0.598 nmole/mg cell protein であり、同年令対照児の 0.187 に比へて有 意に $(\mathrm{p}<0.001)$ 高値であった。〔結論〕本男児例はアポ $\mathrm{E} 2$ 、血型 高脂血症を有し、そのレムナントを含むTG-rich リポ蛋白はマクロ ファージに対するコレステロールエステル合成能が高值であった。

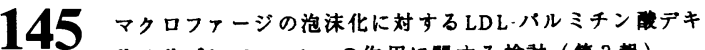

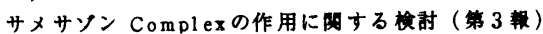

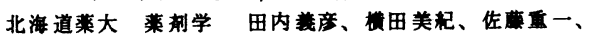
伊藤圭二

【目的】我々はLDLを担体として、弱状野展硕化初期病菓人莱物

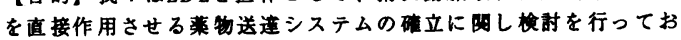
ク、昨年度本学会冬季大会にて、LDLにバルミチン敐ア゙キサメサ ソン(D-pal)を取り迟ませたComplexを化处理した化

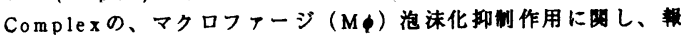
告した。今回、第処理のComplexによるMめ泡沫化に对する卯 制作用について榆村したのて、、その桔果を赫告する。

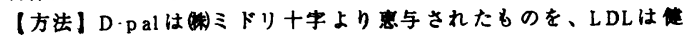
常人血策より超息心法で分倍したものを用いた。 Complexは、 セライト545存在下、LDLとD-palを 37 Cで掁とう培荟した後、

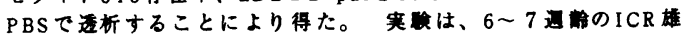

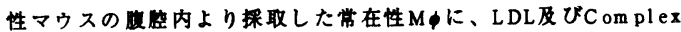

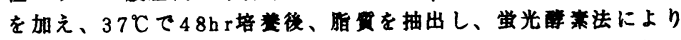

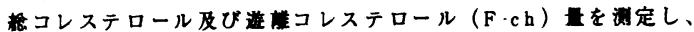
その差よりコレステロールエステル（CE）具を算出した。

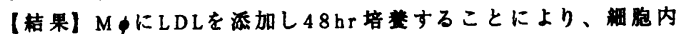

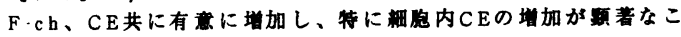

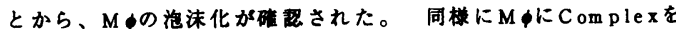

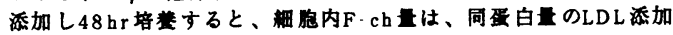

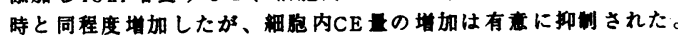
さらにComplexをLDLと同時、または LDL深加 $24 \mathrm{hr}$ 後にM ゆに

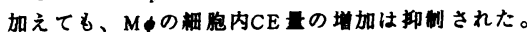

(結鉿) Comlexは、LDLと同模にMфに取り达まれた啳、D·pal

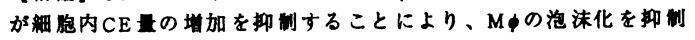
することが示睃された。
146 Brefeldin A (BFA) 耐性マクロファージにおけるACAT (acylcoenzyme A:cholesterol acyltransferase) 活性の減少

熊本大学医学部第二生化学

丁 怡、枳田秀樹、松田浩史、枇杷 剛、川野尚、坂本裕一郎、 川崎隆史、蓮沼咗子、堀内正公

【目的】 Brefeldin A (BFA) はTGN (トランスコルルジットワーク)の 阻害剂として知られ、細胞内コレステロール代謝系への関与が示唆 されているが、分子レベルの情報は非常に少ない。今回我々は、 BFAの標的分子とマクロファージ $(M \phi)$ のコレステロール代謝系と の相互作用を分子レベルで解析するための第一歩として、BFA奧性 $\mathrm{M} \phi$ 変異株を分離し、特にACATに注目して解析した。【方法】マ ウスM $\phi$ 細胞株J774を突然変異剂で処理した後、BFA $(1 \mu \mathrm{g} / \mathrm{ml})$ に対 して耐性を示す变異株を分離し、アセチルLDLによる泡沫化の程度 を放射標識オレイン酸の取り込み、並びに醭素営光法による細胞コ レステロール総量の定量によって検討した。ACATについては、 microsomal ACAT活性、再構成ACAT活性、並びにタンバク質発現を ウエスタンブロッティングによって検討し、それぞれ親株J774と比 較した。【結果】BFAに対して3株が耐性株として分離された。そ の中の一株であるJB23について解析したところ、アセチルLDLによ る泡沫化の程度は50\%に減少していた。いくつかの可能性の中、 ACATの活性低下に注目したところ、microsamal ACAT活性はほとん ど変化がないが、再構成ACAT活性はJ774の60\%に減少していた。ウ エスタンブロッティングの結果から、再構成ACAT活性の変化に対 応して、ACATタンバク質発現が滅少していることが判明した。【結 論】 BFA耐性に関わる分子は、M $\phi$ の泡沫化にも関与する可能性が ある。現在、ACAT mRNA発現、スカベンジャー受容体活性並びに ゴルジ機能について検討中である。

川鉄千葉病院内科、“千葉大学第二内科

佐々木憘裕、新原久美子、周藤原*

[目的] scavenger receptor(SCR)のみならず LDL receptor(LDL-R)を 有しているJ774macrophage $(M \phi) に$ acetyl LDL (acLDL)およびLDL を負荷し、細胞内の脂筫組成の変化と、cholesteryl ester (CE)合成酵 素の acyl CoA:cholesterol acyltransferase (ACAT) phosphatidylcholine (PC) $の$ de novo $の$ 合成酵素 cholinephosphotransferase (CPT)活性の変化を検討し、SCR およひ LDL-R 経路の代謝上の速いを明らかにする。LDL および Basu らの 方法で作成した acetyl LDL(acLDL)を 0-200 $\mu \mathrm{g}$ cholesterol $/ \mathrm{ml}$ の浱度 で培基 J774 M $\phi$ に負荷し、24 時間後に、細胞の homogenate より postnuclear fraction を調整し、脂貿組成を、酳素法および flame ionization detector 法にて分析し、ACATおよびCPT 活性を測定した。 [結果] acLDLの負荷にて細胞内の CE は acLDLの量に応じた著明 な增加 $(94.5 \mu \mathrm{g} / \mathrm{mg}$ protein)を示した。free cholesterol(FC) は $75.6 \mu \mathrm{g} / \mathrm{mg}$ protein(33.2\%)增加した。醭素法で測定したリン脂質(PL) は $54.8 \%$ 增加した。FID 法による解析では PL 中 phosphatidylethanolamine と sphingomyelin の変化はなく、PCの增 加を示していた。またACAT およひ CPT 活性はそれぞれ 137\%。 $56.8 \%$ 上昇した。一方 LDL の負荷では FC は $84.6 \mu \mathrm{g} / \mathrm{mg}$ protein(37.1\%)の增加を示したが、CEは $3 \mu \mathrm{g} / \mathrm{mg}$ protein の增加を認 めるのみであった。PLは 37.8\%增加した。ACATおよび CPT 活性 はそれぞれ $118 \%, 83 \%$ 上梨していた。[結論] J774(M $\phi)$ では acLDL はCE 菨穔させるが、LDLはFC、PLの增加をさせ、ACAT 活性も上 昇していたがCEの蓄糟は起こらなかった。ACAT活性の上昇には細 胞内の FCの增加が役割を果たしているが、LDL-R 経路由来の FCは ACATに基筫として available な状態にならず、ScR 経路由来の FC とは異なる代謝経路をたどると考えられた。また LDL およひ acLDL による細胞内に增加するPCはCPT 活性の上昇による de novo の合 成穴進に基つくことが推測された。これらの cholesterol の代即経路 の差異やCPT 活性の上昇の意緟について明らかにする必要がある。 
148 ヒト大動脈壁における酸化LDL受容体CD36及びスカベン ジャー受容体の発現差異について一免疫組樴学的検討一 大阪大学第二内科 中田鞂之、野崎秀、宮川洞一郎、西田 誠 田村 律、中川理、山下静也、竹村 芳、松沢佑次

【目的】CD36はトロンボスボンジン、コラーゲンおよび酸化 LDL受容体であることが知られている。我々は昨年CD36のヒト 大動脈組樴での発現を報告したが、今回従来より知られている酸 化LDL受容体のスカベンジャー受容体 (ScR. type1, 2) の発現もあ わせて検討した。【方法】剖検にて得た大動脈より凍結標本を 作製。一次抗体としてFA6-152 (anti-CD36 antibody) およびSRI-2 (anti-ScR type1 and 2 antibody) を用い、LSAB法により免疫染色を 施行。また、HAM56 (anti-macrophage antibody) を用いマクロファー ジ $(M \phi) を A B C$ 法により染色、脂肪染色としてOil-Red O染色を施 行した。【結果】1) 正常の大動脈内膜に存在するMфには、CD36 の発現は認められなかったが、ScRは陽性であった。2) 動脈硬 化巣では、内膜直下に存在するMфにはCD36の発現は殆ど認めら れないが、ScR活性は陽性であった。それに対し、硬化巣の深部 の大型の泡沫化したMфではCD36の発現が強く認められ、逆に ScR免疫活性は低かった。Oil-Red O染色で陽性の部位とCD36陽 性の部位はほほ一致していた。【総括】動脈硬化巣形成過程で CD36とScR (type 1, 2) の役割が異なる可能性が示唆された。
149 マクロファージスカベンジャーレセプター機能に及ほす インスリン作用についての検討

熊本大学医学部第二生化学

佐野裕之、東 隆行、陣内良映、堀内正公

【目的】インスリン治療によって、組織に沈着したAdvanced Glycation End products (AGEs)が減少することが報告されている。生体 内におけるAGEs除去機能解析の為に、インスリン作用とAGEレセブ ターとしてのマクロファージスカベンジャーレセブター(MSR)の関 係について検討した。【方法】(1)CHO細胞を用いて、MSRとイン スリンレセプター(IR)を過㮃発現したCHO-SRII-IR細胞を榯立した。 この細胞を用いてインスリン刺激によるAGE-BSAの取り込み・分解 について検討した。(2)更にIR kinase deficientのIR ${ }^{1030 \mathrm{M}}$ とIRS-1 or -2 と の結合能を欠く $<\mathrm{IR}^{972 \mathrm{~F}}$ 用いCHO-SRII-IR ${ }^{1030 \mathrm{M}}$ 細胞とCHO-SRII-IR ${ }^{972 F}$ 細胞を作成し同様の実験を行った。(3)CHO-SRII-IR細胞を用い(1)の 系における wortmannin, LY294002, rapamycinの効果を检討した。 (4)RAW細胞にIRを過剩発現したRAW-IR緗胞を作成し(1)(3)と同様の 检討を行った。【結果】(1)(2)CHO-SRII-IR細胞におけるAGE-BSAの 取り込み・分解はインスリン浱度依存性に增加を示したが、CHOSRII-IR ${ }^{1030 M}$ 細胞とCHO-SRII-IR ${ }^{972 F}$ 細胞はインスリン反応性を示さな かった。(3)wortmanninとLY294002はインスリン刺激によるAGE-BSA の取り込み・分解を抑制したが、 rapamycinは影慗しなかった。(4)マ クロファージ系細胞であるRAW-IR細胞においても、インスリン刺激 によるAGE-BSAの取り込み・分解の增加を示し、この反応は wortmanninによって抑制された。【結論】我々の系において、イン スリンはMSRを介したAGE-BSAの取り込み・分解を元進した。その 際、PI3 kinaseを介した経路の重要性が示唆された。
150 酸化LDしによるマクロファージ增殖におけるGM-CSFの関与 熊本大学医学部第二生化学 代㴬内科学

枇杷 剛、桍田秀樹、松田浩史、川野 尚、坂本裕一郎、丁 怡、 川崎隆史、蓮沼裙子、竹村 亨*、松村 剛"、堺 政和" 小堀祥三*、七里元完*、堀内正公、

【目的】我々は in vitroにおいて酸化LDLによってマウス、ラット およびヒトマクロファージ $(M \phi)$ が增殖することを報告している。 今回、酸化LDLによるマウスM $\phi$ の增殖におけるサイトカインの関 与について検討した。【方法】細胞は雄ddyマウス腹肱M $\phi$ を用い、 細胞数測定、及び放射性チミジンの取り込みを増殖の指標とした。

(1) M $\phi$ を酸化LDLと保温して增殖させる実験系で、培荺液の交 換の影響を検討した。(2)酸化LDLによるM $\phi$ 增殖に対する 4 種の サイトカイン中和抗体 (ヤギ抗マウスGM-CSF抗体，ヤギ抗ヒトMCSF抗体, ヤギ抗マウスIL-3抗体,ヤギ抗マウスIL-5抗体) の効果を検 討した。 (3) M $\phi$ に酸化LDLを添加した後、経時的に培费上清中 のGM-CSFの浱度を測定した。(4) 上記 4 種のサイトカインのM $\phi$ 増 殖に対する影響を検討した。【結果】(1) 培地交換なしでM $\phi$ を酸 化LDLと6日間保温したときの放射性チミジン取り込みを100\%とす ると、24時間ごとの培地交換の回数に依存してチミジン取り込みの 抑制が認められた (1度交換: $50 \% 、 2$ 度、3度交換:それぞれ $82 \%) 。(2)$ 液性因子の関与が示唆されたため、上記サイトカイン中和抗体を酸 化LDLと同時添加すると、GM-CSF中和抗体は酸化LDLによるM $\phi$ 增殖を細胞数測定で $90 \%$ 、放射性チミジンの取り込みで $80 \%$ 抑 制した。これに対しM-CSF, IL-3， IL-5の中和抗体は有意な抑制作用 を示さなかった。(3) 酸化LDLによって、M申培畨上清中のGM-CSF は酸化LDLの浱度依存的に上畀し、4 時間でビークを認めた。(4) 培萑中に上記サイトカインを単独添加すると、GM-CSF $>$ M-CSF $>$ II-3の順に有意にM $\phi$ 増殖を誘導したが、正-5に誘道効果は認め られなかった。なお、酸化LDLによって誘導されるGM-CSF瀑度は、 M申の增殖を誘導する浱度に匹敵した。【結論】酸化LDLによるマ ウスM申增殖において、GM-CSFの関与が示唆された。

151 酸化LDLによるマクロファージ増殖におけるGMCSF産生に対するPKCの関与

熊本大学代謝内科学. 第 2 生化学*

松村 剛、堺 政和、小堀祥三、枇杷 剛、竹村 亨、 蓮沼祐子 $*$ 、桍田秀樹 $*$ 、堀内正公 $*$ 、七里元亮

【目的】我々は酸化LDLによるMф增殖において、 protein kinase C (PKC)が関与することを報告している(第28回日 本動脈硬化学会総会発表)。また最近、我々は酸化LDLに よるM增殖にはGM-CSF産生が重要であることを見いだ した(本学会発表予定)。そこで今回酸化LDLによるGMCSF産生におけるPKCの関与を検討した。

【方法】C3H/Heマウス腹埶M $中$ を用い、(1)M を添加し、細胞数測定、放射性チミジンの取り込みを增 殖の指標として検討した。(2)Mфに酸化LDLを添加し、 PKC活性の変化を検討した。(3)PKC阻害剤（カルホスチ ンC）の酸化LDLによるM增殖に対する影響を検討した。 (4)M $\phi$ に酸化LDLを添加し、培養上清中のGM-CSF浱度を 測定し、これに対するPKC阻害片の影響を検討した。

【結果】(1)HDL、LDLおよびACLDLにはM增殖活性は認 められなかったが、酸化LDLは濐度依存性に增殖を誘導 した。(2)PKC活性は酸化LDLにより一過性に上昇した。 (3)PKC阻害剂は瀑度依存性にM中增殖を抑制した。(4)酸 化LDLは濐度依存性にGM-CSFを産生し、このときPKC 阻害剂はGM-CSF産生を抑制した。

【結論】酸化LDLによるマウスM增殖において、PKCを 介するGM-CSF産生の関与が示唆された。 


\section{2 若年者動眼硬化性病変の㛟即 -PDAY Study-}

\section{1)旦本大学第二病理学教室、2)シカゴ大学病理部門}

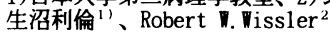

【目的及び方法】米国PDAY(Pathobiological determinants. of A therosclerosis in Youth) 研究のため採取された、15-34才の若

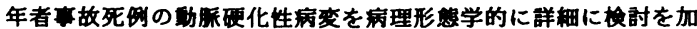

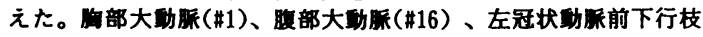
（\#45）をPDAY standar sample として用いた。扁怒を肉眼的に (1)Fatty streak:FS (2)Fatty plaque:FP(3)Fibrous plaque:FBP に分類し、さらに(2) を0i1-red 0 染色にて以下の4 つの組就

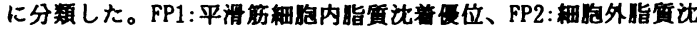

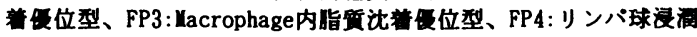
型。【結果】\#1と\#16 を比校すると、\#1のFS数は\#16 の約2 倍を 示した。FP1 及びFP3 数も\#1の方がより多く含んでいた。一方、 FP2 数は、\#16 の方が約2 倍多かった。FBP は\#16 に开的的に多 かった。\#45 のFBP 数は\#1、\#16 に比して明らかに多数を示した 实群群の約70x、高Chol esterol 群の的50x において、左冠状動

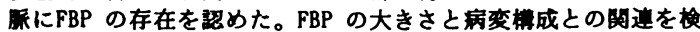
討すると、小型のものにFat/Cholesterol core部面称が多く、大 きくなるにつれFibrous cap の厚さが增していった。【結詥】腹

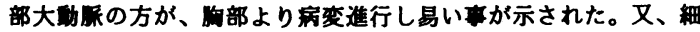

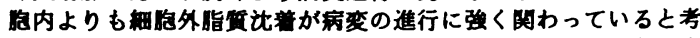

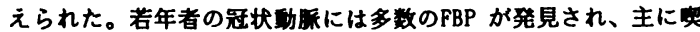
電により促進されると思われた。さらに小型の方がしろFBP の

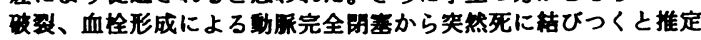
された。
153 桅尿病の合併をみる冠動脈硬化病单の特異性、特に心筋梗 塞発症との関連性

日本医科大学 病理学教室

福本裕子、思田宗彦、郭 方、横山宗伯、内藤善哉、 浅野伍朗

[目的] 功脈硬化症の成り立ちと心筋梗塞の発生の上で、榙尿病 合併の意義につき検討した。

[対象と方法] ヒト剖検例を用いて、I.対照群、II.NIDDM糖尿病群 III.心筋梗塞群、IV.NIDDM榶尿病合併心筋梗塞群に分け、各症例 の冠功脈より標本を採取し、光䫓的、電顥的観察に加えて、免疫 組樴化学的に抗 $\alpha$ 平滑筋アクチン抗体、抗マクロファージ抗体 (C D68)、抗テネイシン抗体、抗TGF- $\beta$ 抗体の局在及びTUNEL 法にてapoptosisの発現の状態を検討した。

[結果] 対照群に比へ、心筋梗塞群では、内朕率の增加、 $a$ アク

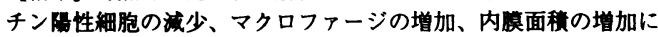
伴うテネイシン淂性面滞の相対的低下が見られた。榙尿病群では、 内模率、マクロファージの增加に差が認められなかったが、 $\alpha$ ア クチンとテネイシンの局在には增加が見られ、雨者に正の闍連性 が認められた。そして、楉尿病合併心筋梗塞群では、他の群に比 ベ、テネイシンの局在とマクロファージの泡沫化が顥著になり内 改篍性変化が増強していた。また、この榶尿病合併例のII群と IV群では、TGF- $\beta$ の局在が内皮細胞とテネイシンの陽性領域の

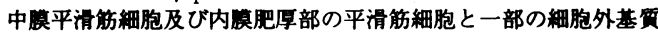

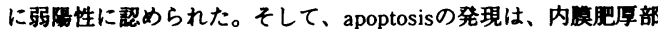

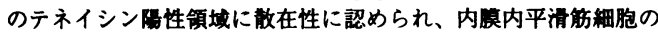
脱分化が示睃された。

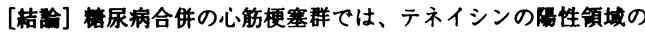
平消節細胞及び一部の細胞外基兵にTGF- $\beta$ ，が弱淂性に被められ、 血管の細胞外基要の産生の促進が心筋梗塞の発生促進因子として 重要であることが示唆された。
154

$$
\begin{aligned}
& \text { ヒト冠状動脈硬化然における i N O S の存在とその役割に } \\
& \text { 関する検討 } \\
& \text { 名古座大学医学部老年科学江崎貞治、林登志雄 } \\
& \text { 武藤患美子、井口昭久 }
\end{aligned}
$$

（目的）郋脈硬化発症には慢性资症と多くの類似点が認め られ、Tリンバ球とマクロファージはの主要な役割を担 っていると推测される。我々は、昨年の本学会において、

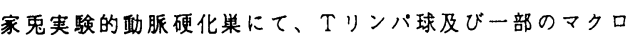

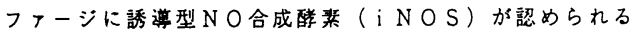
ことを報告した。今回は剖検標本を用い、と卜冠状動脈硬 化果を中心に检郡を行なった。（方法）死後 3 時間以内に 剖検か可能だった症例を用い以下を検討した。抗 i N O S 抗体、抗 P C N A 抗体、抗F a s 抗体、抗 Tリンバ球抗 体、抗、クロフフージ抗体、抗平滑筋抗体に上万免疫租織 架色を行ない、局在について検討した。（結果）ヒ卜冠状

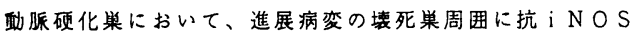
抗体で染色される部分を認め、抗 Tリンパ球抗体で染色さ れる部分にはは一致し、抗平滑筋抗体による染色部位とは 異なっていた。また、i NOS 染色部位の多くは、抗P C $\mathrm{NA}$ 抗体及び抗 $F$ a s 抗体で染色された。動脈硬化の認め られない部分には、抗 i NOS 抗体で染色される部分は認 められなかった。（結論）ヒ卜冠状動脈硬化巣においてT リンバ球及びー部のマクロファーシに一致してi NOSか 誘道されていることが示唆された。この、i NOSは動脈

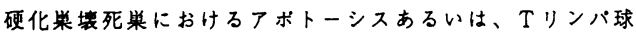
及マクロファージの增殖制御に関与している可能性が示唆 された。

155 高コレステロール負荷ウサギの躬状動脈硬化病変にお けるアポトーシスの役割

岐皁大学第二内科 国島明久、鹰津久登、竹村元三、早川幸博、 藤原久義

京都女子大学、藤原兌子

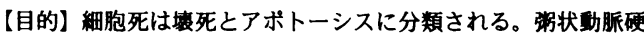
化（plaque）の進展と共に泡沫細胞は死に至る。この泡沫細胞の 死がアポトーシスによるという仮説のもとに実験的動㟲硬化病変 におけるアポトーシスの有無について検討した。

【方法】雄 New Zealand white rabbitを用いて1\%コレステロール負 荷群 12 羽と対照群 12 羽を作製。3および5ヶ月後（各群6羽）に上 行大動脈と暊動脈を取り出し、一部を電影固定、残りを $10 \%$ 中性 ホルマリンにて固定した。アポトーシスは光顠 (in situ nick end labeling (TUNEL) 法) ならびに雨影的に検討した。またマクロ ファージ、平滑觔アクチンならびにbcl-2蛋白（アポトーシス抑制 因子）を免疫組織学的に検討した。

【結果】コレステロール負荷5力月群では動腺硬化巣は負荷 3 力月 群の約3倍の面栍に達し、plaque内に多数の泡沫細胞と死んだ細胞 を認めた。またplaque内の大部分の細胞はマクロファージ由来で あるが、平滑筋細胞も中膜および内膜の内皮細胞直下に認められ た。TUNEL淂性核はコントロールおよびコレステロール負荷 3 カ 月でゼロに対し、負荷5力月群で5/6列にみられた。電顆において マクロファージ由来ならひれ平滑肪由来の泡沫细胞に核物貫数集、 apoptotic body等のアポトーシスの像をコレステロール負荷5力月 群に礁認した。Bcl-2蛋白は中膜および内皮絧胞直下の平滑筋で 助性であったが、マクロファージ由来の泡沫細胞は染色されなかっ た。

【結語】助胍硬化巣の進行と共にアポトーシスが增大するので泡 沫細胞の死にアポトーシスが重要な役割を演ずると思われる。 
156

高脂血症ラットの大動脈硬化発生初期における接着分子 ICAM-1/LFA-1の役割について

$$
\text { ニ五 }
$$

筑波大学基礎医学系病理学 聶 青, 原岡誠司, 范江箖, 渡辺照男

【目的】動脈硬化発生初期では、白血球の内皮細胞表面への接着 - 内皮 下への侵入および包沫細胞化が重要とされている。しかし、その機序に ついてはまだ十分に解明されていない。我々は高脂血症ラットを用いて 単球、Tリンパ球の内膜浸潤における接着分子ICAM-1/LFA-1の作用 を検討した。【方法】雄Fisher 344ラットを用いて、高コレステロール 食朗を 10 週まで負荷した。これらのラットを潅流固定して、大動脈を 切り出し、腹部大動脈を中心として、動脈硬化病変の免疫染色並びに電 顕観察を行った。また、我々が開発したen face double immunostainingを用いて、単球、Tリンパ球を同定・定量化し、接着分子 ICAM-1/LFA-1の発現及び機能を検討した。ICAM-1の役割につい て、高コレステロール血症ラットに抗ラットICAM-1 mAb(3mg/body weight $/ \mathrm{kg})$ を 2 週間腹腔内に注射した。【結果】1)ラットに高コレステ ロ一ル食郎を負荷すると、単球、Tリンパ球の内皮細胞への接着と内皮 下への浸潤が発生した。 4 週後の初期病変では、腹部大動脈に浸潤して いたTリンパ球および単球の割合はそれぞれ総細胞数の $28 \%, 72 \%$ 占めた、 10 週後にはマクロファージ $(\mathrm{M} \phi)$ の泡沫化による脂肪斑が形成 され、この時期においてはMфの比率は90\%に達した。2）LFA-1を発 現したTリンパ球とMфの数を調べるためにLFA1とMd(抗ラットED $1 \mathrm{mAb})$ のen face double immunostaining を行った。浸潤した細胞に対す るLFA-1陽性紏胞の割合は 4 週では $84 \% 、 10$ 週では $92 \%$ であり、い ずれの時期においてもLFA-1陽性細胞が優勢であった。LFA-1のリガンド であるICAM-1の腹部大動脈における発現は病変好発部位であるceliac arteryの分岐口周囲に高度であった。3）抗ラットICAM-1 mAbを 2 週 間腹腔内に注射したラット群のTリンパ球及びMの数は対照群よりそれ ぞれ $14 \% 、 45 \%$ 減少した。特に、LFA-1陽性Tリンパ球とM\$が $49 \%$ の減少を示していた。【結論】動脈硬化の初期発生にICAM-1/LFA-1が 重要な働きをしていることが示唆された。

157

Vascular Dendritic Cells in Human Atherosclerotic Lesions

筑波大学基礎医学系病理 Y.V. Bobryshev，渡辺照男

Ultrastructural analysis of serial sections of human aortic intima revealed the presence of cells with typical dendritic features, which we designated as vascular dendritic cells (VDCs). VDCs are immunohistologically positive for CD1a, S-100, HLA-DR antigens and detected more frequently in atherosclerotic lesions than in normal artery intima. In this study, we examined the cellcell interactions of VDCs with T lymphocytes and macrophages in human atherosclerotic plaques of the carotid artery and aorta, by electron microscopy and double immunostaining for $\mathrm{CD} 1 \mathrm{a} / \mathrm{CD} 3$. S-100/CD4, S-100/CD8 and S-100/CD68. We found that in atherosclerotic plaques, more than $80 \%$ of VDCs interacting with T-cells located in the areas associated with neovascularization and inflammatory infiltrates. However, VDC/macrophage interactions were not associated with apparent neovascularization but, rather abundant around the necrotic core where most destruction processes occur. The presence of a large number of $\mathrm{VDC} /$ macrophage contacts in these areas indicates that these interactions may be essential for immune process in atherogenesis. In addition, VDCs lack endophagocytic activity and lysosomal activity, therefore, VDC/macrophage cooperation might compensate for these VDC functions. The small number of VDC/T lymphocyte interactions around the necrotic core suggests that VDCs migrate to other areas where the microenvironment allows the T-cell/NDCs interactions in order to present antigens collected around the necrotic core.

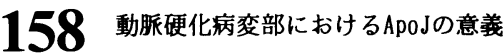

群馬大学医療短大 ${ }^{1}$, 日本抗体研究所 ${ }^{2}$, 昭和大学薬学部 ${ }^{3}$ ${ }^{1}$ 鈴木㦄二, ${ }^{2}$ 中嶋克行, ${ }^{2}$ 中野隆光, ${ }^{3}$ 三浦虎南, ${ }^{3}$ 富田基郎

【目的】Apolipoprotein(Apo)Jは血液中では HDLの構成蛋白て あるが, 多様な腈器組織細胞で産生される物質で, 動脈壁での局 在が報告されているが，その意義については充分解明されていな い。われわれは大動脈壁におけるApoJについて検索した。

【方法】1歳から90歳の71例の大動脈を剖検時採取し, 動脈壁に 局在するApoJ，ApoA-1,ApoB, ApoEやアクチンについて免度組綼化 学的に検索した。【結果】ApoJは内膜，中膜の両者に局在し，若 年例においてもApoJは認められ，加勘的に多くなっていた。ApoJ は内膜および中膜平滑筋細胞の細胞質に局在が認められたが, 多 くのApoJは細胞外の基質や線維に局在していた。ApoJは中膜より 内膜に多く沈着し，強い䶻着を示した部をアクチン染色するとAp 0Jの多い所にアクチン染色陽性細胞はなく，ApoJit着の弱い部で はアクチン陽性筋細胞が多数認められた。動脈におけるApoJ以外 のApOA-1, ApoB, ApoEともにApoJと同様に内膜, 中膜に局在してい たが,ApoA-1は中膜における局在は極めて少なく,ApoE はApoJと 同様の染色態度を示した。

動脈病変部の線条脂肪斑ではApoJは泡沫細胞周囲の細線維に泃 着していたが泡沫細胞には局在していなかった。線維性プラーク では内膜の膠原線維にApoJが著明に沈着していた。帮状便化巣で はアテローム内へApoJが多量に沈着し，アテロームの周囲の膨化 した翏原線維に多量のApoJが沈着していた。中膜にもApoJの多量 の沈着がみられたが, 栄養血管周囲にはApOJは認められなかった 。【結論】ApoJの大部分は血液中より内膜および中膜に沈着した もので，筇細胞によるApoJの産生は少ないと思われる。ApoJは内 膜の楾維化に伴って沈着しており, 内膜の線維增生や膠原線維の 胈化に関与すると考えたい。

家鬼大動脈バルーン傷害モデルにおける組織因子 発現の検討

宮崎医大第一病理 1 、化学及血清療法研究所 2

畠山金太 1 、浅田祐士郎 1 、佐藤勇一郎 1 、住吉昭信 1 、神寉勇一 2

（目的）近年、邪状動脈硬化巣において外因系血液凝固因子の一 つである組穖因子 (TF) が異常発現されていることが報告されてお り、動脈硬化巣の形成ならびに合併病変、特に新腫破綻に続く血栓 形成への関与が示唆されている。今回我々は、家鬼大動脈バルーン 伤害モデルにおける TF 発現の変化を検討したので報告する。

(方法) 日本白色家鬼にバルーンカテーテル $(4 \mathrm{~F})$ を挿入し大動 脈の内皮細胞を剥離し、術後 1 時間 8 週間で屠殺した。胸部大動 脈を採取し免疫染色及び免疫電顕を行った。用いた抗体は抗TF抗 体、抗平滑筋細胞抗体 (HHF-35)、抗マクロファージ抗体 (HAM56) 及び抗内皮細胞抗体である。また発現しているTFの Factor VIIa との結合能の有無を調べるために、ビオチンあるいはジゴキシゲニ ン標識Factor VIIaを作製しスライド切片上で反応させ免疫組織学的 に検討した。さらに大動脈を外膜と中膜および内膜に分け、各々に ついて TF mRNA 発現量の変化を Northern blotting 法で検討し、TF mRNAの局在については In situ hybridization 法にて観察した。

(結果) 家鬼大動脈バルーン傷害モデルにおいては、肥厚内膜及 び中膜内層の平滑筋細胞に強いTF発現が認められた。また発現し ている TFは Factor VIIa との結合能を有していた。

(結論) 動脈硬化巣での血栓の形成に、平滑筋細胞が産生するTF が関与していることが示唆された。 
160 Benazepril の実駼的動脈硬化に対する影箵 3

鹿應美哇大学医学部老年科、帝京大学菜学部微生物病態生化学教室、慶應義 熱大学医学部病理学教室、東京電力病院病理

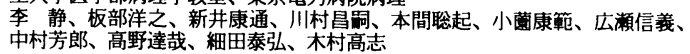

【目的】家鬼にコレステロール負荷による実験的動脈硬化を作製し Benazepril の影響を㛟討した。前回我々は1）進行病変では平渭筋細胞は内皮下および内 膜深部に、マクロファージは内膜中部に存在する、2）PDGF，TGF膜梁部にのみ存在することを報告した。今回我々はマクロファージの遊走、活 性化に関与する酸化LDLおよびMCP-1 の局在と併せて apoptosisについて も検討したので報告する。

【方法】New Zealand white rabbitに2\%コレステロールを負荷した (C 群)。このうち半数にBenazeprilを $3 \mathrm{mg} / \mathrm{kg}$ を連日投与しB群とした。12週 後に屠殺し大動脈を摘出し一般染色と併せて免度組織学的检討を行った。抗 体は抗酸化LDL抗体、抗 MCP-1 抗体を用い、さらにapoptosis の検討も行 った。

【結果】1. 酸化LDLは初期病変では内皮下に広範囲に存在したが進行病変で は深部に局在しほぼマクロファージと同じ分布を示した。B群では酸化LDL の分布はC 群と同じであった。2. MCP-1 は初期病変では主に内皮に局在し たが、進行病変では内皮および内膜中深部にかけて局在した。B群では内皮に おける MCP-1の分布はC 群に比較し少なかった。3. PCNA 陽性細胞及び apoptosis陽性細胞の局在はほぼ同じ分布を示した。すなわち初期病変では内 膜全層において、進行病変では内皮下及び内膜深部に分布した。B群では陽性 細胞の存在は少なかった。

【考察】B群の初期抦変では酸化LDLの分布はC 群と同じであったが、MCP1 はB群ではC群に比較し発現が低かった。これはBenazepril は酸化LDLの 生成、蓄積には影響を与えないが、MCP-1 の生成を阻害する可能性があるこ とを示唆する。PCNA および apoptosis 陽性細胞の分布が同じで細胞分裂が 盛んな部位では細胞死も起こりやすい可能性が示唆された。Benazepril は細 胞增殖及び細胞死を減少させた。

161

高速螺旋 C T搭载検診車を用いた冠動脈石灰化

の検出と冠危険因子との関係について 千葉大学第三内科 伊谷崇崇 田口理恵 丹野美穭 井上雅裕 大西正記 高須淮一郎渡辺滋增田善昭 結核予防会千莱県支部角南祐子志村炤光 放射線医学総合破究所宫本忠昭

【目的】高速螺旋 C T 搭載検診車による冠動脈石灰化の検出を 行い、冠危険因子との関係について検郡する。【方法】肺癌およ び肺結核検診の目的で結核予防会千葉県支部において行われた高 速螺旋 C T検查を受けた 447 名(男性 225 名、女性 192 名、平均年 齢 52.6 歳)の住民を対象とした。日立メディコ製のC T - W950 $\mathrm{SR}$ を使用し、肺尖部から横隔膜までの約 30 スライスを 30 秒間 一回の息止めでスキャンした。そのうち冠湖脈の見られる5〜7 スライスで冠動脈のC T 值を測定し、+110HU 以上を石灰化有 所見として、冠動脈石灰化と冠危険因子(年齢、性別、高血圧歴、高 脂血症歴、糖尿病歴、喫煙歴、飲酒歴)および虚血性心疾患、脑血管 疾患の有無との関連について検討した。【結果】冠動脈石灰化は 447 名中 37 名 $(8.3 \%)$ に認められ、枝別、枝数別、年齢、性別每 の石灰化の頻度は昨年の本学会での報告とほぼ同様であった。冠 危険因子の中では虚血性心疾患、哭煙歴、高血圧歴、性別、年齢 と冠動脈石灰化との関連が認められた。特に虚血性心疾患を有す る 12 名中 4 名に石灰化を認め、最も高いオッズ比を示した。 【結語】高速螺旋 C T 搭载検診車による一般住民の胸部検診にお いても冠動脈石灰化の検出は虚血性心疾患のスクリーニングに有 用であると考えられた。

\section{MTHFR、アポE、アポ(a)の迹伝的多型の組み合わせと}

筑波大学基碟医学系遣伝医学 ·小林公子、歐 怡文、有波忠雄、 浜口秀夫

土浦協同病院内科・雨宮 浩、福岡大学第二内科・朔 啓二郎

【目的】血槳中のホモシスティン浱度の上昇が、虚血性心疾患のリ スクファクターのひとつとして注目されている。最近、血整中の木 モシスティン灌度の上昇と関連する methylenetetrahydrofolate reductase (MTHFR)速伝子のミスセンス多型（C677T、Ala $\rightarrow \mathrm{Val} ）$ が同定され た。本研究では、このミスセンス多型と虚血性心疾患との関連、お よびアポリポタンパク E（アポE）またはアボリポタンパク(a)（ア ポ(a)）の遗伝的多型とMTHFR速伝子型の組み合わせと虚血性心疾 患との関連を明らかにすることを目的とした。

【対象および方法】65歳前に虚血性心疾患を発症した患者187名お よび、健康な人間ドック受診者263名について、MTHFR、アポEお よびアボ(a)の遗伝的多型を分析した。

【結果】虚血性心疾患患者群におけるMTHFRのT677の木モ接合体 の頻度、およびアボE4または小さいサイズ $(660 \mathrm{kDa}$ 以下、推定ク

リングル4 数 24以下) のアポ(a)を保有する個体の頻度は、虚血性 心疾患患者群ではコントロール群のそれに䡈べて有意に增加してい た (MTHFR : $23.5 \%$ vs $10.3 \%$ 、p $<0.001$ 、アポE : $24.9 \%$ vs $17.4 \%$ 、

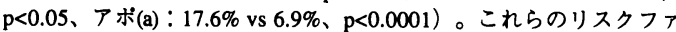
クターの租み合わせと虚血性心疾患との関連を分析したところ、 MTHFRのT677のホモ接合体が、アポE4または小さいサイズのアポ (a)を保有すると虚血性心疾患に対するOdd比がそれぞれ5.5

(95\%CI:1.8ー17.0) または13.1（95\%CI:1.6ー107）に上昇した。

【結語】MTHFRのT677のホモ接合体が、アボE4遗伝子、または小 さいサイス（660kDa以下、推定クリングル4 数 24以下）のアポ(a) を保有すると虚血性心疾患に対する遣伝的危険率が上㫒することが 示唆された。

163 冠動脈疾患に㧍けるLDL分画中の脂肪酸組成

$$
\begin{aligned}
& \text { 順天堂大学㡒環器内科大村宽敏渡辺嘉郎 } \\
& \text { 代田浩之圭野浩司初見殙恵 } \\
& \text { 横井尚桜井秀彦山口洋 }
\end{aligned}
$$

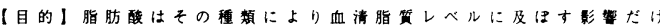

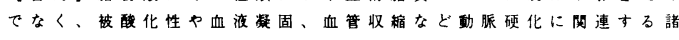

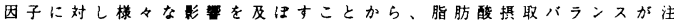
目されている。今回、我々はLDL分画中の脂肪酸組成と冠動脈疾 患との闌連について㛟討した。【方法】对象は冠動脈造影を施行し た、 40.70 瓷(平均年令 59 藏、男女比 $49 \mathrm{vs} 12$ )、高脂血症治 療菜未服用の 61 例。冠眽造影上、50\%以上の有意狭窟病变の有 無でCAD+群( 44 例) と CAD群(17 例)に分けて検敦した。超遠心

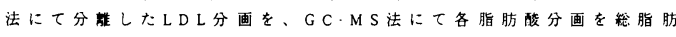
酸比(\%)で算出した。【結果】2群間で年令、性別に差は無かった。

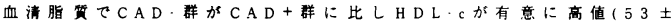
$18 \mathrm{vs} 43 \pm 13 \mathrm{mg} / \mathrm{d} 1)$ 示した。LDL分画中の脂肪組成沬

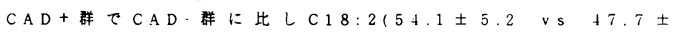

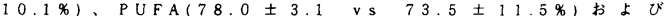
$\mathrm{n} \cdot 6 / \mathrm{n} \cdot 3$ 脂肪酸比 $(6.0 \pm 2.2$ v s $4.8 \pm 1.3)$ 占有意上高值示

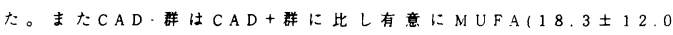
vs $13.8 \pm 2.3 \%)$ 䯩值を示した。C18:1およびn.3系脂肪酸に ついての2群間の差は認められなかった。また、各脂肪酸と血清脂

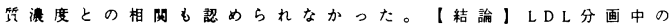
PUFA、特にその主要棈成成分であるC18:2が冠動眽硬化に促進 的に、MUFA が㧕制的に作用している可能性が示惨された。n.3采

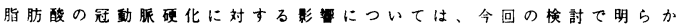
にされなかったか、 $\mathrm{n} \cdot 6 / \mathrm{n} \cdot 3$ 脂肪酸比が CAD+群で高值であるこ とより、PUFAの中で $\mathrm{n} \cdot 3$ 系脂肪酸の占める比が增加することで、 冠動眼硬化に对し抑制的に作用する可能性し示唆さ机了。 


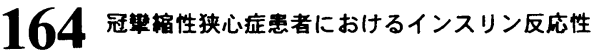

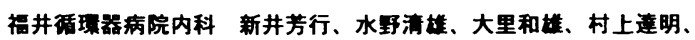
守内郁夫、丹尾裕、郭 文治、离满美文、大中正光

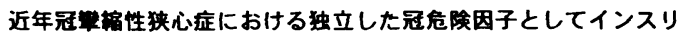
ン抵抗性が報告されているか、その臥価は定まっていない。【目

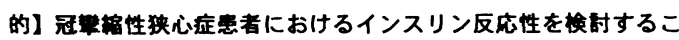

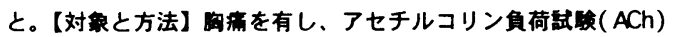

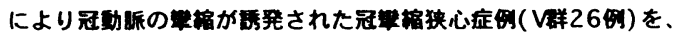
狭心症例(VAP群21例)，心譄梗基を発症し、ACh隭性であった

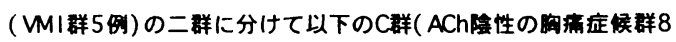
㤡)、MI群(心觔梗基を発症し、ACh隆性であった群10例)を対

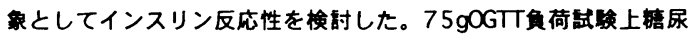

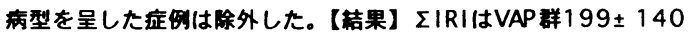
$\mu \mathrm{g} / \mathrm{I}(\mathrm{p}=0.002)$ 、VMI群 $188 \pm 34 \mu \mathrm{g} / \mathrm{I}(\mathrm{p}=0.0006)$ 、MI群 $208 \pm 126 \mu \mathrm{g} / \mathrm{I}(\mathrm{p}=0.01)$ でありC群の87 $\pm 31 \mu \mathrm{g} / \mathrm{l}$ に比して有 意に高值だった。 $|R|$ |の平均值は、VAP群とVMI群でほほ同一 であったか、VAP群の $\Sigma|R|$ は22 537 $\mu \mathrm{g} / \mathrm{l}$ と螎広く分布し、 $100 \mu \mathrm{g} /$ 满の症例も9例存在し、高値群と低值群の二性のビ

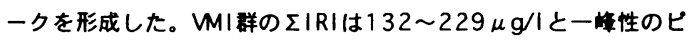

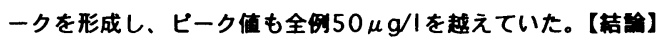

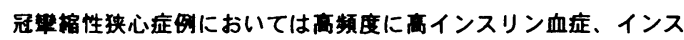
リン抵抗性䚮存在し、VII群に㩆著だった。VAP群には正常反応

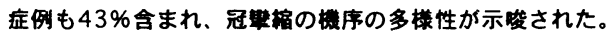

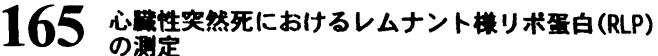

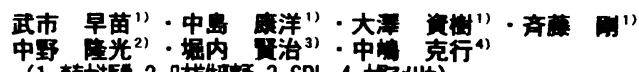

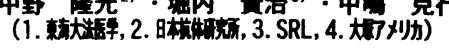

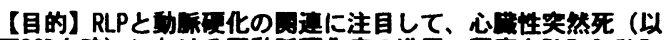

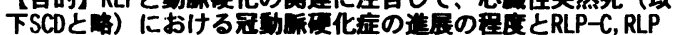
-TGの血福度ならひにアポEのフノタイフととの正につい て唋したので紫告する。

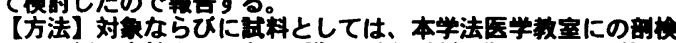

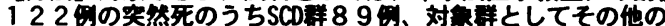

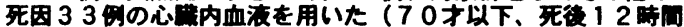
以内)

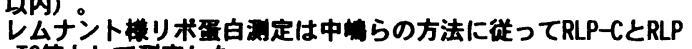
-TGとして淀した。

【拮果】 RLP-TGは $100 \mathrm{mg} / \mathrm{dQ}$ 以上、RLP-Cは $10 \mathrm{mg} / \mathrm{dQ}$ 以上

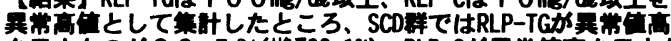

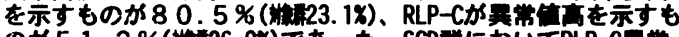

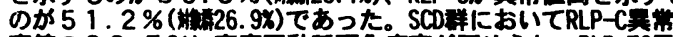

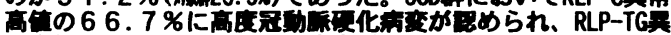

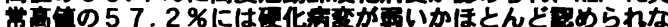

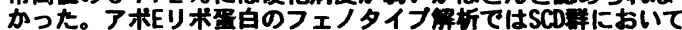

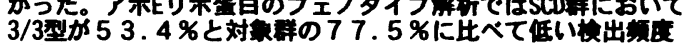
であった。

\begin{tabular}{|c|c|c|c|c|c|}
\hline & SCD & & Cont & & P. value \\
\hline 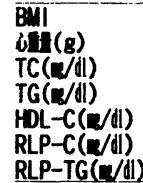 & $\begin{array}{r}22.9 \pm \\
396.9 \pm \\
203.9 \pm \\
398.9 \pm \\
46.4 \pm \\
19.0 \pm \\
227.5 \pm\end{array}$ & $\begin{array}{r}3.7 \\
89.4 \\
82.3 \\
168.3 \\
18.2 \\
20.6 \\
163.7\end{array}$ & $\begin{array}{r}21.2 \pm \\
345.0 \pm \\
147.3 \pm \\
330.9 \pm \\
54.6 \pm \\
8.9 \pm \\
95.8 \pm\end{array}$ & $\begin{array}{r}3.6 \\
85.0 \\
69.8 \\
195.4 \\
23.7 \\
8.0 \\
85.4\end{array}$ & $\begin{array}{l}\text { N.S. } \\
<0.01 \\
<0.001 \\
\text { N.S. } \\
\text { N.S. } \\
\text { N.S. } \\
0.001 \\
<0.001\end{array}$ \\
\hline
\end{tabular}

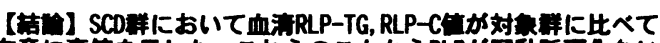

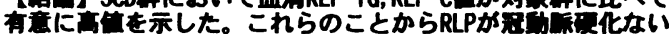

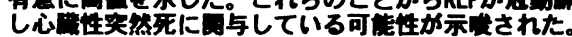

166 脂肪肝と動脈硬化の関連性の検討 : 第二報 血中remnantlike particles cholesterol (RLP-C)の意義に関して 東京女子医科大学付属青山病院・同成人医学センター1 東邦大学医学部付属大森病院臨床生理機能学 ${ }^{2} 、$ 同ME部 ${ }^{3} 、$ 日本抗体研究所 ${ }^{4}$

栗原 毅、岳マチ子、前田 㿞、重本六男、山下克子、横山 泉 ${ }^{3} 、$

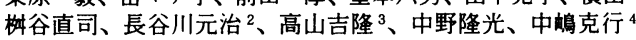

【目的】第28回本絵会で脂肪肝の5年間のfollow up study及びRLP

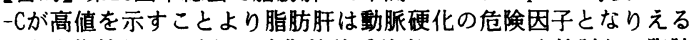
ことを指摘した。今回、定期検猃受診者でのRLP-Cを検討し、脂肪 肝之動脈硬化の関連性を探った。同時に、全例で他の危険因子と の相関を探り、検影におけるRLP-Cの臨床的意義の検討も加えた。 【方法】定期検部受部者 1,000 例 (男性700例、女性300例) を対象之 した。平均年齢は60.7歳 (男性60.9歳、女性60.4歳)であり、脂肪 肝の診断は超音波検査によった。RLP-CはUV醉素法で測定し $5 \mathrm{mg} / \mathrm{dl}$ 以下を正常値とした。成因別脂肪肝の分類は肥満群 (BMI26以上)、 糖尿病群 (FBS140mg/d1以上)、アルコール群 ( $\gamma$-GTP60mg/d1以上) 成因不明群、複数成因群とした。【成績】1. 脂肪肝の検討 : 頻度は $20.3 \%$ (男性 $16.7 \%$ 、女性7.9\%)であり、成因別では肥满群 $10.3 \%$ 、 糖尿病群 $15.8 \%$ 、アルコール群 $9.9 \%$ 、成因不明群 $49.8 \%$ 、複数成 因群 $14.3 \%$ であった。脂肪肝のRLP-Cは $6.4 \pm 10.4$ であり非脂肪肝 の4.2 4 4.8に比し有意に高值であった $(\mathrm{P}<0.01)$ 。特に成因別の群 間では有意差は認めなかった。2. 全例での他の危険因子との相関 (前、異常例・後、正常例) : i. T. C; $4.1 \pm 6.1 \mathrm{vs} 2.5 \pm 2.8$ ii. TG;6. 4 $\pm 7.1 \mathrm{vs} 1.8 \pm 1.3$ iii. LDL-C;4. $0 \pm 5.6 \mathrm{vs} 2.2 \pm 2.6$ (以上P<0.001) iv. HDL-C;5.5 $5 \pm 3.2$ vs2. $7 \pm 3.2(\mathrm{P}<0.01)$ v. BMI $; 4.4 \pm 9.7 \mathrm{vs} 2.8 \pm 3.4$ vi. FBS; $3.4 \pm 3.9 \mathrm{vs} 2.9 \pm 4.3$ (以上N. S).【結論】今回は多数例で検 討したがやはり脂肪肝で高率に高レムナント血症を認めた。年間 のfollow up studyの結果を合わせると脂肪肝は動脈硬化の危険因 子となることが再認識された。1,000例全例での他の危険因子とRLP 一との関連性ではコレステロール、HDL-C、LDL-C、TGと相関したが 肥満、血糖値とは相関を認めなかった。

167 高血压患者における高トリクリセリド血症について - - - 钦酒の影雾 -..--

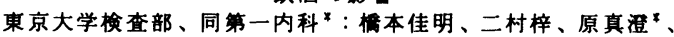

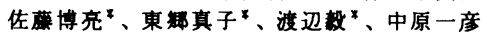

【目的】高血圧に高トリクリセリド血症が合併しゃすいこと が知られているが、この機序に関しては明かではない。飲酒 によりrGTPが上年する者は、飲酒により血圧も上昇しゃすい ことが報告されている。今回、炏酒習慣とrGTP、血压、血清 トリクリセリドの成俰を、他の成連因子を堣整して検討した。 【方法】对象者は20-59才の健診受診男性て、高血压、椐尿病、 高脂血症の服薬治㑊中の者を除く3541名である。高血圧は収 縮期血压 $\geqq 140 \mathrm{nnHg}$ 、または拡張期血压 $\geqq 90 \mathrm{nn}$ H とした。平均 值の比较はStudent's t-testて、闲因子(年踰、肥消度、

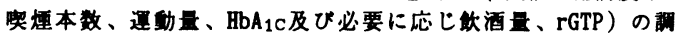
整と整啳の平均俌の比㜞はSASの回煸モテルで行った。

【桔果】钦酒習慣のない者 (462名)ては、トリクリセリド、r GTP は、正常血压群 (406名) と高血圧群 (56名) の間に有意差は 認められなかった。一方、炊酒習慣のある者（3079名）では、 领酒量を詷整しても、高血压群 (513名)て、トリクリセリドと rGTPが有意に高値でっったか、さらにrGTPでも調整するとト リクリセリドに有意差は竲められなくなった。次酒習慣のあ 万者を、高rGTP群（ $240 \mathrm{IU} / 1)$ と正常rGTP群（<40IU/1）に 分け比㜞すると、飲酒量を誠整しても、高rGTP群で有意に血 压とトリクリセリドが高値であった。この正常rGTP群は、歕 酒習慣のない者全体と比㜞しも、执張期血压やトリクリセリ ドには有意差は認められなかった。

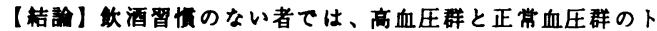
リクリセリド值に有意差はなく、高血圧群てトリクリセリド が高值である原因は、高血圧そのものではなく领酒である可 能性がある。 


\section{8 䅡動脈硬化に影等を及はす各種リスクファクターの检討}

京都工場保健会 ${ }^{1}$ 、京都府立医科大学第二内科

森口次郎”、伊東宏、木山昌洋、八田告、河哲吉、三木茂行、

森本聡、中村和恵、中田徽男、佐々木享、武田和夫、中川雅夫

【目的】钦脈硬化へのリスクファクターの関与を検討するため、 頚動脈エコーを用いて頝動脈の内膜・中䐉厚 (IMT)と pl aque所見 を観察し、各種リスクとの関連について検討した。

【方法】対象は95年12月から96年2月の間に当会にて預動脈エコー を施行した547名で、高血圧症（359名）、高脂血症（222名）、 栯尿病（197名）、虚血性心疾患（76名）、脑血管障害（58名） にて投薬または一般療法を受けている患者を含む。年龄は16〜 93 崴（平均 58.9 嵅）、性別は男子 438 名、女子 109 名である。頝 動脈エコーを行い、総䅡動脈、内 ·外顏動脈、椎骨動脈の内径、 IMTの計惻及びplaqueの有無を锶察した。plaque score（PS）を用 いて plaqueの定量評価も行った。IMT、plaqueの有無、PS と、患 者の背景因子すなわち年齢、性、BMI、血圧、㔖煙指数、飲酒量、 血清脂質、合併疾患との阑を多変量解析を用いて解析した。更 に、左心室重量指数（LVMI）との関連についても検討した。

【結果】(1)基硞疾患として高血圧、桾尿病、脳血管障害、虚血 性心疾患がある場合、IMT、PSが大である傾向がみられた。(2) 重回㷌分析により IMTは年齢、収縮期血圧、喫堙を独立変数とし て相関がみられた。心エコー施行例での検討では、年龄、収縮期 血圧、乫煙、LVMIが独立変数として選ばれた。(3) PSは年龄と 乫煙と相関した。(4)plaqueの有無についてlogistic 解析を行うと、

年齢、総cholesterol值、製煙が有意な独立变数として挙げられた。

【結論】IMTは、年龄、収縮期血圧、乫煙、LVMI と、plaque は 年龄、捴 cholesterol值、㔚焐等と相関がみられ、いずれも虚血性 心疾患や脑血管障害を有する場合大きい傾向がみられた。高血圧 及び他の危険因子の動脈硬化への関与が直接的に示唆された。

\section{9 健常人における血清NOx瀑度の加龄変化と性差} 東京大学医学部老年病学数室、同医情報部*、杜会保険中央粉合病院* 杉本直太、秋下雅弘、神绮恒一、江頭正人、吉栖正堆、阿古调哉、長野 宏一朗、須雚紀子、㳊辺正江、鳥羽研二、木内貴弘、白川弥*大内尉義

【目的】 Nitric oxideの最終代瀻産物である $\mathrm{NO}^{2-}+\mathrm{NO}^{3-}(\mathrm{NOx})$ の血清濃 度正常值の設定と、血清NOx漫度の加龄变化と性差の検討。【方法】 像康診断受診者(平成8年1月の $1 \mathrm{~W} 、 \mathrm{n}=505$ )を対象とした。現病歴を有 するもの、およひ传診にて探血を行い、そのうち高血圧(SBP $\geqq 140$ ま

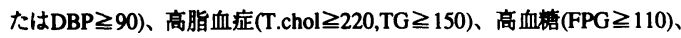
その他怪障害、肝障害、心電図異常なとの異常を認めた者を除外し た健常人263人(20〜69才)の血消NOx源度を測定した。なおNOxの分 布を正規化するため、統計解析は対数変換した值を用いた。加秢変

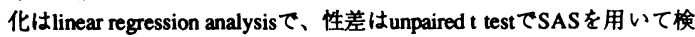
定した。また本測定法のCVは約3\%、回収事は約100\%であった。

\begin{tabular}{|c|c|c|c|c|}
\hline 【結果】 & & 女性 & & 男性 \\
\hline Age (yr) & $\mathrm{n}$ & meantS.D.(median) & $\mathrm{n}$ & meantS.D.(median) \\
\hline $20-29$ & 39 & $35.0 \pm 21.9(27.5)\rceil$. & 39 & $41.6 \pm 21.6(38.1)]$ \\
\hline $30-39$ & 29 & $44.2 \pm 21.2(38.0)]$ & 40 & لـ $51.6 \pm 25.0(47.5)$ \\
\hline $40-49$ & 34 & $45.5 \pm 25.7(41.1)$ & 34 & $47.1 \pm 29.7(38.1)$ \\
\hline $50-$ & 16 & $51.7 \pm 29.4(46.8)$ & 32 & $47.0 \pm 20.2(42.6)$ \\
\hline Total & 118 & $42.6 \pm 24.3(35.6)$ & 145 & $46.8 \pm 24.4(41.0)$ \\
\hline
\end{tabular}

女性では、血消NOx濩度は年龄とともに有意に增加した $(\mathrm{p}<0.05)$ が、 男性ては年哙との相関は認められなかった。また20〜39才の女性は 20〜39才の男性に比べて有意に低值であった $(\mathrm{p}<0.05)$ が、40才以上て は男女差は認められなかった。【結詥】血清NOx濩度には性差と加 跲変化が認められ、その值の解根には注意を要する。
170 アポ蛋白 A - I I の臨床的意義に関する研究 1。人間ドックでみられた高アポA－ＩＩ血症の臨床像 杏林大学医学部高齢医学 山本実 尾張裕美 原恵利子 丹野大 山村尚子 馬場賢哉 三島協二 中河原光 大貫仁士 水川真二郎 大荷満生 中島久実子 林潤一 秦臀哉

く目的>アポ蛋白Ａ－ＩＩはＨＤＬの構成アポ蛋白であるが、 機能に関しては不明な点が多い。そこでアポ蛋白AーIIの臨 床的意義を研究する第一歩として、人間ドック受診者における 高アポA - I I 血症の臨床像を低アポA - I I 血症と比較した。 く对象ならびに方法〉対象は当人間ドックを受診した男性 29 2 名、女性 177 名の中で、A - I I が $45 \mathrm{~m} \mathrm{~g} / \mathrm{d} 1$ 以上を 示した男性 43 例（平均年齢 $46 \pm 11$ 歳、A - I I の平均 5 $0 \pm 5 \mathrm{~m} \mathrm{~g} / \mathrm{d} \mathrm{l}$ ) 、女性 18 例（50 $0 \pm 9$ 歳、 $48 \pm 3 \mathrm{mg}$ ／d１）を高アポA-I I 血症とした。逆にA－ＩＩが $30 \mathrm{~m}$

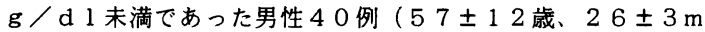
$\mathrm{g} / \mathrm{d} \mathrm{l}$ ) 、女性 33 例 (4 4 111 歳、 $27 \pm 2 \mathrm{~m} \mathrm{~g} / \mathrm{d} \mathrm{l}$ ) を低アポA - I I 血症とし、男女別に両群の臨床検査値を比較 娭討した。尚アポ蛋白は免疫比濁法にて測定した。

く結果〉高アポA－ＩＩ血症において有意に高値であった検査 項目は、男女とも総コレステロール、トリグリセライド、H D Lーコレステロール、アポA-I、B、C - I I 、 C - I I I 、 E、GOT、コリンエステラーゼ、総蛋白、アルコール摃取量 であった。男性では更に尿酸、 $\gamma$ G T P 、 G P T、L A P が高 く、逆に $\mathrm{B} / \mathrm{A}$ - I 比, 動脈硬化指数が低値であった。また女 性ではＬＤＬーコレステロール、ヘモグロビン、血圧が高値で あった。

く結論＞以上のように高アポA－ＩＩ血症では血清脂質、アポ 蛋白、尿酸が高値で、肝機能障害が認められたことより、アポ 蛋白 A - I I は脂質代謝異常や肝機能障害の指標になる可能性 が考えられた。

\section{1 小児期の身長別タイプ分類による危険因子の検討}

\author{
東京女子医大第二病院小児科 \\ 川野辺重之、藤田幸子、山崎公恵、村田光範 \\ （財）東京都予防医学協会 山内邦昭
}

【目的】小児期加らの成人病予防という観点から心血管疾患予 防対策として動脈硬化危険促進因子（以下危険因子）のスクリー ニングが全国規模でなされている。この健診において危険因子 の一つの肥満に関しては検討されているが身長という因子は検 討されていない。身長と高血压、高脂血症といった危険因子と の関係について検討した。

【方法】対象は平成 $5 、 6$ 年度に小児成人病予防健診として全 国 28 都府県で行われた小学校 $4 、 5$ 年生、中学 1 年生、高校 1 年生の計 33,259 名である。小児成人病予防健診実施方法に則っ て全員に身長、体重、血圧測定、血液栓查 (総コレステロール： TC) を実施した。検診の結果より男女別、学年別の身長の偏 差值を求め、 $\pm 1 \mathrm{SD}$ 以内標準身長の群、-1SD未満の低身長の 群、+1SD以上の高身長の群の3群に分けてそれぞれの高血圧、 高脂血症 (高TC血症) の出現頻度の検討を行った。また、肥 満なし(肥满度20\%未満)、肥満あり（肥満度30\%以上）の各 群における検討も行った。

【結果】高血圧、高脂血症ともに肥満ありの群で有意に発生率 が高い。高血圧は高身長のグループにその発生率が有意に高く、 高脂血症は低身長のグループに有意に高い。

【結論】危険因子としての肥満は高血圧、高脂血症の合併率が 高く、重要な因子であるが、現在行われている健診では身長の 因子は考虑されていない。肥満なしの群の内でも低身長の者は 高脂血症の合併率が高く、注意を要する。今後危除因子のスク リーニングに身長の因子も考虑する必要がある。 


\section{2 日本人における $\beta_{3}$ アドレナリン受容体Trp64Arg変異 一八丈貫コホートにおける検时一 \\ 東京大学第三内科、日本医科大学第二内科*

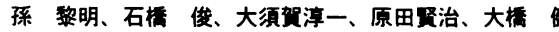 福生吉裕*、山田借博、矢崎航雄}

[目的] $\beta_{3}$ アドレナリン受容体は白色およひ褐色脂肪組驖に おける脂肪分解やエネルギー産生調節に重要な役割をはたし ている。近年、ヒトのTrp64Arg変暴か報告され、肥満や、 NIDDMの早期発症との閂连が指摘されてきた。今回、八丈島

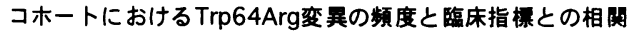

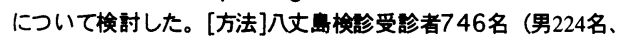
女522名、平均年令52藏）を対象とし、制限蟀羔BstN1によ るPCR法RFLPにより多形部断した。統計はANOVAおよびカ イ二乗模定を用いた。[結果]Trp64Arg変異の木モは51名 (6.7\%)、ヘテロは246名(33\%)、野生型は449名(60\%)で あり、これらの频度に男女差は認められなかった。全体で解 析した場合、BMI、血清脂要、高血压、虚血性心疾急、糖尿病 の有病率との間には有意な相閔は認められなかった。しかし、 血海総蛋白は、Trp64Arg変暴木モが野生型に比して 有意

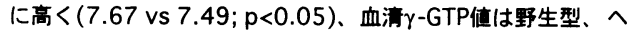
テロ、木モの順に有意に增加傾向を示した(22.9 vs 28.1 vs $35.4 ; \mathrm{p}<0.001)$ 。[結諭]今回対象とした八丈島コホートに おいては、 $\beta_{3}$ アドレナリン受容体Trp64Arg変異の肥満及び糖 尿病有病率への閶与は証明されなかった。しかし、血海総蛋

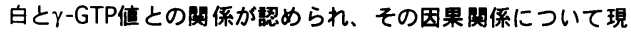
在検討中である。

\section{3 シンバスタチン長期投与時の心電図変化}

宮崎愛和病院 内科 $\cdot$ 成人病研究室, *同検査科, **滋賀医大第 1 内科, ***京都予防医学センター

齊藤曻, 土居芳枝, 青海仁, 中島一郎, 村田比, 安永孝高, 中山清兒*, 神谷美紀”, 佐山睛海 $* *$, 神奈木俊子***

[目的］シンバスタチン投与による、血清脂質および心電図所見 による心筋虚血への影響を検討した。

[方法］以下の高 TC 血症の患者に、シンバスタチン $5 \mathrm{mg}$ を夕食 後に投与し、早朝空腹時の血清脂質および、安静時と運動負荷時 (Master double)の心電図を測定記録した。

1）シンバスタチン服用のみの患者 11 例（男 6, 女 $5 ; 58.5 \pm 11.4$ 歳(mean $\pm S D) ;$ 観察期間 $22.5 \pm 10.1$ months)

2）糖尿病を合併し経口血糖降下剂を服用する患者 9 例（男 5 ,

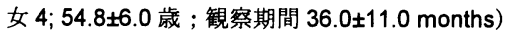

3）冠不全を合併し冠拡張剂を服用する患者 5 例（男 3，女 2; $62.4 \pm 9.2$ 歳; 観察期間 $15.6 \pm 5.9$ months)

[成績] 全症例においてシンバスタチン投与前後の比較で、PQ と $\mathrm{S}_{\mathrm{V}_{1}}+\mathrm{R}_{\mathrm{v} 5}$ はほぼ不変であった。シンバスタチン投与のみの患 者では、ST の低下は観察されず、また、運動負荷時に境界反応 であった 2 例が正常化した。しかし、糖尿病合併例においては、 3 例が ST の悪化（ST 低下の出現あるいはその増強）とともに WNLから冠不全へ移行した。この 3 例は FBS が $200 \mathrm{mg} / \mathrm{dl}$ に近 く血糖コントロールが不良であった。また、冠不全合併例のうち 2 例でST の悪化、 2 例で ST の正常化(ST 低下の消失)が見られた。 [結語] シンバスタチン単独投与の高 TC 血症患者においては、 シンバスタチンにより運動負荷テストの境界反応が正常化した 2 症例が見られた。また、糖尿病合併例においては、3 例において 冠不全が発生したが、いずれも血糖コントロール不良例であうた。
174 シンバスタチン長期投与による生化学検査值への影響 宮崎愛和病院 内科・成人病研究室, “同検査科, “滋賀医大第 1 内科, **ネ京都予防医学センター 齊藤曻, 土居芳枝，青海仁，中島一郎，村田比，安永孝高，

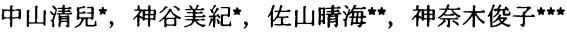

[目的] シンバスタチン長期投与時の生化学検査值の変動を調 查した。

[方法］シンバスタチン $5 \mathrm{mg}$ を夕食後投与し、 1 年以上経過 観察した 55 例（男 25 ,女 30、59.1 111.2 歳）について、空腹 時血清脂質, アポ蛋白, その他の臨床検査値について最長 4 年 の観察をおこなった。

[成績] シンバスタチン投与により治療前の TC 值, FBS 值に かかわりなく、TCは下表のように良好に維持された。また、 LDL-C, Apo-B も同様に低下した。しかし、GOT, GPT, rGPT, $A L P$, Serum $\mathrm{Cr}$, BUN, FBS, $\mathrm{HbA}_{1 \mathrm{c}}$, Urinary albumin, Urinary NAG，Serum BMG，1.5 AG 等には全期間を通して有 為な変化は見られなかった。

\begin{tabular}{|c|c|c|c|}
\hline & pre treatment & 2 year after & 4 year after \\
\hline All cases & $269.1 \pm 22.1$ & $208.6 \pm 23.2$ & $219.3 \pm 25.5$ \\
\hline$T C<260$ & $250.0 \pm 5.7$ & $198.8 \pm 23.1$ & $195.0 \pm 12.1$ \\
\hline $\mathrm{TC}^{3} 260$ & $281.4 \pm 19.7$ & $214.0 \pm 22.1$ & $211.5 \pm 19.1$ \\
\hline$F B S<140$ & $266.3 \pm 16.3$ & $209.0 \pm 23.9$ & $216.0 \pm 14.1$ \\
\hline $\mathrm{FBS}^{3} 140$ & $275.4 \pm 33.6$ & $207.6 \pm 24.4$ & $208.0 \pm 14.8$ \\
\hline
\end{tabular}

[結語］シンバスタチン $5 \mathrm{mg}$ の夕食後投与により、長期にわ たり血清脂質を安定してコントロール出来る事が示された。

175 低 HDL-コレステロール血症のシンバスタチン

\section{広島鉄道病院内科、JT医薬紷合研究所} 高田耕基、浦田泰生

低HDL-コレステロール血症の継続的治療として、薬物療法は 必要であるが、クロフィブラート系薬鼡とともに HMG-CoA還元 蟀阻害剂も可能性がある。われわれは平成7年度日本動腺硬化 学会冬期大会において、シンバスタチンが低 HDL-コレステロー ル血症において HDL2-Cを上昇させる効果を有することを報告し た。今回高コレステロール血症 (絵コレステロール $>220 \mathrm{mg} / \mathrm{dl}$ )の 34 症例 (HDL-C $\leqq 40.0 \mathrm{mg} / \mathrm{dl}$ の 17 例と HDL- C $\geqq 40.1 \mathrm{mg} / \mathrm{dl}$ の 17 例) にシンバスタチンを 5 およ゙ $10 \mathrm{mg} / \mathrm{day}$ 投与し、その渄度依存性変 化の有無とその機序について検即した。方法: 外来通院中の 34 例 (糖尿病非合併例で女性は閉経後、II a 型 20例、II b 型 14例、平均 年令 53 才、男/女: 20/14)に対してシンバスタチン $5 \mathrm{mg}$ または $10 \mathrm{mg} /$ 日をそれぞれ 8 週間以上投与して、その投与前、 $5 \mathrm{mg}$ 後、お よび $10 \mathrm{mg}$ 後のリポ蛋白分画脂贫 (醉来法、超透心法)、血清およ びHDL 分画のアポ蛋白(SRID法)、ポストヘバリンリバーぜ活性 (Krauss の変法)、LCAT活性 (長㥓一赤沼法)、CETP蛋白量 (ELIZA 法)および活性 (Tall の方法) の変動について検即した。 結果 : 高脂血症表現型の差によらず、総コレステロール、LDL-C、 アポBは低下し、HDL-C, HDL2-C、アポA-Iは上昇したが、 HDL-C、アポA-I を除いて筧度依存性变化が琶められた。LCAT 活性は低下したが、浱度依存性変化は認められなかった。他の脂

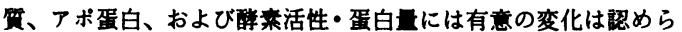
れなかった。以上の変化のうち、HDL-C, $\mathrm{HDL}_{2}-\mathrm{C}$ の変化は低 HDL-C群で著明であった。結詥 : 低 HDLーコレステロール血症の 治㫫にシンバスタチンは有効て、アポA-I 含有 HDL粒子の增加 が示唆されたが、HDL2-Cそのものの上昇機序は不明であった。 


\section{6 新しい陰イオン交換樹脂M C I - 1 96 とプラ バスタチンの併用効果}

金沢大学医学部第二内科、MCI-196北陸地区研究会 小泉順二、稲津明広、梶波康二、馬㴻 宏

[目的]MCI-196はコレスチラミンより強力な新しい陰イ オン交換樹脂であり、プラバスタチン $(\mathrm{Pr})$ との併用効果 を、へテロ接合体性家族性高コレステロール血症 $(\mathrm{FH})$ と 冠動脈疾患を有する高コレステロール血症 (CHD) で検討 した。[方法] FH (12例)にはPr (20mg、朝夕食後分2)を投与 L4週よりMCI (3g、朝夕食前分2)を16週まで併用した。 CHD (8例)にはPrを $10 \mathrm{mg}$ (夕食後) 投与し、以後FH と同様に 行った。[結果] TC (平均士SE) はPr 単独投与後、FH群で 363 $\pm 21 \mathrm{mg} / \mathrm{dl}$ より $294 \pm 19 \mathrm{mg} / \mathrm{dl}$ (18.4 $43.6 \%) 、 C H D$ 群で $270 \pm$ 14 より $231 \pm 11(13.7 \pm 4.68)$ 一低下した。MCI併用後のTC 值と $\operatorname{Pr}$ 単独後よりの低下率は、FH群では254 $212 、 12.4 \pm$

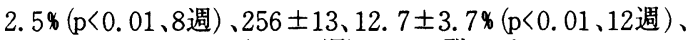
$255 \pm 12,9.1 \pm 4.4 \%$ (ns、16週)で、CHD群では207士12、12.7

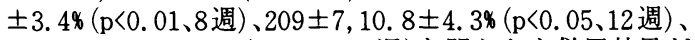
$201 \pm 9 、 16.4 \pm 2.4 \%(\mathrm{p}<0.01 、 16$ 週 $)$ と明らかな併用効果が 認められた。MCI併用投与後のLDL-CのPr 単独後よりの低

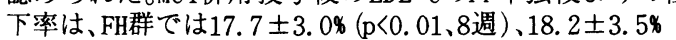
( $<<0.01 、 12$ 週)、14.2 24.88 ( $\mathrm{p}<0.05 、 16$ 週) で、CHD群では $20.7 \pm 4.8 \%(\mathrm{p}<0.01 、 8$ 週)、19.3 $\pm 5.2 \%(\mathrm{p}<0.01 、 12$ 週)、 $26.9 \pm 4.3 \%$ ( $\mathrm{p}<0.01 、 16$ 週) と有意な併用効果が認められ た。HDL-Cは両群で有意に增加したが、有意な併用効果は 認められなかった。[結語]MCI-196はFHおよびCHD患者に おいて、Prとの併用効果が認められた。従って、HMG-COA還 元䣼素阻害剂単独で効果不十分な場合、MCI-196とこれら の薬剂との併用が有用である。

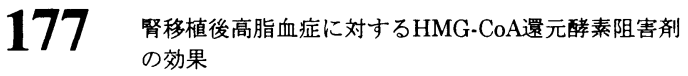 \\ 大阪大学泌尿器科高原史郎、市丸直呞、小角幸人、王晶釘 羽鳥基明、奥山明彦 \\ 井上病院泌尿器科亀岡 博 同内科 井上隆}

【目的】臟器移植後の免疫抑制療法により発生する高脂血症およ びその治療については国内での報告は少なく、統一された治療指 針もまだない。今回、堅移植後高脂血症に対するHMG-CoA還元 酵素阻害片の効果を検討するとともに、拒絶反応発現の一因と考

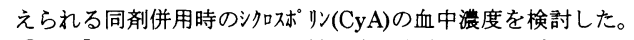
【方法】外来フォロ一の堅移植後高脂血症44例を対象として、食 事療法後にHMG-CoA還元酵素阻害郕であるプラベス外ン(P)とジバ 夘チン(S)を投与しそれらの効果を比較検討した。PからSに切り換 える際のwash-out期間は全例1力月以上とした。血清総コレス吅・ (TC), トリグリ七价 (TG), HDL-Cを測定し、LDL-CはFriedewald 式より算出した。その他に体重、堅・肝機能検査值を測定した。 $\mathrm{CyA}$ 血中㗳度は、単独投与時と $\mathrm{P} 10 \mathrm{mg}$ 併用時、S $5 \mathrm{mg}$ 併用時を 比較検討した。群間比較は分散分析後の多重比較で行った。

【結果】 P治療期間は $12 \pm 7$ 力月、S治療期間は $7 \pm 2$ 力月であった。 治療前とそれぞれの治療期間終了時の分散分析では、 TC, TG およびLDL-C值に有意差が認められた。TC, LDL-C值においては P投与に比してS投与が有意な低下を示し、TG值はS投与によって 治療前から有意に低下した。CyA血中涱度はP $10 \mathrm{mg}$ 併用時がや や高かったが統計上の有意差は認められず、本対象例において拒 絶反応はみられなかった。

【結論】本圾験はPとSの直接比較をしているものではないが、堅 移植後に合併する高脂血症の治療にはシタバス仸かがより適している と考えられた。

\section{8 無症侯性動脈硬化の危陷因子の解析}

大阪大学医学部第一内科、*大阪証券揵康管理センター 森悟、児玉峰男、内海恭子、辻野高史、荒井克已、堀本秀子* 山崎義光

【目的】近年、頝動脈 Bモード超音波検查法による動脈硬化定量 評価法が確立され、非侵襲的で絽り返し行えることから日常臨床 の場でその有用性が示されている。今回我々は䅡動脈超音波検查 を検診に導入し、無症状の青中年層の一般社会人の動脈硬化の定 量評価を試みた。

【対象·方法】 $26 \sim 59$ 歳の会社員 (平均年齢 $45.6 \pm 9.8$ 藏、男性 134 名、女性 32 名) を対象に定期検診時に既報のごとく超音波検 查を行ない、内膜中膜複合体 (以下 IMT) を測定した。統計学的 解析は One-way Annova で行い、重回㷌分析で無症状の一般社会 人の動脈硬化進展に対する危険因子を検索した。

【結果】正常者 (以下 N/C)72 名、高血圧 (以下 $\mathrm{HT}$ ) 8 名、高脂血症 (以下 HL) 58 名、高血圧、高脂血症合併 (以下 $\mathrm{HT}+\mathrm{HL}$ ) 18 名、 OGTT 境界型 (以下 IGT) 5 名、糖尿病 (以下 DM) 5 例で IMT は各々 0.88 $\pm 0.2 、 0.91 \pm 0.15 、 0.93 \pm 0.23 、 1.12 \pm 0.33 * 、 1.14 \pm 0.06^{*} 、$ $1.28 \pm 0.3 * \mathrm{~mm}(*$ : $\mathrm{p}<0.05)$ で、血圧、脂質、糖代謝異常などの危険 因子の集積に伴いIMT が肥厚する結果を得た。動脈硬化進展に 対する危険因子を抽出するため重回帰分析を行うと、年齢、総コ、 ステロール HDL-コレステロールのF值がそれぞれ 56.3、8.16、3.72 と独立 した危険因子として抽出された。【結論】無症候の一般社会人に 対する頙動脈超音波検診において血圧、脂質、糖代謝異常などの 危険因子の集積に伴い動脈硬化が進展する可能性を示唆した。し たがって、無症候の一般社会人に対する䅡動脈超音波検診による 動脈硬化定量評価の有用性とその必要性を示唆した。

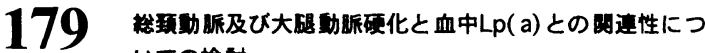 \\ いての模时 \\ 北院 \\ 吉村 竹田究祐
}

[目的] 功㖇破化意起性及ひ血栓形成性作用を持つとされる

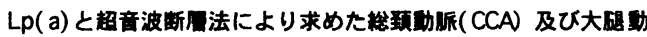

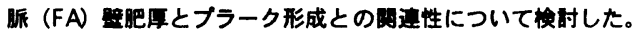

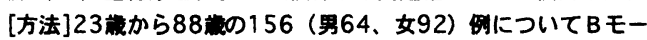
ド・エコー法にてCCA分技部10 mm近位部及び

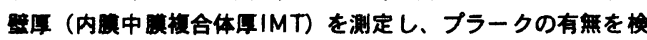
村した。IMTは左右の平均䛧として求めた。[結果] $L p(a)$ は CAでは $r=0.194 、 p<0.02 、$ FAでは $r=0.187, p<0.03$ でMTと有意の相网を示した。FAにブラークを有する群の $\mathrm{Lp}$ (a) は $29 \pm 26 \mathrm{mg} / \mathrm{d}$ (平均 $\pm \mathrm{SD}$ ) で有しない群 $(20 \pm$ $19 \mathrm{mg} / \mathrm{d})$ より塯加していた $(\mathrm{p}<0.02)$ 。年代別に㛟封す

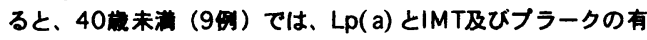

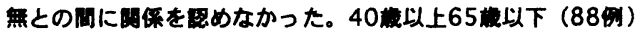
では、 $L p(a)$ はCCAのIMTと $r=0.263 、 p<0.02$ て相閏があ

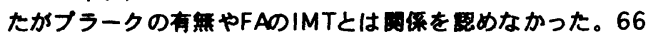
就以上 (59例) では、LP(a)とCCAのIMT及ひブラークの有無

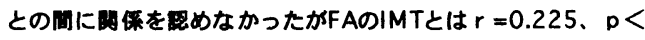
0.1 で相閴向を示した。FAにブラークを有する群のLp(a)は $35 \pm 31 \mathrm{mg} / \mathrm{d}$ で有しない群 $(14 \pm 6 \mathrm{mg} / \mathrm{d})$ より壦加してい

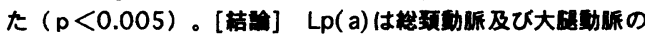

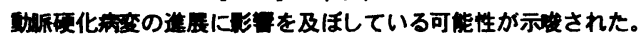




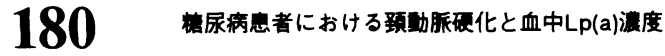

広里大学第二内科 山本真樹、山下城司、江草玄士、山木戸道郎

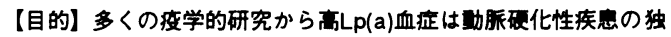
立した危険因子であることが指揞されているが、槽尿病息者にお いては末だー定の見解が得られていない。我々は搳尿病腎者にお

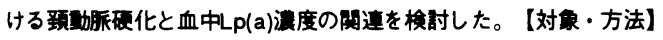
インスリン非依存型糖尿病息者 117 名（平均年令 58 才、

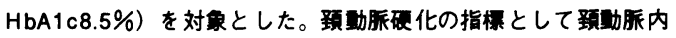

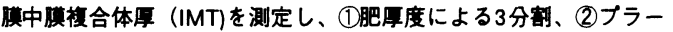
クの個数（0個、1個、2個以上）によろ3分割により、各群におけ

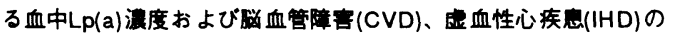
合併率について比模时した。【結果】(1) IMT值 0.65 $0.98 \mathrm{~mm}(\mathrm{n}=38)$ 、IMT值 $0.99 \sim 1.23 \mathrm{~mm}(\mathrm{n}=41)$ 、IMT值 $1.24 \sim$ $2.17 \mathrm{~mm}(\mathrm{n}=38)$ に分けると、各群における血中Lp $(a)$ 浱度は各々 $20.0 \pm 2.3 \mathrm{mg} / \mathrm{dl} 、 24.7 \pm 3.3 \mathrm{mg} / \mathrm{dl} 、 39.8 \pm 4.3 \mathrm{mg} / \mathrm{dl}$ と、 IMT塔加に伴い有意に上年していた。(2)プラークなし群 $(n=59) の$ $\mathrm{Lp}(\mathrm{a})$ 濃度は18.4 $\pm 2.5 \mathrm{mg} / \mathrm{dl} 、 1$ 個群 $(\mathrm{n}=24) 25.8 \pm 2.5 \mathrm{mg} / \mathrm{dl} 、 2$ 個以上群 $(\mathrm{n}=34) 38.7 \pm 5.1 \mathrm{mg} / \mathrm{dl}$ と目線的に满加しており、3群间 で有意差を䀔めた。(3)CVD合併群ではIMT值、Lp(a)湿度ともに非 合併群に比し有意に高值であった。IHD合併の有無による模封で は合併群の方がいずれも高值であったが、有意差は略めなかった。 またブラーク個数の塔加に伴いCVD、IHDの合併率は有意に上年

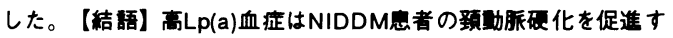
ると考えられた。さらに高L p(a)血症は福尿病性大血管障言進展と 阔連がある可能性も示㖫された。

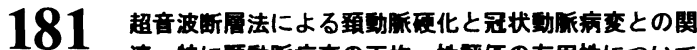

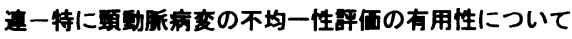
順天堂大学循環器内科

須郷亜紀子、中島滋夫、和田明珠、蔵田健、木下真弓

澤野眞人、佐藤裕之、山口洋

【目的】頝動脈内膜中膜複合壁厚 (IMT) は全身の動脈硬化症の指 標として用いられているが、その計測值には主に測定点の最大值 や平均值が用いられ動脈硬化病変の不均一性については考慮され てこなかった。そこで今回、複数点の測定值のばらつき度を新た な評価法として加え冠状動脈病変の有無との関連を検郡した。

【対象と方法】対象は当科に入院し頝動脈超音波と冠状動脈造影 検査を同時期に施行した 180 例(男性 133 例、年齢 $60.9 \pm 10.1$ 歳) で、その内訳は虚血性心疾患 142 例、動脈疾患 14 例、弁膜症そ の他 24 例である。左右頸動脈各 8 力所の IMT の平均值(MEAN)を 測定し、さらに不均一性の指標として各測定値間の分散 (VAR)を 算出した。主要冠状動脈 $50 \%$ 狭窄以上を有意病変とした。

【結果】顠動脈超音波が明瞭に記録できたのは 172/182 例(95\%) で、このうち MEAN が $1 \mathrm{~mm}$ 以上(MEAN+群) と末満(MEAN-群)の 2 群 各々で冠状動脈病変を有する率は $75 / 80$ 例 (94\%) と 70/92 例 (76\%) でMEAN+群が有意に大きかった $(\mathrm{P}<0.01)$ 。MEAN+群の VAR は 0.217 \pm 0.260 で、VAR がこの平均值より高い(VAR+群) 26 例は全例に冠 状動脈病変を認めたのに対してより低い(VAR-群) 54 例中 5 例では 冠状動脈病変を認めなかった。さらに MEAN-群でも VAR+群はVAR群に対し冠状動脈病変を有する率は各々 $25 / 30$ 例 (83\%)、45/62 例 (73\%) と VAR+群で高い傾向にあった。

【結論】IMT の平均値のみの評価に比べて、分散を加味すること によって冠状動脈硬化病変との一致率を向上させることができた。 超音波断層法による IMT を全身の動脈硬化症、特に冠状動脈病変 の有無を予測する指標として評価する場合には、その厚さの測定 のみならず不均一性も考慮すべきである。
182 頸動脈超音波断層法における病変の評価方法

一特に冠動脈病変の検出に関して一

相模原協同病院循環器科 - 日本大学医学部第二内科*

杉村秀三荒木康史 杤原敏彦 鈴木研欽 鑇田智彦 長澤正樹 高橋由美子* 藤岡考之* 上松瀬勝男*

【目的】頸動脈超音波断層法(CAUS)は非侵䇾的かつ簡便に動脈 硬化の程度を評価できる検査法で、冠動脈疾患の補助粀断として も有用である。しかし、その評価法はまちまちで、どの方法がよ り適切であるかは不明である。今回我々は、内中膜厚(IMT) と plaque の二点から、より適切な評価法について検誩した。【方法】 対象は虚血性心疾患が疑われ冠動脈造影検査(CAG)及び CAUS を施行した 41 名である。CAUS は $7.5 \mathrm{MHz}$ の探触子を用いて、 両側頭蓋外頸動脈を評価し、左右総頸動脈の plaque を除いた IMT、plaque の個数、最大の plaque の厚さについて検討した。 CAG は Judkins 法で施行し、有意狭窄は AHA 分類で $75 \%$ 以上 とした。【結果】冠動脈病変のない 18 例と狭窄を有する 23 例と に分類して評洒すると、左右の内中膜厈の平均值は前者が $0.78 \pm$ $0.25 \mathrm{~mm}$ 、後者が $0.95 \pm 0.40 \mathrm{~mm}$ であり、また左右いずれか肥厚 の程度が強い部位では、 $0.85 \pm 0.31 \mathrm{~mm} 、 0.99 \pm 0.38 \mathrm{~mm}$ でとも に有意差を認めず、両者を区別することは困難であった。一方、 両者で plaque の数、最大厚の対比を行ったが、前者では $56 \%$ で plaque を珰めなかったのに対し後者では $96 \%$ plaque を認め、 その数、黾さよりも plaque が存在するか否かがより重要である ことが判明した。【結埨】CAUS で冠動脈疾患の存在を予測する 場合、IMT よりも plaque の存在の有無がより適切である。

183 頚動腺超音波断層法によるシンバスタチン投与前後に おける動脤硬化病変の倸価

自衙隊中央病院内科 0 、防衙医科大学校第 3 内科、女子栄養 大学 第 2 生理 ${ }^{*}$ : 青木 晃 ${ }^{\circ}$ 、角誠二郎、永瀬晃正、村上 健彦、赤津 拓彦、山本通子、工藤一彦* 、永田直一

[目的］我々は、シンバスタチンの投与前後で䫫動脈の内膜 中膜複合体 (INC) やプラーク像がどのように変化するかを顆 動脈超音波断層法を用い梌討した。[方法］対象は45才から 65才までの高脂血症患者10例（男性 4 名、女性 6 名）。シン バスタチン $5 \mathrm{mg} / \mathrm{day}$ を 1 年間投与し、その前後で血清脂質、 IXC、プラーク像などを剆定、観察した。［結果］投与前後 で血清脂質は絵コレステロール、LDL コレステロールは有意 に低下したが、中性脂肪、HDL コレステロールでは有意な低 下はみられなかった。IVT は前值1.145士0.203mm が 1 年後に は1.035士0.176mm と有意に退縮していた。うち2 例において は畐ax-IVT が1.8m から1.5m 1.2m的 へと退縮がみられた。［結詥］血清脂質を低下させる ことによる動脤硬化病変進展抑制が様々なコントロール・ス タデイーで報告されているが、今回の我々の研究では非侵悲 的榆查法である頚動脈超音波断層法を用いて、シンバスタチ ンでの奻果を確認しえた。個々の症例においてそのIM を経 時的に钼察することで動㟲硬化病変の進展、退縮を評価しえ たが、その方法論等は今後さらに検討する必要がある。 
184 血管内皮增殖因子（VEGF）の発現に及はすglucose 欠乏の影需

名古屋大学老年科佐竹昭介、暮谷雅文、三浦久幸、浅井传亘、 ミゲル・ラモス、井口昭久

大塚製薬株式会社細胞工学研究所 村口正宏、大本安一

【目的】血管内皮增殖因子 (以下VEGF) は、内皮細胞に対する特 異的增殖因子であり血管内皮細胞の維持、侧副血行路形成等の血 管新生に重要な役割を果たしている。今回我々は、VEGF 発現に及 はすglucose 久乏の影零について検討した。【方法】1)ヒト単球細 胞系のU-937細胞を6mM D-glucose 含有培養液（対照群）と1 1mM Dglucose 含有培盖液（低血耤群）に一定時間基霖し、そのVEGF mRNA 発現量をノーザンフロット法により、又培養上清中のVEGF

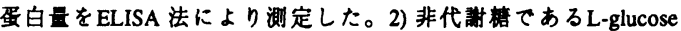
$5 \mathrm{mM}$ と $1 \mathrm{mM} \mathrm{D}$-glucose 混合培美淮（L-glucose 群）に一定時間瞵露 しVEGF mRNA 発現量をノーザンフロット法により検討した。3) 一定時間低血糖で培盖した後、その培養液上清を回収しD-glucose を6mMに補正した。この補正培養湤を別のU-937 細胞に一定時間 懪露（補正群）しVEGF mRNAをノーザンフロット法により梌討 した。【桔果】1)細胞を低血楉に曝露した時のVEGF mRNA の発 現は18 時間以後て明らかな增強が見られ、低血糖による細胞障害 は48時間後ても詪められなかった。又、VEGF 蛋白澌は18 時間、 48 時間ともに低血糖群て有意 $(\mathrm{p}<0.05)$ に增加していた。2) Lglucose 群は対照群に比べVEGF mRNA 発現量は增強していた。3) 補正群は同時間暴露した低血楉群よりもVEGF mRNA 発現は娍少 しており対照群と同程度であった。【桔詥】VEGF mRNA 及び VEGF 蛋白䜤の発現はD-glucose 欠乏により增強しており、VEGF

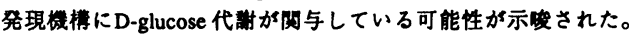

185

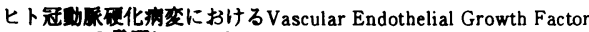
(VEGF)の発现について

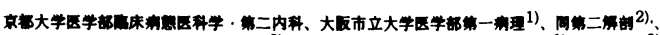

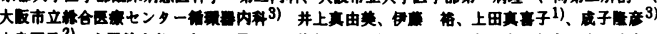

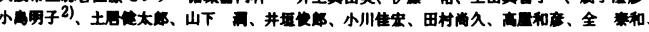

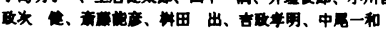

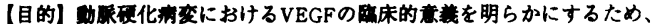
ヒト冠地展硕化洞変部におけるVEGFの発現を検㣙し更に培盖血管細胞に おけるVEGFmRNA発現阙節も合わせ検村した。【方法】部㭘15症例より

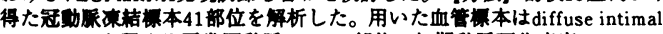

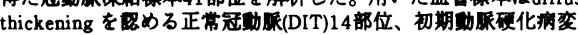
(hypercellular lesion; HC)7部位、㑺行野脱现化病棸のうちlipid-rich core

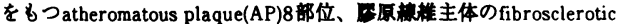
plaque(FSP)7部位、及び血栓器资化・再㻋通を伴う total occlusion(TO)5部

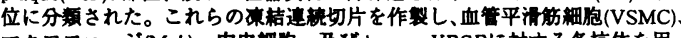
マクロファージ(M ф)、内皮䋖胞、及び human VEGFに対する各抗体を用

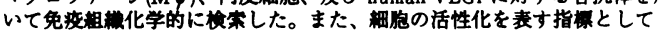

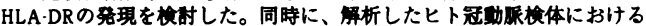

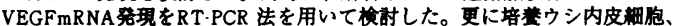
ラットVSMCを用いて、VEGF造伝子発現洞篃についてNorthern blotting法

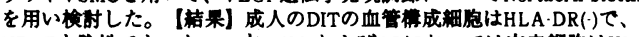
VEGF も登性てあった。一方、HC およびAPにおいては内皮細炮はHLA. DR(+)と佸性型を示しこれらの内皮細胞はVEGF性でった。また、病 変部に存在するM や、合成型ないし中間型フェノタイブのVSMCにおい

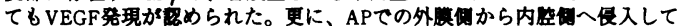
いる vasa vasorumの内皮細胞 $(H L A \cdot D R(+))$ やTOの血栓器而化部位におけ

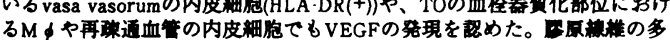
いFSPにおいてはVEGF(-)でったたRT-PCR 法を用いたVEGF运伝子発現

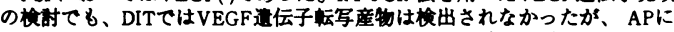
おいてはVEGFmRNA発现を䁌めた。更に、培賞ウシ内皮細胞、ラット VSMCても VEGFmRNA(3.7Kb)の発現を琶め、血消剌溸 (10\%ウシ胎仔血

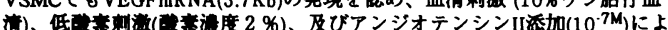

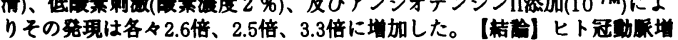

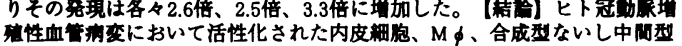
フェノタイプのVSMCにVEGFの発現が叞められることがはしめて明らか

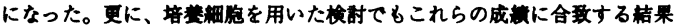

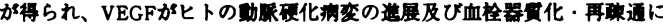
おいて貣な役割を果たしていることが示睃された。

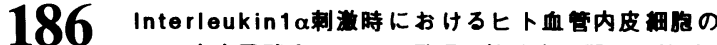

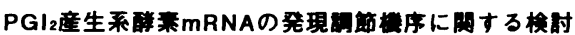

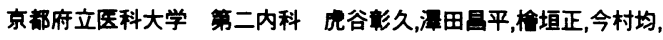

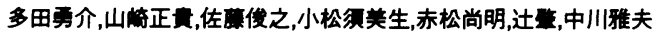

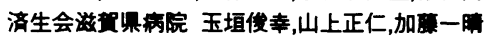

【目的】血管病变の発症進展には内皮細胞が百要な役寁を果たす

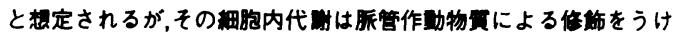

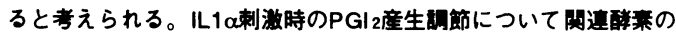

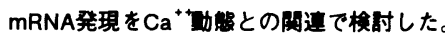

【方法】 HUVECを用い，[Ca $\left.{ }^{+*}\right]$ lはfura-2/AM，PGl およびPP3は

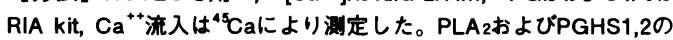
mRNA発現量はcompetitive PCRにより定贯湖定した。

【结果】非刺湤時におけるHUVECのPGI2産生はincubation開始 冝後から满加し15分後にplateauに造した。U1a刺湤によりPGI 産生は15分後では变化を思めなかったが，180分後においては萝加 した。IL1a刺激により[Ca" なかった。IL1 $\alpha$ 刺湤により添加15分後ではPGHS1のmRNA発現量 は不変であったが, PLA2, PGHS2発現は满加し, 180分後ではPLA2 およびPGHS1，2の発現ともに满加した。同一反応系におけるPLA 2

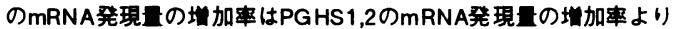
大であった。

【結涻】IL1 $\alpha$ 刺激により添加15分後において，既にPLA2および

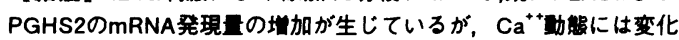
を罗めずPG12産生は不变であったと考えられた。しかし添加180

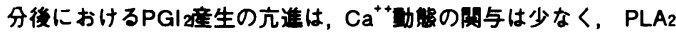
およびPGHS1,2のmRNA発現塔加を介した倳序により生している 可能性が考えられた。

\section{7 アデノウイルスを用いたCNP 遺伝子導入によるラット血 管内皮剥離モデルにおける内膜肥厚の抑制作用}

千葉大学医学部第 2 内科、九州大学医学部循程器内科*、 サントリー（株）生物医学研究所 ** 春野明弘、上野 光*、森琦信尋、古谷真優美 ${ }^{* *}$ 、雍康 康

[目的] C型ナトリウム利尿ペプチド（CNP）は静脈内持続注入によ り内膜肥厚を抑制することを報告した。今回CNP発現アデノウ イルスベクター (AdCACNP) を用い血管壁にCNP 遣伝子を導入し、 局所でのCNPの産生を増加させることによる内膜肥厚の抑制作用を 検討した。[方法] 1.ラット培養平滑筋細胞を用い、AdCACNP、ア

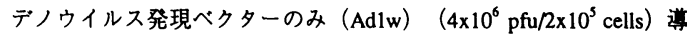
入後培盖上清中のCNPおよびcyclicGMP量をRIA法で測定した。2.ラッ 卜の左総䫫動脈のballooning直後に同部位の血管壁にAdCACNP (3.5 $\left.\times 10^{8} \mathrm{pfu}\right) 、 A d 1 w\left(1.9 \times 10^{8}\right)$ およびマーカーとしてLacZ発現ア

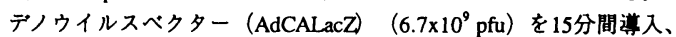
4日ないし2週後に左総䫱動脈を摘出し組織切片を作成、X-Gal染色、 CNP染色、内膜肥厚度（内膜／中膜面積比、I/M ratio）の算出を行っ た。[結果] 1.AdCACNPの導入により、ラットSMCの培養上清中に

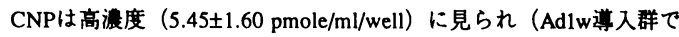
は検出限界以下）、cyclic GMP量も顕著に上昇（20.90土0.42 $\mathrm{pmole} / \mathrm{ml} / \mathrm{well}$ ) した（Adlw導入群では0.78 $\pm 0.02 ） 。 2 . A d C A L a c Z$ 䍝 入後4日目の摘出左絵顠動脈の中膜において、LacZ串伝子の血管壁 での発現を確認できた。また、AdCACNP導入後中膜にCNPの発現 が見られた。3.AdCACNP導入群（I/M ratio：0.41士0.32）ではAdlw 導入群（I/M ratio：1.20土0.16）に対し、導入2週後に66\%の顥著な 内膜肥厚抑制作用を示した。[結論] CNP遗伝子の血管壁局所への革 入により、影著な血管内膜肥厚の抑制作用が見られた。 
188 PDGF刺激によるfocal adhesion kinase活性化に果たす phosphatidylinositol 3-kinaseの役割

千葉大学医学部第二内科 齊藤雄司 森聖二郎 横手幸太郎 神崎哲人 森崎信尋 齋藤 康

【目的】 Focal adhesion kinase(FAK)は細胞のfocal adhesionに局在す る非受容体型チロシンキナーゼである。最近、FAKのノックアウ トマウスが作製され、細胞遊走におけるFAKの重要性が明らかと なった。PDGFはin vivoでFAKを活性化する増殖因子の一つである が、我々は以前PDGF受容体下流のシグナル伝達分子である phosphatidylinositol 3-kinase(PI3K)が、PDGFによる細胞遊走に必須 であることを報告した。今回我々は、PDGFを介するFAKの活性化 においてPI3Kが果たす役割について検討した。

【方法】FAKの活性化は、ヒト㨊帯静脈由来平滑笳細胞(SMC)や ヒトPDGF $\beta$ 受容体を発現させたブタ大動脈内皮細胞(PAE)を PDGF-BBで刺激した後、抗FAK抗体で免疫沈降を行い、次いで抗 リン酸化チロシン抗体でイムノブロットを行って評価した。PI3K 活性の阻害には、薬物と人工的変異型受容体発現細胞を利用した。 【結果】 PI3Kの特異的阻害薬である wortmanninは、SMCでPDGF 刺激によるFAK活性化を完全に抑制した。さらに、野生型ヒト PDGF $\beta$ 受容体を発現させたPAEではPDGF刺激によるFAK活性化 が見られたが、PI3Kとの結合部位を持たないY740/751F受容体発 現PAEでは、PDGF刺激後のFAKの活性化は認められなかった。一 方、FAKの活性化に重要であると推測されたSrcとの結合部位を持 たないY579F受容体発現PAEでは、PDGF刺激でFAKが活性化され た。

【結語】PDGF受容体下流のFAK活性化過程に、PI3Kが関与して いることが強く示唆された。また、受容体に結合するSrcは、FAK 活性化過程に必須ではないことも明らかになった。

189 PDGF $\alpha$ 受容体特異的細胞内シグナル伝達へのアプロ 一千

千葉大学医学部第二内科

横手幸太郎、齋藤雄司、森聖二郎、齋藤康

【目的】血管平滑筋細胞に対する強力な増殖・遊走因子であ るPDGFは、動脈硬化病変の形成に重要な役割を果たすと考え られている。PDGFは細胞表面の $\alpha$ および $\beta$ 受容体に結合して その作用を発現する。これまでの通念と異なり、PDGF $\alpha$ 受容 体の活性化は細胞遊走や血小板凝集に抑制的に働くことが最 近報告された。PDGF $\alpha$ 受容体に特異的なシグナル伝達機構の 解明は、動脈硬化発症機構の解明、更には新しい治療法の確 立にもつながると考え、我々は $\alpha$ 受容体特異的シグナル伝達 物質の同定を試みた。【方法】PDGF $\alpha$ 受容体に特異的な自己 リン酸化部位である 762 番目のチロシン残基とその周辺の アミノ酸配列を模したリン酸化合成ペプチドを用い、これに 結合する細胞内蛋白を精製した。さらに変異型PDGF受容体を 遗伝子導入した培養細胞を用い、この精製蛋白とPDGF受容体 の相互作用について検討した。【結果】アフィニティー精製 により、チロシンリン酸化依存的に合成ペプチドと結合する $27 、 38$ および $40 \mathrm{kDa}$ 蛋白が得られた。部分アミノ酸配 列の解析により、これらの蛋白はニワトリ発癌ウイルスの遺 伝子産物に類似したCrkファミリーの蛋白群であることが判明 した。Crk蛋白はin vivoで自己リン酸化したPDGF $\alpha$ 受容体と 結合するが、 $\beta$ 受容体とは結合しなかった。変異型 $\alpha$ 受容体 を用いた検討により、Crk蛋白は $\alpha$ 受容体細胞内ドメインに存 在する 762 番目のチロシン残基と高い特異性をもって結合 することが確認された。【結論】我々は、PDGF $\alpha$ 受容体と特 異的に結合する細胞内シグナル伝達物質を世界で初めて同定 した。Crk下流シグナルの解析は、PDGF $\alpha$ 受容体に特異的な シグナル伝達機構の解明とその制御を可能にすると思われる。
190 血中free apo(a) \% と血清 $\mathrm{Lp}(\mathrm{a})$ 漕度との関連について 一血清Lp(a)漕度調節因子としてのアルブ ミン存在一 防衛医科大学校第一内科 中岛 辟、西脇正人、澤田正二朗、繁 英樹、

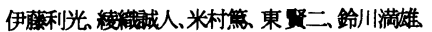
富安幸志 宮帛恵美子、石川俊次、中村治雄

【目的】近年、 Lp(a) assemblyは肝細胞外で apo(a) とDLの結合に より形成されると報告されているが 血中のapo(a)の湌度、存在様式、及 びp(a)assemblyに及ぼす血中ファクターについては明らかでない。 そこで血中free apo(a)䈨度及びその\%(free apo(a)/total apo(a)× 100 ; free apo(a)\%)を測定し、また、Lp(a) assemblyに及ぼす血 中ファクターについても検討した。【方法】In vivo；255人の患 者(60.1士12.4歳)を対象とし、沈殿法にてfree apo(a)を測定した。

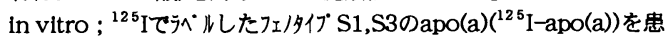

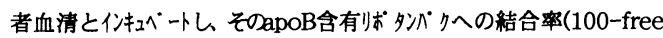
\%)を测定し、さらに、健常者LDL ( n LDL) と ${ }^{125} \mathrm{I}-\mathrm{apo}(\mathrm{a})$ の結合率 に及ぼす患者LPDSの影语も検討した。結果】血中free apo(a)濃

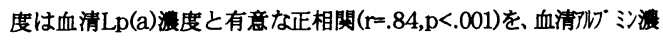
度とは有意な負の相関( $\mathrm{r}=-.31, \mathrm{p}<.0001)$ を示したが、 LDL-C,apoB㳘

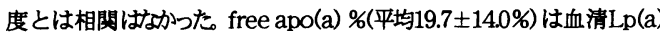
湫度と有意な負の相関 $(r=-.52, \mathrm{p}<.001)$ を示したが、他の脂貫とは 相関はなかった。 ${ }^{125} \mathrm{I}-\mathrm{apo}(\mathrm{a})$ の忠者apoB含有师 多パクとの結合 率は血清 $\mathrm{Lp}(\mathrm{a})$ 涺度と有意な正相関 $(\mathrm{r}=.39, \mathrm{p}=.002)$ が認められ、患 者LPDS存在下でのnLDLへの結合率も、血清 $L p(a)$ 湍度と有意な正 相閶 $(r=.32, p=0.01)$ を示した。またこの結合は牛アルブミ添加により 浱度依存性に阻害された。【哧論】血清free apo(a) 湌度及びその

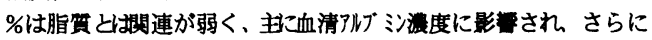
血中free apo(a)\%がLp(a) assemblyに影すると考えられた。

191

Lipoprotein(a)の血小板集笓、粘着能に及ほす影要 東海大学医学部 循塄器内科

布施川雄一、多田博己、小第利明、椎名豊、

玉地寛光、半田俊之介

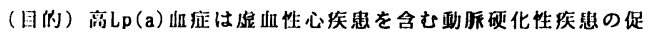
進凶子とされている。その償成蛋白である apo(a)はplasminogenと

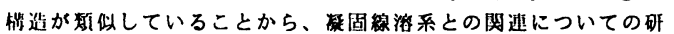

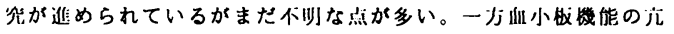

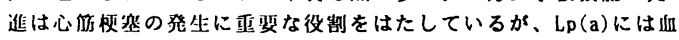

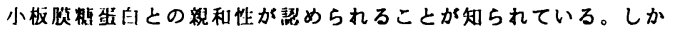

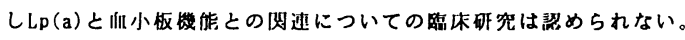

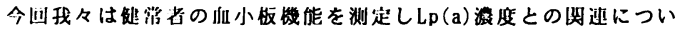
て领到した。(方法) 刘象は非唤䙳能常男性91名とした。血小板

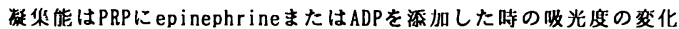

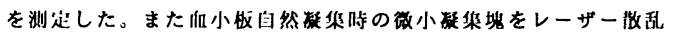
光を朋いた少治で饮出した。Lp(a)はELISA法で测定した。（結果） $\mathrm{Lp}(\mathrm{a})>12 \mathrm{mg} / \mathrm{d} 1$ の対象群（HLP、 $\mathrm{n}=46$ ) と $\mathrm{Lp}(\mathrm{a})<12 \mathrm{mg} / \mathrm{d} 1$ の対象群 （LLP、 $n=45$ ) との間に、年略、平均血压、肥满度、血精值、血清 脂留、PT、APTT、Fibrinogenおよひ全血中血小板数に有意差は訆 められなかった。师小板自然集時の微小集地はHLPがLLPより も付意に高值を示した $(\mathrm{p}<0,01)$ 。微小保集地の $\log$ 值と $\log (\operatorname{Lp}(\mathrm{a}))$ は行意な正相闯を示した $(r=0,321 、 p<0,01)$ 。epinephrineおよひ

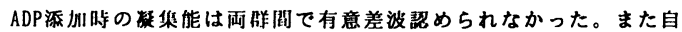
然集時の微小集地はPG-D2、PG-E1、PG-12、EDTAおよひ抗GP IIb·IIIa抗体により抑制された。(考察)高Lp(a) 血症者の動脈硬 化の発生と非展には吹小板機能の六進が成連していることが示唆 された。またその予防には血消しp(a)を低下させる楽制意外に、血

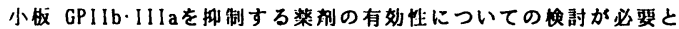
尧えられた。 
若年者動脈内膜の $\mathrm{Lp}(\mathrm{a})$ の内弾性板沈着一年齢との関俰

日本大学医学部第二病理、Chicago 大学病理 ${ }^{*}$ 芳賀孝之、楠美嘉晃、絹川典子、Sheikh Aleemuzzaman,竹川 義則、大荷 澄江、高木 洋史、桜井 勇、R.W. Wissler*

[目的] 若年者動脈において Lp(a)の沈着が内弹性板（IEL）に高率 に生じることを、第25回日本動脈硬化学会総会で発表した。今回 は我々は IEL への Lp(a)沈着と加跉との関連について検索した。 [方法]米国の PDAY study 検体で血清 Lp(a)濃度 $20 \mathrm{mg} / \mathrm{dl}$ 以上を 示す 32 例（15 34 才の男性、 5 才毎に 4 群に分ける）の腹部大動 脈標本（10\%ホルマリン固定）を対象とした。羊ポリクローナル抗 apo(a)抗体 (Immuno 社)を用いて免疫組織化学的に Lp(a)沈着部を 染色した。IEL への Lp(a)沈着を明らかにするために連続切片で弾 性線維染色を施行し、Lp(a)の IEL への沈着範囲をIEL の全長に対 する相対的な長さとして検討した。

[結果(表)および考察] 1. Lp(a)の IEL 沈着の出現頻度は各年齢 群に有意の差が無かった。2. Lp(a)沈着がみられるIELの相対的 な長さは加齢と共に増加する傾向があった。3. Lp(a)はIELに進行 性に沈着する脂質である可能性が示唆された。

\begin{tabular}{|c|c|c|c|c|c|}
\hline & \multicolumn{4}{|c|}{ IEL への Lp(a)沈着 / IEL の長さ } \\
\hline 年齢 (才) & 例数 & $(-)$ & $(<1 / 4)$ & $(1 / 4-1 / 2)$ & $(1 / 2<)$ \\
\hline $15-19$ & 8 & 2 & 2 & 4 & 0 \\
\hline $20-24$ & 8 & 2 & 4 & 0 & 2 \\
\hline $25-29$ & 8 & 2 & 0 & 4 & 2 \\
\hline $30-34$ & 8 & 1 & 0 & 5 & 2 \\
\hline
\end{tabular}

\section{3 動脈内膜沉おける変性 $\operatorname{Lp}(\mathrm{a})$ の存在}

日本大学第二病理 !、株)シノテスト2、自治医大大宮医療センター3、 Chicago 大学病理 ${ }^{4}$ 楠美 嘉晃 '、新橋真理 ${ }^{1}$ 長田宏已 山田 晋吾 $^{2} 、$ 久保 ${\text { 信彦、櫻林 郁之介 }{ }^{3} 、 \text { R.W.Wissler }{ }^{4} \text { 、櫻井勇 }}^{1}$

[目的］動脈内膜に沈着した Lp(a)には酸化等による変性が加わ っている可能性がある。若年者大動脈における変性 $L p(a)$ の存在 の有無について検討した。

[方法］米国の PDAY study 検体(15～34 才の男性)を用い、抗 apo(a)抗体 (Immuno 社)による免疫染色で Lp(a)沈着が認められ た45例の腹部大動脈標本を対象とした。161E2 抗体（井上らが 第28回動脈硬化学会総会にて発表）による免疫染色を施行し、 変性 $\mathrm{apo}(\mathrm{a})$ の存在を検索した。

[結果および考察］45例中41例(91\%)で内弾性板および肥厚 内膜染部の細胞外成分などを中心に変性 $\mathrm{Lp}(\mathrm{a})$ の局在が認めら れた。Lp(a)の動脈硬化促進機序に変性 $\mathrm{Lp}(\mathrm{a})$ の関与の可能性 を考える必要がある。
194

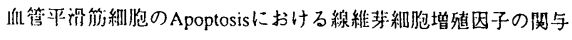

久留米大学医学部第 2 病理

加藤誠也 宮本哲哉 安川秀雄 森松 稔

University of Pennsylvania Jonathan C. Fox, Jason R. Shanley

[目的] Vascular remodelingの過程では、一部の血管平滑筋細 炮(SMC)のApoptosisが報告されている。今回、我々はSMCが Antisense(AS)塩基性線維芽細胞增殖因子(bFGF)の導入によって Apoptosisを呈する系を作成し、外因性bFGFのApoptosis発現に対 する影響を検討した。[万法] 培養ラットSMCにAS-bFGF RNA を発現するAdenovirus Vectorを感染してApoptosisを誘導した。こ の際、Luciferase 導入Vectorを対照として使用し、総細胞数及び Propidium Iodide染色後核崩壊を呈するApoptotic cell また細胞周期の検討のため5-Bromo-2'-deoxyuridine(BrdU)の取り込 みを钼察した。bFGFは、単独ないし bisindolylmaleimide(bIM) =Protein Kinase $\mathrm{C}$ inhibitor $を し く く$ wortmannin =Phosphatidyl inositol-3-Kinase inhibitorと伴に培地へ添加した。［䊅果］外因性 bFGFによるSMCの增殖はbIM添加ないし高浱度Phorbol esterによ り浩度依存性に抑制され、wortmannin添加に影響されなかった。 Apoptotic cellの割合は非感染群及びLuciferase virus投与群では $0.5 \%$ 以下であり、AS-bFGF投与群は $30+8 \%$ であった。外因性bFGF添 加はAS-bFGF投与によるApoptotic cell の割合を $21 \pm 2 \%$ と減少させ たが、bIMを同時に添加した場合、33+9\%とAS投与のみの群と同 程度の值を示した。bIMないしwortmannin単独ではApoptotic cellの 割合は変化しなかった。 AS-bFGF投与群では、BrdU陽性と同時 にApoptosisを示す細胞数が增加し、外因性bFGF添加により減少 した。[結 論］内因性bFGFの抑制はSMCのApoptosisを誘道し、 細胞周期上、S期への不適切な移行が関与している可能性があ る。外因性FGFは、增殖やApoptosisの制御に傎き、一部はPKCの 活性化を介した細胞内伝達譏搆を介していると予想される。
195

ラット預動脈Balloon Injury後の新生内膜肥厚における アポトーシスの誘導と細胞死シグナルFasの発現誘導 大阪大学医学部第四内科 中橋 媇、福尾恵介、蒋 冰冰、廣谷 淳、畑 茂樹、 須原敏充、清水真澄、森本茂人、荻原俊男

[目的］今回PTCA後の再狭窄の発症に血管構成細胞の細胞死 がどのように関与するのかを明らかにする目的で、ラット預動脈 のBalloon Injuryモテルを用い、細胞死シグナルであるFasの発現と 誘導型一酸化空素合成酻素（iNOS）の発現との関係を検討した。 [方法] Wistarラットの総預動脈を麻酔下で2F Fogaty catheterにて 賃害後、病理標本を作製し内膜肥厚を対側をコントロールとして 評価した。また、連綍切片を用いてFasの発現を免度組織染色にて、 またアポトーシスをTUNEL法にて観察した。iNOSのmRNAの発現 は傷害後、頝動脈よりTotal RNAを抽出し、RT-PCR法にて検討し た。さらに培養細胞系を用いてFasの発現をフローサイトメトリー を用いて検討した。[結果] ラット預動脈伤害10日後の預動脈で は新生内膜は著明に肥厚し、その新生内膜内に多数のTUNEL陽性 細胞が認められた（約36\%）。また抗Fas抗体を用いた免疫組織染 色では新生内膜内にFas陽性細胞が多数認められた。しかもFas 陽 性細胞はTUNEL非陽性の細胞においても認められた。一方、 iNOS mRNAの発現は隻害後早期に認められ、傷害後12時間をピー クにその後は徐々に発現が低下した。さらに、細胞培養系におい てNOドナーであるSodium nitroprusside (SNP) は平滑筋細胞にお けるFasの発現をup regulateした。[総括] ラットBalloon injuryモ テルにおいて、iNOSの誘導を介したFasの発現が新生内膜におけ る細胞死を誘導し、傷害血管の組織修復機構として関与している 可能性がある。従ってPTCA後の再狭窟の発症メカニズムに関し、 Fasを介した細胞死の機構の観点からも検討する必要がある。 
196 ラットballoon injury modelにおけるアボトーシスと Bcl-2 familyの発現

東京大学医学部第三内科南野微, 栗原裕基, 前村浩二, 森田啓行, 大橋芳雄, 新藤隆行, 栗原由紀子, 矢䗁峩雄

【目的】血簕平清筋細胞のアボトーシスはその增殖とともに動脈 硬化形成週程に重要な役割をもつと考えられている。また、 Bc1-2 familyは样 ななタイフのアポトーシスに閶与しているこ とが辄告されている。そこで回我々は、平清筋細胞のアポトー ンスに对ナるBcl-2 familyの闪与を㽗へるためラットballoon in jury modelを用いて検刢した。【方法】ラットballoon in jury modelにおける平渭筋細胞の增殖とアボトーシスを検討 するため、侮害後 3 日、7 日、1 4 日目のサンフルを用い、抗 PCNA抗体による免疫組織染色とTUNEL法を行った。Bc1-2 familyの遭伝子発現については同槏のサンフルを用い、 Northernblot法にて解析した。【䊅果】TUNEL ${ }^{+}$細胞は侮害後 3 日目においては中膜平滑筋の内腔側第一層に散見されるのみで あった。7日目になると形成された肥厚内膜の平滑筋細胞のうち 約半数がTUNEL ${ }^{+}$細胞であったが、14 日目にはその数は減少 していた。PCNA ${ }^{+}$細胞もその細胞数や局在性にっいてはほ同様 の所見を示した。PCNA／TUNEL二重染色では肥厚内膜の内腔㑡 にTUNEL ${ }^{+}$PCNA $^{+}$細胞を認めた。Bcl-2,Bcl-x(antiapoptotic gene)のmRNAレベルは3 日目より滅少傾向を認めた のに対し、Bax,Bak(pro-apoptotic gene)のmRNAレベルは 3 日目より增加し、Bax,Bak/Bc12,Bcl-x 比は7 日目にビーク (約 6 倍)を示した。【䊅論】ラットballoon injury modelにおける 平滑筋細胞のアポトーシスは細胞增殖と密接な関俰をもち、その 過程にはBc1-2 familyのmRNAレベルの変化が関与している可 能性が示唆された。

\section{PTCA後再独宏における細胞遊走促進因子の重要性}

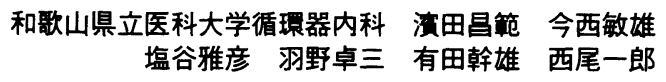

【目的】患者血清中に存在する細胞增殖又は遊走促進因 子がPTCA後の再狭窄に関連するか否かを検討するため 患者血清を培䍜ヒト大動脈平滑筋細胞に添加し細胞の增 殖及び遊走能を測定した。

【方法】PTCA 施行患者連続110例を対照にPTCA当日 早朝に採血した血清をDMEM 培地に $10 \%$ 添加し、細胞 增殖能をneutral redを用いた比色法で、一方遊走能を chemotaxis chamberを用いた染色法で半定量した。 【結果】連続110例のPTCA 中42例(38.2\%)に再狭窄を 認めた。細胞增殖能は再狭窄群と非再狭窄群で有意差が なかった。細胞遊走能は再狭窄群で有意に高值を示した $(p<0.001)$ 。他に再狭窄群では冠動脈硬化指数,Lp(a)， FBSが有意に高値, apoAが有意に低值であった。 【結論】PTCA後の再狭窄はLP(a)高值や低HDL血症等の 他に、血清中に含まれる細胞遊走能促進因子が重要な役 割をしていると考えられる。

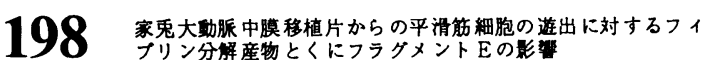

名古屋大学・老年科学 内藤通孝、野村秀樹、井口昭久

University of Aberdeen $\quad$ W.D. Thompson, E. B. Smith

【目的】心血管系疾患の危険因子に関する疫学研究は虚血性心疾 患、媨血栓、下肢閉塞性動脈硬化症の危険因子として、血浆フィ プリノケン（Fbg）濰度に血策コレステロールと同等以上の重 要性を明らかにした。本研究では動脈硬化童形成および血栓器質 化の主役、血管平滑筋細胞(SMC) の中膜移植片からの遊出に対す るフィブリン分解産物 (FDP) の影签を検討した。【方法】家鬼胸 部大功脈中膜移植片からのSMC 造出の定量はMcMurray らの方法 に準し、1 $\mathrm{mm}^{2} に$ 細切して96-well plate に解異し、DMEM +20\%FBS にて培荃した。細胞が遊出した移植片の\%および遊出距噰を計湘 した。SMC は抗SMC $a$-actin 抗体によって同定した。FDPは精製 Fbg からトロンビン添加により作成したフィフリン（Fbn）をフ ラスミンで48h 処理することにより得た。【耛果】FDPは家鬼大 動脈中朕移植片からのSMC 迶出（形質転換、遊走、增殖を含む） の潜時を短縮し、遊出距部を增加させることにより促進、刺激し た。トロンヒンはSMCの遊出に影霓しなかった。FDPのこの作 用はその中の主要なものの一つである fragment $\mathrm{E}$ に対する特異抗 体によって抑制されたが、fragment Dに対する抗体では抑制され なかった。また、これらの抗体自身には作用はなかった。さら に、精製されたFbn fragment E は移植片からのSMCの遊出を刺激 した。一方、フラスミンによる Fbg 分解産物やFbg 由来fragment $\mathrm{E}$ にはこの作用はなく、Fbg からトロンヒンンよってフィフリリノ゚ フチドが切断されることが必須であった。【䊅論】 FDP（とくに fragment Eを含分分解産物）が動脈壁中膜 SMC の造走、増殖、そ して、おそらくは形筫転换に影慗することによって㲜脈硬化の発 生、進展に重要な役割を果たしている可能性が示唆される。

血管平滑筋細胞の增殖に及はすトロンボモジュリン （TM）の影雷

福井医科大学第 3 内科、昭和薬科大学公衆衛生学・ 東田元、策田耕治、河野光志、鈴木仁弥、岡田映子、玉井利孝、 石井秀美・、中井継彦

【目的】動脈硬化巣は、增殖した血管平滑筋細胞と泡沫細胞から 成る。我々は、助脈硬化病変部位において、SMCおよび泡沫細 胞に、T Mが発現していることを報告した。最近 石井らは、 EGF-1ike domain を含んだTM peptide (r-TME1-6) が、3T3 細胞などに対して増殖活性を示すことを報告した。今回、助脈硬 化巣形成の一端を解明する目的で、T M の血管平滑筋細胞の增殖 に及はす効果について検討した。

【方法】ラット大動脈中膜より、平滑筋細胞を explant 法にて単 雄し、10\%FBS-DMEMを用いて培䓹した（4-8代）。48時間 無血清培地で処愳後、r.TME1.6を加えて28時間培盖を行った。 DNA合成能は [ $\left.{ }^{3} \mathrm{H}\right]$ - thymidine の細胞内への取り込みを指標と した。また r-TME1-6添加後の細胞数を、経時的にカウントした。 【哧果】 $\left[{ }^{3} \mathrm{H}\right]$-thymidine の取り込みは、r-TME1-6の港度依 存性に増加し、 $50 \mathrm{ng} / \mathrm{m} 1 て ゙$ 約 3.4 倍であった。細胞数は、 $1 \%$ FBS·DMEMで培蒀したものと比䡈して、r·TME1-6を加えた场合 は約 1.9 倍に增加した (14日後)。EGFとr·TME1.6 の存在下 では、 [ $\left.{ }^{3} \mathrm{H}\right]$-thymidineの取り込みにおいて 相加作用が認めら れたが、insulinとの相加作用は見られなかった。

【桔論】 T M は、港度依存性にSMCの增殖を刺激し、また EGF との共存下では、增殖活性は促進された。以上より、T Mの動脤 硬化亲形成への成与が推察された。 


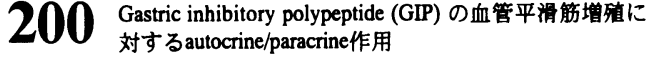
大阪大学医学部第四内科

廣谷 潡, 森本茂人, 山口博司, 大熊浩, 西部影, 福尾恵介, 荻原俊男.

【目的】GIPは食事依存性に腈管より分泌され，インスリン分 泌を促進するベプチドホルモンである.インスリンが野脈硬化促 進作用を持つことはよく知られているが、その刺激物質である GIPの心血管系への直接作用は知られていない，我々は，培善血 管平滑筋細胞(VSMC)およびラット頊動脈バルン内皮障害モテル を用いてその作用を検时した。

【方法】1.[3 HThymidine取り込みおよびCell countにより GIPの VSMC增殖作用を梌討した. 2.VSMCにおけるGIPレセブターの存 在をRT-PCR 法にて検封した．3.VSMCによるGIPの産生を RT-PCR, 免疫細胞染色にて梌封した. 4.ラット頙㲜脈バルン 害モデルを用いて新生内膜におけるGIPの存在を免疫組織染色に て検封した.

【結果】GIPは $10^{-8} \mathrm{M}$ 以上の湌度において㩐度依存性およひ時間 依存性にVSMCの增殖を促進した，GIPレセブターは膦碳，周と 同様にVSMCに発現を認めた. VSMCにおいて十二指渴之同栐に GIPの発現が確認された．さらに，免疫細胞染色でもVSMCは阳 性に架色され，VSMCにおけるGIPの産生が示唆された。预娌脈 内皮障害モテルでは，新生内膜の平滑筋細胞に一致してGP倡性 細胞が存在した. 一方，正常の中腆平消筋は染色されなかった

【結语) GIPは血管平滑觔絧胞增殖作用を示し，その作用は分 泌型平海筋細胞から産生されるGIPによるautocrine作用による可能 性が示唆された。

\section{1 高糖瀑度による血管平滑筋細胞增殖抑制作用 機構一PKC アイソザイムの関与}

大阪市立大学第 2 内科 ${ }^{1}$,横浜市立大学第 2 生化学 ${ }^{2}$ 山川健次郎 ${ }^{1}$, 細井雅之 ${ }^{1}$, 福本真也 ${ }^{1}$, 西沢良記 ${ }^{1}$, 大野茂男 ${ }^{2}$, 森井浩世

【目的】高糖瀑度刺激時の血管平滑筋細胞の増殖及び PKC isozymeの発現との関係について検討した。【方法, 結果】ラッ血管平滑筋細胞由来のA7r5においては、25-250 $\mathrm{mM}$ のD-Glucose 高糖浱度刺激 6 時間により糖瀑度依存性 にPKC deltaのmRNAレべの増加を認めた。一方PKC alpha の発現に差を認めなかった。PDGF24時間刺激後の ${ }^{3} \mathrm{H}-$ thymidine uptakeは糖峘度依存性に抑制された。PKC アイ ソザイムの役割を検討するために、PKC delta及びalfaの遗 伝子を導入し、stableにoverexpressionする細胞株(Dt)及び (At)を確立した。Diは、A7r5およびvectorのみを導入させ た細胞株(Vt) と比へ、PKC deltaの発現はPDBu binding と Northern blotting 法で1.5ー2倍増加しており、Westem blotting法で2ー3倍の増加を認めた。他のisozyme やalpha actinの発現には差を認めなかった。 ${ }^{3} \mathrm{H}$-thymidine uptakeは DではA7r5とVtに比べ約20\%に低下しており，一方Atでは 特に差を認めなかった。さらにDにPKCdelta dominant negative mutant の低下はVtのレベルにまで回復した。 flow cytometryによ ろ検討ではDはS 期への侵入が逑延していた。c-fos,c-jun や cdk 2,cdk 4,cyclin D2,D3の発現はA7r5、Vt、D で差を認 めなかった。細胞周期蛋白の cyclin Dl のmRNAレ゙ネはDで はVt,A7r5に比べ約50\%低下していた。これに伴い、cyclin E, cyclin Aの発現も24時間遅延していた。【結論】高榶港 度における血管平滑筋細胞の増殖にはPKCアイソザイム の関与が認められ、PKC deltaはcyclin D1 の発現を抑制す ることにより平滑筋細胞の增殖を抑制すると考えられた。
202 高血圧自然発症ラット(SHR) 由来血管平滑筋 細胞(VSMC)におけるPDGF-A長鎖の発現調節 日本大学医学部第二内科 岸岡博文、福田 具、中山智祥、佐藤 力、渡辺吉康、 相馬正義、泉 洋一、上松瀨勝男

【目的】PDGF-A鎖mRNAはalternative splicingにより第6エク ソンを含む長鎖と含まない短鎖が生じる。前回、本学会で我々 はSHRのVSMCでPDGF-A長鎖の発現が充進し、第6エクソン に対するアンチセンスオリゴがSHRのVSMCの過剩增殖を抑制 する事を報告した。今回、SHRのVSMCでPDGF-A長鎖の発現 調節を検討したので報告する。

【方法】10週令雄性SHR及びWistar-Kyotoラット(WKY)の胸 部大動脈よりVSMCを分離し継代培養した。SHR及びWKYの VSMCに血清、アンジオテンシンII (Ang II)、TGFßを作用させ、 PDGF-A鎖mRNAの発現は第6エクソンを挟むプライマーを用 いRT-PCR法にて测定した。

【結果】RT·PCRで297bpと366bpにそれぞれPDGF-A短鎖及 び長鎖mRNAが認められ、両者はSHRのVSMCで充進していた。 PDGF-A長鎖mRNAの発現は10\%仔牛血清存在下で特ににSHR のVSMCで充進していた。1 $10^{-5} \mathrm{M}$ Ang II及び $10^{-5} \mathrm{M}$ TGFßは SHRのVSMCで特にPDGF-A長鎖mRNAの発現を六進した。

【結論】增殖の速いSHR由来VSMCではPDGF-A長鎖mRNAの 発現は亢進し、Ang IIおよびTGFßにより刺激されSHR由来 VSMCの過剩增殖に関与している可能性が示唆された。

\section{Wortmannin (Wort)のラット培養大動脈平滑筋細胞} (SMC)の增殖シクナルに及はす影管

神戸大学医学部第一内科, 保健学科* 高橋明広, 谷口隆弘 河崎悟, 小田明彦, 吉田裕司, 清水洋志, 石川雄一*, 横山光宏

【目的】ホスフォチジルイノシトール3-キナーゼ (PI3K)の 強力な阻害菜であるWortmannin (Wort)のPDGF刺激時の細胞 内情報伝達に及ほす影䇾を調べた。

【方法】PI3K活性、GTP結合型Ras活性はSMCをWortて5分 間前処置後、PDGF-BBで2分間刺激して得られたœll lysaes を抗ホスホチロシン抗体(4G10)あるいは扰Ras モノクローナ ル抗体(Y13-259)で免疫沈降し、薄層クロマトクラフィーで 展開し测定した。MAPキナーゼ(MAPK)及びS6キナーゼ (p70S6K)の活性はPDGFて 10分間刺激して得られた lysatesをそれぞれ特異的にリン酸化される合成ペプチドを基 筫に用いて評価した。c-fos m-RNAの発現はPDGFにて30分 刺激後、ノーザンブロット法にて評価した。

【結果】Wort は港度依存性にPI3K活性、p7056K活性、GTP 結合型Ras及びMAPKを抑制し、50 nMのWortはこれら全て を100\%抑制した。c-fos m-RNAの発現は100 nMのWortにて約 50\%抑制された。

【結論】WortはPI3Kからp7056 Kへ至る経路のみならず、 RasからMAPKに至る経路も抑制していた。PI3KはRasの上 流でその活性を調節していることが示唆された。 
204 神経堤細胞から血管平滑筋細胞への分化および血管形成に おけるエンドセリン-1 - HAND経路の役割

東京大学医学部第三内科、 ${ }^{2}$ 同病理、 ${ }^{3}$ University of Texas

South western Medical Center 栗原由紀子 ${ }^{1}$ 、栗原裕基 ${ }^{1}$

Deepak Srivastava ${ }^{3} 、$ Eric N. Olson ${ }^{3} 、$ 小田秀明 $2^{2} 、$ 石川隆俊 $^{2} 、$ 矢崎義雄 ${ }^{1}$

【目的】最近我々はジーンターゲティングよりエンドセリンー1 （ET-1）椺マウスを树立し、血管平滑箅への分化能を有する神 経堤細胞の発生分化にET-1 か関与していることを明らかにした。 本研究では、このマウスの心血管奇形と遺伝子発現の解析からET1 の発生学的役割を检討し、ET-1の下流にある造伝子の同定を試 みた。【方法】1) 䧟伝子欠損マウス表現型の解析：形態は実体

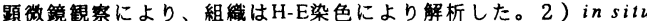
hybridazation : digoxigeninでラベルしたantisense RNAにより hybridizationを行い、alkaline phosphatase標識抗digoxigenin 抗体で処理後、発色反応を行った。【結果】ET-1欠損マウスは、 頭䅡部の穓弓由来組緎・器官の致死的形態異常とともに、大動服 弓およひ起始部の形成異常・心公中隔欠損を示した。その頻度 ・ 程度は母体への抗ET-1モノクローナル抗体やET-A受容体拮抗莱 BQ123の投与により增加した。心形成初期では、驺弓動脈形成異 常が認められた。胎生9日のwhole mount in situ hybridazation では、ET-1 mRNAの発現は鰓弓の上皮細胞・心流出路の心内膜細 胞・大血管の内皮細胞に最も著明に認められた。ET受容体逞伝子 の発現は神経堤細胞に一致して認められた。同し時期のET-1 欠損 マウスでは、袖経堤・心䑏に強く発現しているbHLH型核転写因子 dHAND, eHANDの発現が著明に低下していた。神経堤細胞に発現 するホメオホッックス运伝子Msx1，2の発現は遗伝子次損マウスお よび野生型で差かなかった。【結論】 ET-1は、上皮-間葉相互作用 の介在因子として、HAND遗伝子を含めた細胞系特異的な道伝子 転写系を活性化することにより、頭部/心綳神経堤細胞から血管平 滑筋細胞などへの分化・增殖を促進している可能性が考えられた。

205 大動脈平滑筋細胞における proteinの産生

高知医科大学第二内科 公文義雄

Boston Univ. Medical center, Sipe, J.D., Schreiber, B.M. Dartmouth Medical School, Brinckerhoff, C.E.

[目的] Serum amyloid A protein(apoSAA)は急性期蛋白の 一つであり，ウサギでは主に肝で合成されるapoSAA1,2 と肝外組織で産生されるapoSAA3があることが報告さ れた。今回，我々はウサギ大動脈平滑筋細胞(SMC)を用 いて，サイトカイン刺激によるapoSAAの産生について 検討した。[方法] 生後3日目のウサギより得られたSMC を継代培養し実験に用いた。apoSAAの発現及び産生は, 培養液中にIL-1及びIL-6を添加し, 経時的及び各種濃 度別に検討した。SAAmRNAの検出は, Northern Blot 法及びRT-PCR法を用い, apoSAAの培盖液への分泌は 免疫沈降法にて検討した。[結果] 無刺激下でもSMCは 微量のSAAmRNAの発現を認めた。IL-1の添加により この発現は増加し, これはSAA3の増加によるものであっ た。SAA3mRNAの発現は刺激後2時間から増加した。 この発現はIL·1 $0.01 \mathrm{ng} / \mathrm{ml}$ の低濃度から濃度依存的に 増加したが、IL-6刺激下では増加しなかった。これら のSAA3の発現は培養液中へ産生分泌されたapoSAAの 結果と一致した。[結論] 培養SMCに発現しているSAA mRNAは，IL-1刺激により著明に増加し，これらは主 にSAA3であった。A ApoSAAはSMCへのコレステロール の取り込み促進や，細胞外マトリックスの構築に関与 するMMPsの産生誘導に関与することより，䂾状硬化 形成に局所で関与している可能性がある。

\section{6}

血管平滑筋によるアクチビン-Aの産生

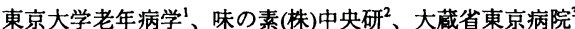

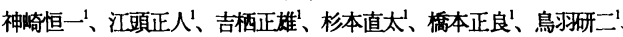
長野宏一朗、須藤紀子、江藤袞、折茂肇、大内尉義

【目的】アクチビン-AはTGF- $\beta$ スーパーファミリーに属し、TGF- $\beta$ 同様、細胞機能の調節に重要な勳きを有している。アクチビン-Aの 血管への作用としてこれまで、平滑筋増殖促進作用、内皮增殖抑制 作用が報告されており。また我々はアクチビン-Aがマクロファージ

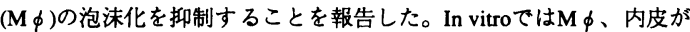
アクチビン-Aを産生することが示されている。今回我々は、さらに 血管平滑筋がアクチビン-Aを産生することをin vitroならびにin vivo で確認したので報告する。【方法】日本白色ウサギ胸部大動脈より 分噰培養した血管平滑筋細胞(RSMC)を用いて、(1) 培養上清中のア クチビン-Aの濃度をbioassay(赤芽球分化誘遒活性)により測定した。 (2) RSMCにおけるアクチビン-A mRNA(3a鎖)の発現をNorthern blot解 析により検討した。(3) ヒト剖検冠動脈標本を用いて、アクチビン-A の発現を免疫組織染色により検討した。また同連続切片を抗平滑筋 抗体(HHF35)、抗M $\phi$ 抗体(HAM56)を用いて染色し、アクチビン-Aの 局在を検討した。【結果】(1)RSMCの培養上清中に、アクチビン-A

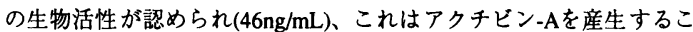
とが知られてるTHP-1M фの上清中蕽度 $(16 \mathrm{ng} / \mathrm{mL})$ より高值であった。 (2) RSMCにおいてアクチビン-A mRNAの発現が確認された。(3) ヒ 卜冠動脈において、アクチビン-A は新生内膜及び中膜に発現してお り、その分布は平滑筋の分布にほほ一致した(一部では $\mathrm{M} \phi$ の分布と も一致した)。【結論】RSMCを用いたin vitroでの検討、ヒト冠動脈 標本を用いたin vivoでの検討より、アクチビン-Aが血管平滑筋より 産生されることが明らかになった。

\section{7 柿状動脈硬化巢における Betacellulin およびその受容体の局在}

大阪大学医学部第二内科：田村 律、西田 誠、宮川潤一郎、 中田敦之、木原進士、山下静也、竹村 芳、松沢佑次 武田薬品工業：佐々田玲子

【目的・方法】 Betacellulin (BTC)は EGF family に属する新し く発見された增殖因子である。我々は BTC がヒト血管平滑筋細 胞に対して in vitroで增殖促進活性を示すこと、またと卜大動脈 において BTCが平滑筋細胞およびマクロファージの一部に局在 し、動脈硬化巣形成過程に関与していることを明らかにしてき た。最近、BTCが EGF receptor (EGF-R)のみならずこれ以外の 受容体を介して增殖促進活性を示すことが報告されている。す なわち、EGF family に属するEGF、TGF- $\alpha$ および HB-EGFは EGF-R(erbB-1)に結合するが、BTC は HB-EGFとは異なり EGF-R 以外に erbB-4にも直接結合して作用することが明らかと なっている。今回ヒト大動脈硬化病変の形成過程における BTC およびその受容体の役割を明らかにするため、BTC の局在とと もに EGF-R と erbB-4 の局在について免疫組織学的に検討した。 方法はヒ上剖検例で得た胸部大動脈組織をホルマリン固定後バ ラフィン切片を作成し、BTC は抗 BTC 抗体( rabbit polyclonal)、 EGF-R は抗EGF-R 抗体( mouse monoclonal) , erbB-4 は抗 erbB-4 抗体 (rabbit polyclonal) を用いた。【結果】1)大動脈において BTC 免疫活性は内膜の中膜側に強く、中膜平滑筋細胞の一部に も認めた。2)EGF-R と erbB-4 は免疫組織学的に BTC とほほ同 様の局在傾向を示し、その受容体の局在している細胞は平滑筋 練胞と考えられた。【結諭】 BTCは EGF-R と erbB-4を介して 大動脈平滑筋細胞の增殖を促進し、動脈硬化巣形成過程に重要 な役割を演じている可能性が示された。 
208 ヒト単球由来 macrophage $(\mathrm{M} \phi)$ およびヒト血管平滑肪細胞 (SMC)におけるC3 産生およびCR1の発现

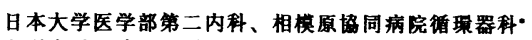

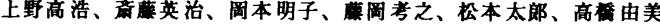

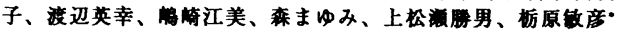

【目的】動后硬化病変における主要な細鹤であるM ゆおよびSMC の茂体成分C 3 産生および㭪体レセブターCR1の発現とそれに対す ろnative LDL(n-LDL)およびoxidative LDL(ox-LDL)の)を培

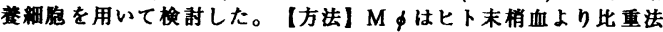

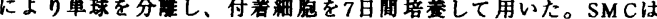
ヒト舞带動より explant法にて培盖し、第5代を用いた。LDLは 血清より超速心分法にて分棤した。ox・LDLはLDLを $10 \mu \mathrm{MCuSO}$ 含有Ham's F-10 mediumと $37^{\circ} \mathrm{C} て ゙ 15$ 時間incubate して作成した。各䋧鹤の培養液にn・LDLおよび $50 \mu \mathrm{M} / \mathrm{ml} 、 100 \mu \mathrm{M} / \mathrm{ml}$ の浱度て加元 24 時間刺消した。C $3 、 C R 1$ 発现は培菜液及びSDSにて海解した細息を、SDS·PAGEを行った 後、抗C 3 c抗体、抗CR 1抗体を用いてwestern blottingにて模村

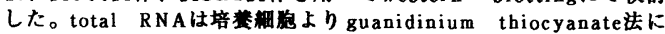
て精製し、random primer法にて逆転写反店を行いcDNAを作成 した。これをPCR法にて增幅し、2\% agarose gelにて泳動した。

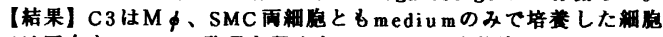

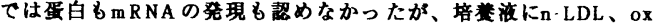
LDLを加えた群では廃現を裙めた。CR1はM めではmediumのみて

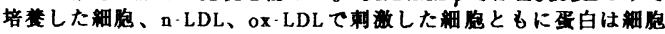

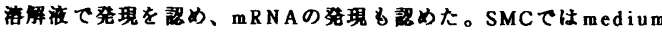

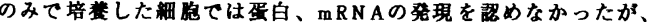

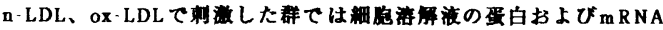

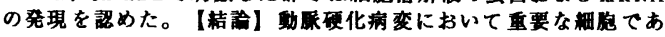

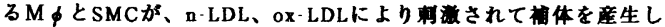
SMCではこれらのリボ蛋白により剌激されてCR1る登現すること

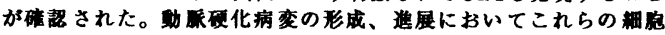
とリボ蛋白、㭪体系が関与している可能性が示された。

209

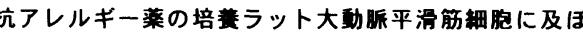
す影䈏〜ペミロラストとトラニラストの此较梌討〜

東邦大学佐倉病院内科

金井正仁，大沢秀文，野池博文，内孝，吉沼正鲁、略和仁，

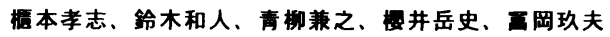
【目的】抗アレルギー菜は、眠满䎩胞や好酸球からの炎症性尔 ミカルメティエーター遊新抑制作用を有する。ここには梱胞内 カルシウム遊抑揦か閶与しており、これらがケロイトおよひ

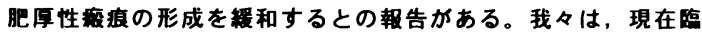
林的に再狭窄预に有用とされるぺミロラストとトラニラスト の血管平滑能細胞增殖およひ遊走抑制効果について检討した。

【方法】10\%ウシ胎仔血清(FCS) 存在下において、培费ラット 大動眽平滑筋细胞上清中にペミロラスト $\left(10^{-7}-10^{-4} \mathrm{M}\right)$ あるい はトラニラスト $\left(3 \times 10^{-5}-3 \times 10^{-4} \mathrm{M}\right)$ を添加し、一定時間後に梱 胞数を計泮した。さらに、同様に $1 \%$ FCS 存在下PDGF添加刺湤 での一定時間後の增殖抑制効果およひBoyden's chamber 法に基ずく遊走抑制効果を検即した。

【結果】增殖抑制効果; ペミロラストは10-6 Mから、トラニラ ストは $3 \times 10^{-5} \mathrm{M}$ から血管平漫筋梱胞增殖を用量依存性に抑制

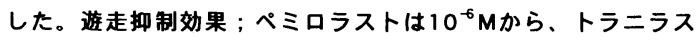
卜は3 $\times 10^{-5} \mathrm{M}$ から血管平滑筋細㴔增兔を用量依存性に抑制し た。

【結詥】ペミロラストとトラニラストは血管平滑能䎩胞の增殖 およひ遊走抑制作用を有した。ペミロラストとトラニラストの 比较では、ペミロラストの方か增埴能では䄱300倍、遊走能で は約30 100倍の力価を有することが碓琵された。

\section{0 デキサメサゾンは血管平滑筋細胞における石灰化を促 進しうる}

大阪市立大学医学部第二内科

森克仁、西沢良記、塩井 淳、城野修一、森井浩世

【目的】デキサメサゾンは、血管平滑筋細胞の増殖、遊走に 対して抑制的に作用することが知られている。また、balloon injury後の内膜肥厚を抑制することも報告されている。しかし 血管石灰化に対する作用は明らかにされていない。そこで、 血管平滑筋細胞によるin vitroでの石灰化実験系を用いて、デ キサメサゾンの血管石灰化に対する影響について検討した。 【方法および結果】ウシ大動脈由来血管平滑筋細胞 (bovine aortic smooth muscle cells : BSMC) を $15 \% \mathrm{FCS}$ と $10 \mathrm{mM}$ sodium pyruvateを含むDMEMにより confluentになるまで培養した。そ の後 $\beta$-glycero-phosphate ( $\beta$-GP)を添加し石灰化を誘導し、同 時にデキサメサゾン $\left(10^{-9}-10^{-6} \mathrm{M}\right)$ を添加した。デキサメサゾン $10^{-} \mathrm{M}$ 添加後の細胞層のCa含量を測定したところ、経時的に增 加し4日目ではコントロール群に比し321\%、6日目では411\% の増加を認めた。また、同様に石灰化誘導3日目にアルカリ フォスファターゼ(ALP)の活性測定をおこなったところ、コ ントロール群に比し、デキサメサゾン添加により用量依存的 にALP活性は上昇し、デキサメサゾン $10^{-6} \mathrm{M} て ゙$ 最大 $277 \%$ まで增 加した。これらのことより、デキサメサゾンは in vitroでの石 灰化実験系において、ALP活性を上昇させるとともに、細胞 層のCa含量を壃加させることが示唆された。

【結論】血管平滑筋細胞の石灰化に対し、デキサメサゾンは 促進的に作用する可能性が示唆された。

211 活性型ビタミンDは血管平滑筋細胞における石兏化 を促進する

大阪市立大学医学部第二内科

城野修一、西沢良記、塩井 淳、森 克仁、森井浩世

【目的】活性型ビタミンDをラットに大量投与すると動脈硬化が促 進するといわれているがその作用メカニズムについては明らかでは ない。in vitroでは、ラットの血管平滑笳細胞において、1,25( $\mathrm{OH})_{2}$ Vit $\mathrm{D}_{3}$ の受容体が存在しており、活性型ビタミンDは細胞增殖を抑 制するという報告がある。進展した動脈硬化病巣には血管石灰化が 認められ、この血管石灰化の進展に活性型ビタミンDが直接作用し ている可能性が示唆される。そこで血管平滑筋細胞における石灰化 に対して活性型ビタミンDがどのように作用するかをin vitro石灰化 実験系を用いて検討を行った。【方法㧍よび結果】ウシ大動脈由来 血管平滑筋細胞を $15 \%$ FCSを含むDMEMにより confluentになるまで 培窇した後及-glycerophosphateを添加し石灰化を誘導した。前回、我々 は石灰化の進行にともないPTHrPの分泌量、遺伝子発現が低下して おり、PTHrPが石灰化に対して抑制的に作用していること、長期間 石灰化を誘導するとosteopontin(OPN)の遺伝子発現が增加している ことを報告した。1 $0^{99} \sim 10^{-7} \mathrm{M} 1,25(\mathrm{OH})_{2}$ Vit $\mathrm{D}_{3}(\mathrm{VitD})$ を添加し96時 間の細胞層カルシウム沈着量を測定したところ用量依存的に增加し、 同時に培養液中へのPTHrP分泌量を測定したところ用量依存的に分 泌量は滅少した。また、非石灰化条件下においてもVit Dは用量依 存的に、PTHrP分泌量を隇少させた。次に石灰化誘導時にVit Dを添 加し、同時にヒトPTHrP(1-34)を添加した時の細胞層カルシウム沈着 量を検討したところ、用量依存的に沈着量は隇少した。このことよ ク Vit Dによる石灰化抑制作用の一部は、Vit Dが直接PTHrP分泌を 抑制することによる可能性が示唆された。また、石灰化誘導時に Vit Dを添加し、24時間のOPNの遺伝子発現を検討したところ用量 依存的に発現量は增加した。【結論】石灰化実験系において、Vit Dは石灰化に对して促進的に作用する可能性が示唆された。 